MARIANA BARONI SELIM

Avaliação estrutural do osso terceiro metacarpiano equino frente à implantação de biopolímero à base de mamona 
MARIANA BARONI SELIM

\section{Avaliação estrutural do osso terceiro metacarpiano equino frente à implantação de biopolímero à base de mamona}

Dissertação apresentada ao Programa de PósGraduação em Clínica Cirúrgica Veterinária da Faculdade de Medicina Veterinária e Zootecnia da Universidade de São Paulo para a obtenção do título de Mestre em Ciências

Departamento:

Cirurgia

Área de concentração:

Clínica Cirúrgica Veterinária

Orientador:

Prof. Dr. André Luis do Valle De Zoppa

São Paulo 
Autorizo a reproduçäo parcial ou total desta obra, para fins acadêmicos, desde que citada a fonte.

DADOS INTERNACIONAIS DE CATALOGAÇAOONA-PUBLICAÇAO

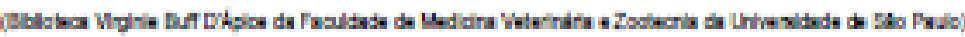

T.2005 8elim Mariane Barbel

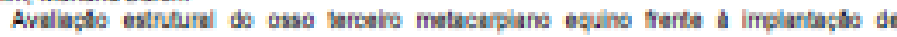
biopelimero d base de mamona $/$ Marlafa Baroni Belm. -2013 .

$122 \mathrm{t}:$ il

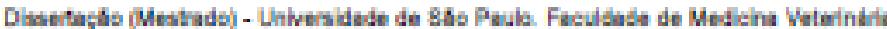
- Zootecria Depantaments de Cinurgie, 8As Paula, 2013

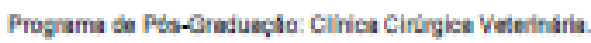

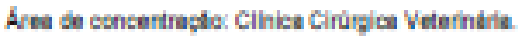

Orientader. Prot. Or. Anarb Lub do Vale De Zoppe.

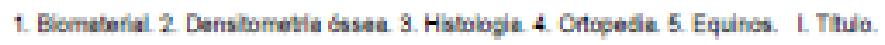




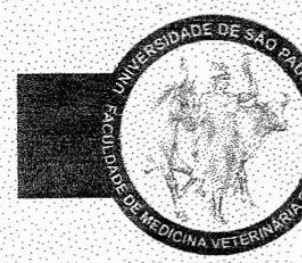

UNIVERSIDADE DE SÃO PAULO

FACULDADE DE MEDICINA VETERINARIA E ZOOTECAIA

Comissão de Ética no uso de animais

\section{CERTIFICADO}

Certificamos que o Projeto intitulado "Avaliação estrutural do osso terceiro metacarpiano equino frente à implantação de biopolímero a base de mamona", protocolado sob o $\mathrm{n}^{\circ} 2356 / 2011$, utilizando 6 (seis) cavalos, sob a responsabilidade do Prof. Dr. André Luiz do Valle De Zoppa, está de acordo com os princípios éticos de experimentação animal da "Comissão de Ética no uso de animais" da Faculdade de Medicina Veterinária e Zootecnia da Universidade de São Paulo e foi aprovado em reunião de 17/8/2011.

We certify that the Research "Structural evaluation of the equine third metacarpal bone against the implantation of biopolymer based on castor oil", protocol number 2356/2011, utilizing 6 (six) horses, under the responsibility Prof. Dr. André Luiz do Valle De Zoppa, agree with Ethical Principles in Animal Research adopted by "Ethic Committee in the use of animals" of the School of Veterinary Medicine and Animal Science of University of São Paulo and was approved in the meeting of day $8 / 17 / 2011$.

São Paulo, 3 de setembro de 2012.

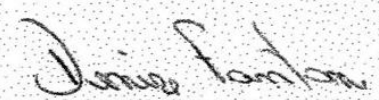

Denise Tabacchi Fantoni

Presidente 


\section{FOLHA DE AVALIAÇÃO}

Nome: SELIM, Mariana Baroni

Título: Avaliação estrutural do osso terceiro metacarpiano equino frente à implantação de biopolímero à base de mamona

Dissertação apresentada ao Programa de PósGraduação em Clínica Cirúrgica Veterinária da Faculdade de Medicina Veterinária e Zootecnia da Universidade de São Paulo para a obtenção do título de Mestre em Ciências

Data:

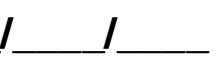

\section{Banca Examinadora}

Prof.Dr.

Instituição: Julgamento:

Prof.Dr.

Instituição: Julgamento:

Prof.Dr. Instituição: Julgamento: 


\section{DEDICATÓRIAS}

Dedico esta dissertação às pessoas que mais amo no mundo: meus pais, irmãos, avós e meu grande amor e companheiro, Lucas. Para escrever cada parágrafo deste trabalho me inspirei no que eu tenho de mais precioso na vida, na força que me motiva a sonhar e lutar pelos meus ideais: VOCÊS! 


\section{AGRADECIMENTOS}

Agradeço a Deus pela vida e por todas as oportunidades de evoluir.

Sou muito grata à minha família, principalmente aos meus pais, Carlos e Eunice, que sempre se esforçaram para dar a melhor educação aos seus três filhos. Muito obrigada por nos proporcionar uma vida confortável, repleta de amor e carinho. Aos meus irmãos, Camila e André, por sempre "pegarem no meu pé". Hoje enxergo o quanto isso foi importante para o meu amadurecimento. Aos meus cunhados, Fernando e Cristina, pelo carinho e amizade. Aos meus queridos avós, Eurico e Nancy, segundos pais, que até hoje não compreendem bem o meu trabalho na área de pesquisa, mas sempre me apoiaram e me admiraram pelas minhas realizações. À minha tia Luiza, pelos meus lanchinhos e confecções para os cavalos e para mim.

Agradeço ao meu namorado Lucas, que acompanhou de perto a minha jornada durante o mestrado, e que, devido a isso, passou do pavor à grande afinidade pelos cavalos. Sou muito grata pela compreensão nos momentos de ausência, nervosismo, cansaço e por toda atenção, amor, carinho e, acima de tudo, companheirismo nas dificuldades. Muito obrigada pelos momentos de descontração e alegria, eles tornaram os obstáculos quase imperceptíveis. Também agradeço à nova família que ganhei: Ivaldo, Deise, Denise, Benito, Neide e Vô Ciro. Obrigada por me tratarem com tanto amor e carinho, sempre me recebendo bem em seu lar!

E aos amigos... Agradeço a todos do grupo $\mathrm{C}$ da $71^{\mathrm{a}}$ turma da FMVZ USP, em especial à Carol (Bá), Carla (Gá), Ana (Baranguinha), Joyce (Muflinha) e Taís (Bruxinha). Obrigada pelo apoio e amizade desde os primeiros anos de curso, seja com dúvidas técnicas, ouvindo reclamações, choradeiras, reuniões, telefonemas, desentendimentos e sempre muitas risadas! Aos amigos de longa data: Taci, Luciana, Lucy e André Assi, sempre presentes, torcendo e vibrando comigo. E aos amigos mais recentes, como os da Casa de Goytacaz, com os quais aprendo um pouco a cada dia.

Sem esquecer da minha segunda morada, ou seria primeira? A Universidade de São Paulo, que há cerca de oito anos era apenas um sonho, aparentemente inatingível... Sou grata por todos conhecimentos adquiridos e pela realização de um sonho, que acabou se tornando muito maior do que o planejado. Do simples desejo de ser Médica Veterinária e trabalhar com cavalos, acabei me tornando Mestre. 
Agradeço a todos os envolvidos neste processo. Inicialmente ao professor André Zoppa, que desde muito cedo me abriu as portas para a área de pesquisa e de cirurgia de equinos, me orientando. Aos colegas do grupo de pesquisa: Rodrigo Romero, Luiz Fernando, Rodrigo Crispim, Guilherme, Carlos, Paolo, Fernanda e Geissiane. Dedico agradecimento especial à Fernanda, pela grande parceria e amizade, que permitiram o desenvolvimento deste estudo; e à Geissiane, pela colaboração nas atividades do projeto. À Lara, responsável por anestesiar os nossos animais. À Ana Paula Moraes, nossa ultrassonografista oficial. Às alunas de iniciação científica Joyce e Sofia, as quais tive o prazer de co-orientar e a oportunidade de aprender muito. Aos Médicos Veterinários Residentes do Hospital de Equinos da FMVZ USP (Ayrton, Cynthia, Milena, Tiago, Murilo, Paulo, Nathalia e Marina) e à estagiária Laura, pela atenção e ajuda com os nossos cavalos. Também agradeço aos enfermeiros Marcos, Cícero e Henrique, pelo auxílio com os materiais e procedimentos do projeto; e aos funcionários Rosendo, Gervásio e José Antônio pelo trato com os cavalos. À Médica Veterinária Silvana e aos funcionários Hugo, Reginaldo e Benjamin do Serviço de Diagnóstico por imagem, pela paciência e suporte com as imagens radiográficas. Ao Prof. Dr. Stefano Carlo Filippo Hagen pela contribuição na seção de diagnóstico radiográfico.

Não esquecendo de todos os professores que contribuíram para a minha formação e especialização em clínica e cirurgia de equinos e, indiretamente, para a realização deste trabalho: Drs (as). Wilson Roberto Fernandes, Raquel Yvonne Arantes Baccarin, Carla Bargi Belli, Cláudia Barbosa Fernandes, Aline Magalhães Ambrósio e Luiz Claudio Lopes Correia da Silva.

Agradeço pela confiança e co-orientação dos Profs. Drs. Luciana Correa e Vitor Alias Arana nas avaliações histológicas do experimento. $O$ agradecimento se estende às suas respectivas orientadas Flávia, Helô, Lorraine e Vivian, pelo auxílio nas atividades laboratoriais.

Ao Prof. Dr. Gilberto Chieriche e ao Rossi da empresa Poliquil por gentilmente cederem o biomaterial utilizado no projeto.

À FAPESP, pelo auxílio pesquisa; e à CAPES pela concessão da bolsa de estudos.

Por fim, agadeço aos protagonistas desta pesquisa, os cavalos Trovão, Buenacho, Ciclone, Garoa, Tufão e Chuvisco, que involuntariamente contribuíram para o desenvolvimento científico em prol da saúde e bem estar da espécie equina. 
"Na queda, levante-se.

A cada erro, corrija-se. Na luta, esforce-se.

Você faz o destino. Uma mão vigorosa sustenta seus passos.

Preencha-se de vitalidade, vontade de progredir e de conquistar a paz.

Creia no seu valor.

... Integre-se ao sábio ritmo da vida. Use de compreensão.

Esteja alegre.

O seu aprimoramento nasce na certeza da vitória"

Lourival Lopes em "Sementes de Felicidade" 


\section{RESUMO}

SELIM, M. B. Avaliação estrutural do osso terceiro metacarpiano equino frente à implantação de biopolímero à base de mamona. [Structural evaluation of the third metacarpal bone against the implantation of biopolymer based on castor oil] 2013. 122 f. Dissertação (Mestrado em Ciências) - Faculdade de Medicina Veterinária e Zootecnia, Universidade de São Paulo, São Paulo, 2013.

Uma série de novas estratégias vem sendo desenvolvidas com o objetivo de otimizar a reparação óssea, pois os métodos atualmente disponíveis em ortopedia humana e veterinária não apresentam resultados plenamente satisfatórios. Inúmeros pesquisadores dedicam-se ao desenvolvimento e estudo da compatibilidade de novos implantes com o propósito de acelerar a reparação óssea. O polímero a base de óleo de mamona tem chamado atenção para a sua aplicação como substituto ósseo, pois é um produto natural, biocompatível e com propriedades estruturais semelhantes às do tecido ósseo. Seis equinos foram submetidos à ostectomia na superfície diafisária dorsal de seus terceiros metacarpianos. Uma das falhas ósseas foi preenchida com o polímero a base de mamona e o outra, no membro contralateral permaneceu sem preenchimento, atuando como controle. Os animais foram acompanhados por um período de 120 dias após o procedimento através de monitoramento radiográfico da densidade óssea. Após este período, realizou-se biópsia para avaliação histológica por microscopias de luz e eletrônica de varredura. A densitometria óptica revelou valores médios de 14,17mmAl $\pm 1,722$ e 16,33mmAl $\pm 1,633(p=0,027)$ para os grupos polímero e controle, respectivamente. A microscopia óptica de luz demonstrou maior porcentagem de tecido ósseo neoformado no grupo controle $(50,15 \% \pm 14,83)$ quando comparado ao grupo polímero $(26,94 \% \pm 12,06)$, com $p<0,0001$. No entanto, a microscopia eletrônica de varredura permitiu observar que a qualidade do tecido ósseo formado na presença do biomaterial foi mantida. Além disso, não foram observadas reações adversas ao biomaterial, como a formação de tecido cicatricial ou reações de corpo estranho, levando a conclusão de que a poliuretana de óleo de mamona pode ser considerada adequada ao preenchimento de falhas ósseas em equinos, uma vez que desmonstrou compatibilidade e osteocondutividade.

Palavras-chave: Biomaterial. Densitometria Óssea. Histologia. Ortopedia. Equinos. 


\begin{abstract}
SELIM, M. B. Structural evaluation of the third metacarpal bone against the implantation of biopolymer based on castor oil. [Avaliação estrutural do osso terceiro metacarpiano equino frente à implantação de biopolímero à base de mamona] 2013. 122 f. Dissertação (Mestrado em Ciências) - Faculdade de Medicina Veterinária e Zootecnia, Universidade de São Paulo, São Paulo, 2013.
\end{abstract}

A series of new strategies have been developed in order to optimize bone repair, because the methods currently available for human and veterinary orthopedics have no fully satisfactory results. Many researchers have dedicated to develop and study the compatibility of new implants in order to accelerate bone repair. The polymer of castor oil have drawn attention for its application as a bone substitute because it is a natural, biocompatible and have structural properties similar to bone tissue. Six horses were submited to ostectomy on the dorsal surface of its third metacarpal bone. One of the bone defects was filled with polymer of castor oil and the other remained unfilled, as a control group. The animals were followed for a period of 120 days after the procedure by monitoring radiographic bone density. After this period, a biopsy was performed for histological evaluation by light and scanning electron microscopy. The optical densitometry revealed medium values of $14.17 \mathrm{mmAl} \pm 1.722$ and $16.33 \mathrm{mmAl} \pm 1.633(\mathrm{p}=0.027$ ) for the polymer and control groups, respectively. The light microscopy showed a higher percentage of new bone formation in the control group ( $50.15 \% \pm 14.83$ ) than in the polymer group ( $26.94 \% \pm 12.06$ ), with $p<0.0001$. However, scanning electron microscopy allowed to observe that the quality of bone formation tissue in the presence of biomaterial was maintained. Furthermore, there were no adverse reactions to biomaterial, such as scar formation or as a foreign body reaction, allowing to conclude that the polymer of castor oil can be considered suitable to fill bone defects in horses, since it demonstrated compatibility and osteoconductivity.

Keywords: Biomaterial. Bone densitometry. Histology. Orthopedics. Equine. 


\section{LISTA DE FIGURAS}

Figura 1 - Esquema de procedimentos e avaliações realizados no estudo ..............52

Figura 2 - Material utilizado para a confecção das falhas e biópsias ósseas .............53

Figura 3 - Polímero a base de poliuretana de mamona .........................................54

Figura 4 - Sequência de procedimentos para a confecção das falhas ósseas .........56

Figura 5 - Sequência de procedimentos para a confecção das falhas ósseas .........57

Figura 6 - Sequência de procedimentos para o preenchimento das falhas ósseas com o biomaterial

Figura 7 - Sequência de procedimentos para o preenchimento das falhas ósseas com o biomaterial

Figura 8 - Sequência de procedimentos de biópsia óssea de falha não preenchida com biomaterial

Figura 9 - Biópsia óssea de falha preenchida com biomaterial. 62

Figura 10 - Exame radiográfico 65

Figura 11 - Escala de alumínio utilizada para a determinação da densidade óptica radiográfica

Figura 12 - Aparelho de emissão de raios $x$ utilizado durante as avaliações radiográficas

Figura 13 - Cassete digital empregado para a aquisição das imagens radiográficas (frente e verso)

Figura 14 - Procedimentos para a determinação da densidade óptica radiográfica.. 68

Figura 15 - Procedimentos para a determinação da densidade óptica radiográfica.. 69

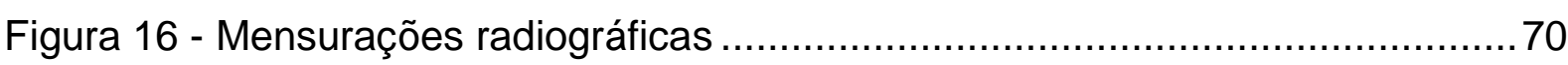

Figura 17 - Mensurações Radiográficas ......................................................... 71

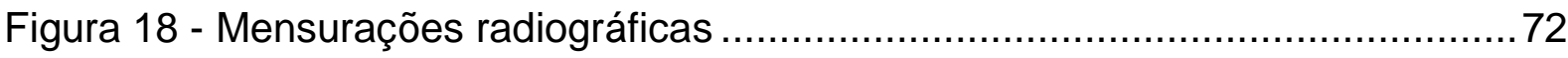

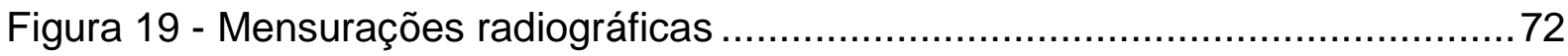

Figura 20 - Avaliação histológica por microscopia óptica de luz ..............................74

Figura 21 - Avaliação histológica por microscopia óptica de luz ................................74

Figura 22 - Evolução da densidade óptica radiográfica média, nos grupos polímero e controle, de acordo o período pós operatório - São Paulo - 2011 a 2013

Figura 23 - Fragmento ósseo coletado durante a confecção da falha óssea ............90

Figura 24 - Fragmento ósseo de biópsia do grupo controle. 
Figura 25 - Fragmento ósseo de biópsia do grupo polímero 91

Figura 26 - Fragmento ósseo de biópsia do grupo polímero 92

Figura 27 - Fragmentos ósseos coletados durante a confecção das falhas ósseas . 94 Figura 28 - Fragmentos ósseos coletados durante a confecção das falhas ósseas . 95 Figura 29 - Fragmentos do polímero de poliuretana de mamona antes da implantação no tecido ósseo equino. .96

Figura 30 Comparação entre a estrutura do biomaterial e à do tecido ósseo imaturo equino.

Figura 31 - Fragmento ósseo coletado durante a biópsia de falha não preenchida com biomaterial .....

Figura 32 - Fragmento ósseo coletado durante biópsia de falha preenchida com biomaterial. .99

Figura 33 - Fragmento ósseo coletado durante biópsia de falha preenchida com biomaterial. 100

Figura 34 - Fragmento ósseo coletado durante biópsia de falha preenchida com biomaterial. 100

Figura 35 - Fragmentos de biópsia óssea 101 


\section{LISTA DE TABELAS}

Tabela 1 - Densidade óptica radiográfica (em mmAl) das falhas ósseas preenchidas com polímero (Pol) e sem preenchimento (Cont), em diferentes momentos pós operatórios - São Paulo - 2011 a 2013 ..........................77

Tabela 2 - Diâmetro transversal das falhas ósseas aos 7 e 120 dias após o procedimento cirúrgico - São Paulo - 2011 a 2013 ...............................78

Tabela 3 - Diâmetro longitudinal das falhas ósseas aos 7 e 120 dias após o procedimento cirúrgico - São Paulo - 2011 a 2013 .79

Tabela 4 - Área das falhas ósseas aos 7 e 120 dias após o procedimento cirúrgico São Paulo - 2011 a 2013. 79

Tabela 5 - Profundidade das falhas ósseas aos 7 e 120 dias após o procedimento cirúrgico - São Paulo - 2011 a 2013 .80

Tabela 6 - Descritores da variável densidade radiográfica dos grupos polímero e controle para os diferentes momentos de coleta - São Paulo - 2011 a 2013

Tabela 7 - Descritores da variável diâmetro transversal (D Trans) nos grupos polímero (Pol) e controle (Cont) nos momentos D7 e D120 - São Paulo 2011 a 2013

Tabela 8 - Descritores da variável diâmetro longitudinal (D Long) nos grupos polímero (Pol) e controle (Cont) nos momentos D7 e D120 - São Paulo 2011 a 2013

Tabela 9 - Descritores da variável área nos grupos polímero (Pol) e controle (Cont) nos momentos D7 e D120 - São Paulo - 2011 a 2013

Tabela 10 - Descritores da variável profundidade (Prof) nos grupos polímero (Pol) e controle (Cont) nos momentos D7 e D120 - São Paulo - 2011 a 2013 .. 82

Tabela 11 - Resultados do teste de Wilcoxon entre a densidade radiográfica dos grupos polímero (Pol) e controle (Cont) nos diferentes momentos de coleta - São Paulo - 2011 a 2013

Tabela 12 - Resultados do teste de Wilcoxon da densidade radiográfica do grupo polímero (Pol) entre D0 e os demais momentos de coleta - São Paulo 2011 a 2013 
Tabela 13 - Resultados do teste de Wilcoxon da densidade radiográfica do grupo controle (Cont) entre D0 e os demais momentos de coleta - São Paulo 2011 a 2013

Tabela 14 - Resultados do teste de Wilcoxon do diâmetro transversal ( $D$ Trans) entre o grupo polímero (Pol) e o grupo controle (Cont) para os mesmos momentos de coleta, dentro de cada grupo para os diferentes momentos de coleta (D7 e D0) e entre a porcentagem de diminuição do diâmetro (\% Dim) de cada grupo - São Paulo - 2011 a 2013

Tabela 15 - Resultados do teste de Wilcoxon do diâmetro longitudinal (D Long) entre o grupo polímero (Pol) e o grupo controle (Cont) para os mesmos momentos de coleta, dentro de cada grupo para os diferentes momentos de coleta (D7 e D0) e entre a porcentagem de diminuição do diâmentro (\% Dim) de cada grupo - São Paulo - 2011 a 2013

Tabela 16 - Resultados do teste de Wilcoxon da área entre o grupo polímero (Pol) e o grupo controle (Cont) para os mesmos momentos de coleta, dentro de cada grupo para os diferentes momentos de coleta (D7 e D0) e entre a porcentagem de diminuição da área (\% Dim) de cada grupo - São Paulo - 2011 a 2013. .85

Tabela 17 - Resultados do teste de Wilcoxon da profundidade (Prof) entre o grupo polímero (Pol) e o grupo controle (Cont) para os mesmos momentos de coleta, dentro de cada grupo para os diferentes momentos de coleta (D7 e D0) e entre a porcentagem de diminuição da profundidade (\% Dim) de cada grupo - São Paulo - 2011 a 2013 ............................................. 85

Tabela 18 - Área total e de osso neoformado (Neo) nos cortes histológicos de fragmentos de biópsia óssea com preenchimento pelo biomaterial. Também é apresentada a proporção entre a área de osso neoformado e a área total de tecido - São Paulo - 2011 a 2013.

Tabela 19 - Área total e de osso neoformado nos cortes histológicos de fragmentos de biópsia óssea sem preenchimento com biomaterial. Também é apresentada a proporção entre a área de osso neoformado e a área total de tecido - São Paulo - 2011 a 2013

Tabela 20 - Descritores da variável \%Osso Neoformado (Neo) nos grupos polímero (Pol) e controle (Cont) - São Paulo - 2011 a 2013 .89 
Tabela 21 - Resultado do teste de Wilcoxon entre a \%Área Neoformada dos grupos polímero e controle - São Paulo - 2011 a 2013 ................................... 89 


\section{LISTA DE ABREVIATURAS E SIGLAS}

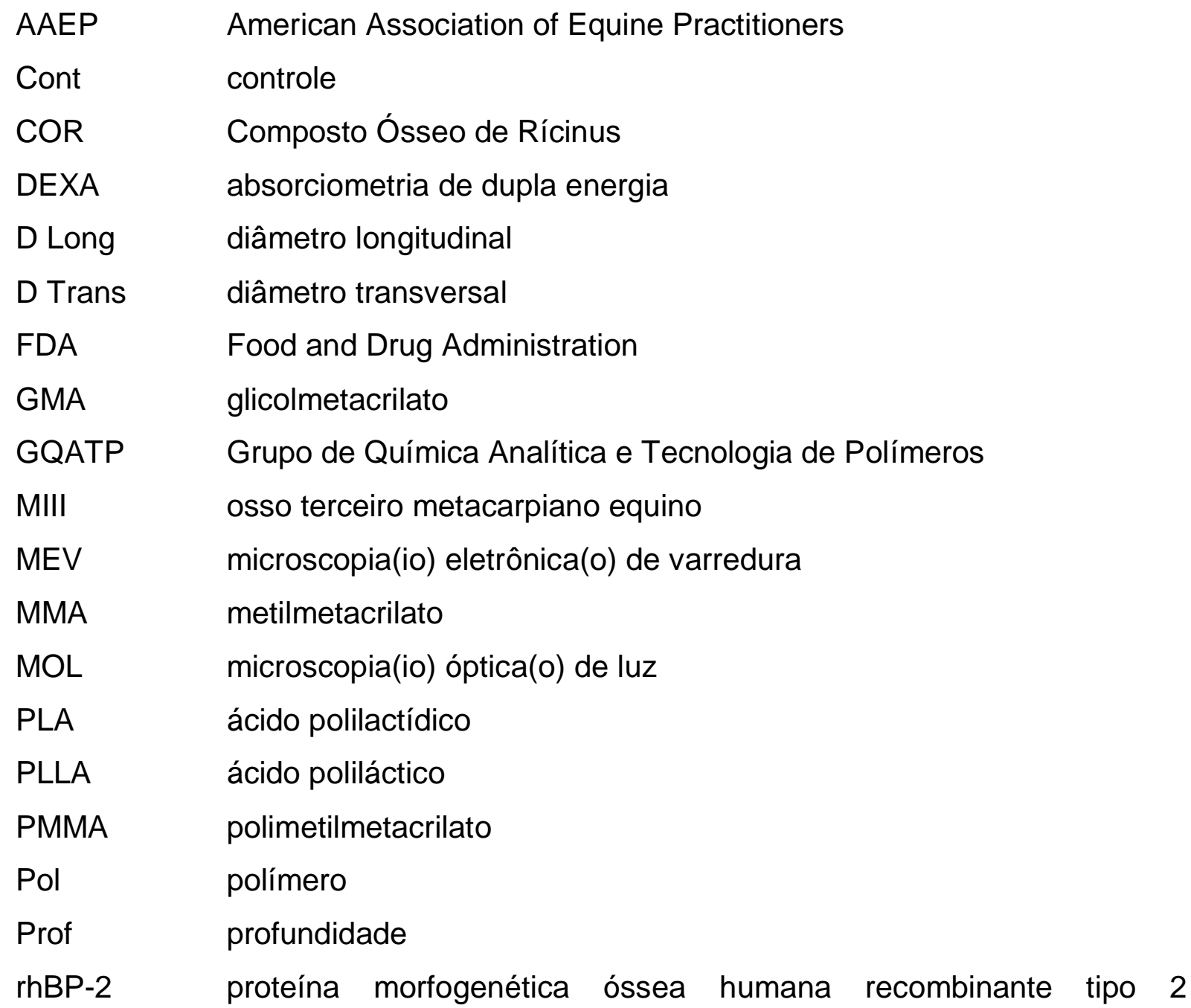




\section{LISTA DE SÍMBOLOS}

$\begin{array}{ll}\mathrm{bpm} & \text { batimentos cardíacos por minuto } \\ \mathrm{cm} & \text { centímetro } \\ \mathrm{cm}^{2} & \text { centímetro quadrado } \\ \mathrm{CO}_{2} & \text { dióxido de carbono } \\ \mathrm{g} & \text { grama } \\ \mathrm{kg} & \text { quilograma } \\ \mathrm{kV} & \text { quilovolt } \\ \mathrm{I} & \text { litro } \\ \mathrm{mmAl} & \text { milímetros de alumínio } \\ \mathrm{mAs} & \text { miliampere } \\ \mathrm{mg} & \text { miligrama } \\ \mathrm{ml} & \text { mililitro } \\ \mathrm{mm} & \text { milímetro } \\ \mathrm{mpm} & \text { movimentos respiratórios por minuto } \\ \mu \mathrm{m} & \text { micrômetro } \\ \mu \mathrm{m}^{2} & \text { micrômetro quadrado }\end{array}$




\section{SUMÁRIO}

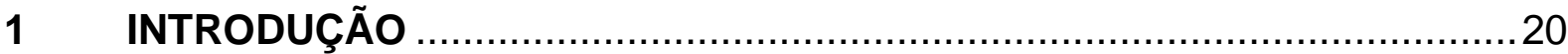

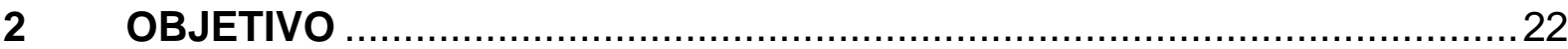

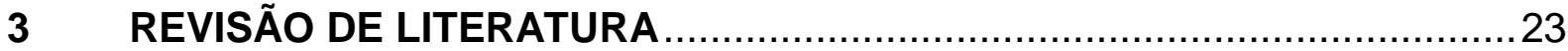

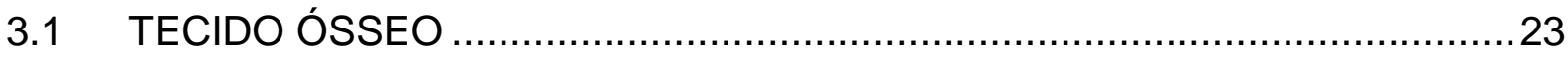

3.1.1 Definição, composição e organização ...........................................23

3.1.2 Origem, crescimento, remodelação e reparação .................................26

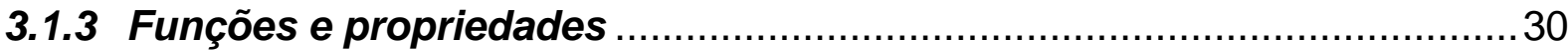

3.1.4 O osso terceiro metacarpiano equino (MIII) ...................................... 31

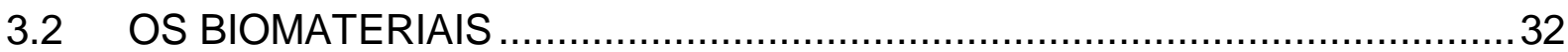

3.2.1 Biomateriais como substitutos ósseos .......................................... 33

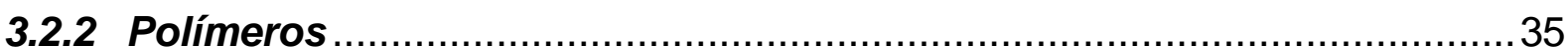

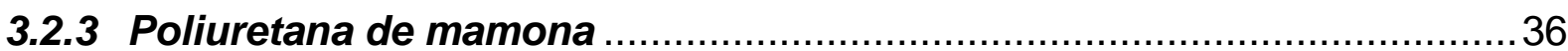

3.2.4 Os substitutos ósseos em ortopedia de equinos ............................ 38

3.3 DENSITOMETRIA ÓPTICA RADIOGRÁFICA .................................... 43

3.4 MICROSCOPIA ÓPTICA DE LUZ (MOL) ….......................................... 45

3.5 MICROSCOPIA ELETRÔNICA DE VARREDURA (MEV) $\ldots \ldots \ldots \ldots \ldots \ldots \ldots \ldots \ldots . . \ldots \ldots$

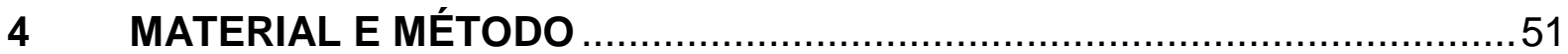

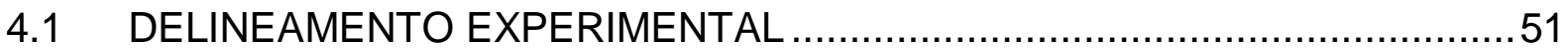

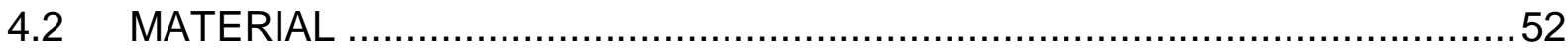

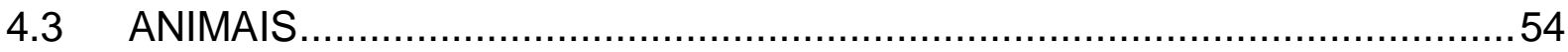

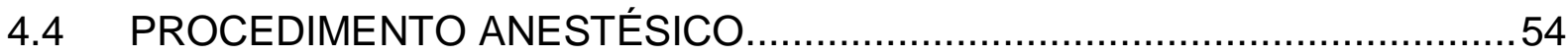

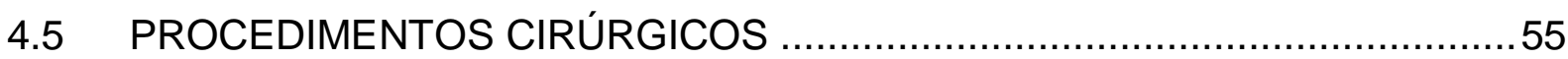

4.5.1 Falha óssea e preenchimento com polímero....................................... 55

4.5.2 Biópsia óssea ......................................................................... 60

4.6 PROCEDIMENTOS PÓS-OPERATÓRIOS ...........................................63

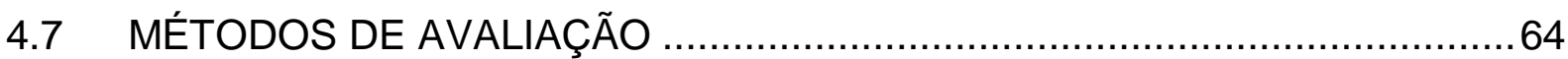

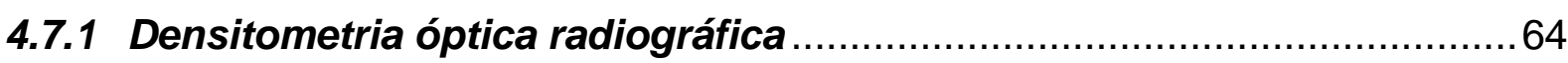

4.7.2 Avaliação por microscopia óptica de luz (MOL) ................................ 73

4.7.3 Avaliação por microscopia eletrônica de varredura (MEV) .................... 75

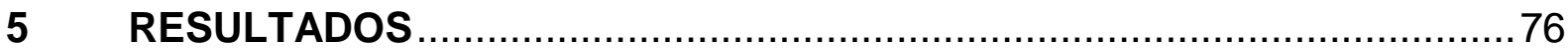

5.1 AVALIAÇÃO CLÍNICA E DE CLAUDICAÇÃO ........................................ 76

5.2 DENSITOMETRIAÓPTICA RADIOGRÁFICA E MENSURAÇÕES RADIOGRÁFICAS ... 77

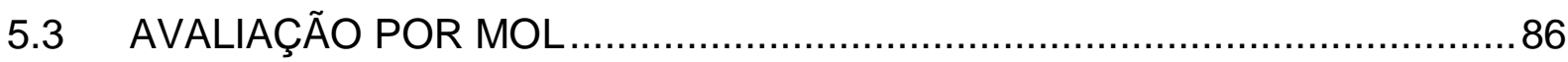

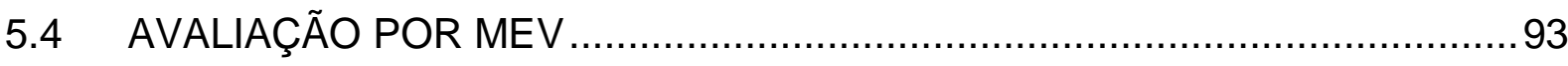




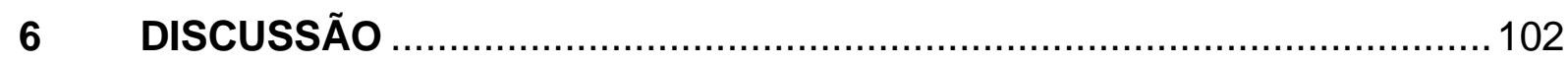

7 CONCLUSÃO

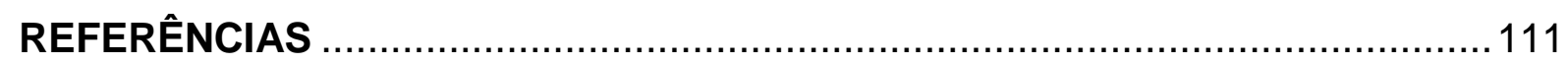

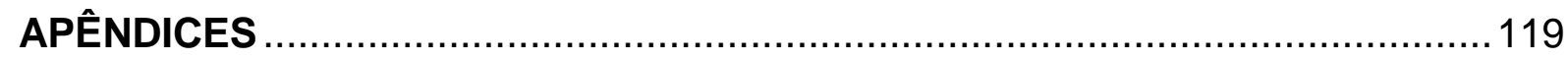




\section{INTRODUÇÃO}

Os métodos atualmente utilizados para a correção de defeitos ósseos em ortopedia humana e veterinária não apresentam resultados satisfatórios, principalmente quando se trata de defeitos extensos e irregulares, nos quais o processo de reparação resulta na formação de tecido cicatricial de qualidade inferior ao tecido original. Com base nestas informações, uma série de novas estratégias vem sendo estudadas nos últimos anos, objetivando a maximização da reparação óssea nas mais diversas situações (VERTENTEN et al., 2010).

Visando atender às necessidades acima descritas e minimizar as complicações e desvantagens advindas da utilização de enxertos ósseos autógenos, uma grande variedade de substitutos ósseos foi desenvolvida (PÉREZ-SÁNCHEZ et al., 2010). Enquadram-se na classe de substitutos ósseos os biomaterias, que devem apresentar propriedades físicas e biológicas compatíveis com os tecidos vivos hospedeiros (KAWACHI et al., 2000).

A disponibilidade de uma grande variedade de biomateriais parece ser atrativa. No entanto, ainda há poucas informações a respeito de suas propriedades e comportamento in vivo, o que dificulta a escolha do produto que mais se aproxime das características do tecido ósseo (VAN LIESHOUT et al., 2011).

O entendimento do processo de interação entre o implante e o tecido receptor é crucial para o desenvolvimento do biomaterial adequado. Na maioria dos casos, a razão para o insucesso de um implante é a falta de compatibilidade entre ele e o tecido ósseo do paciente (BEDZIN'SKI et al., 2010).

As fraturas em equinos representam desafios distintos associados ao tamanho, anatomia e locomoção do indivíduo, fatores os quais contribuem para que as técnicas reparatórias utilizadas tenham baixo índice de sucesso quando comparado a outras espécies. Mecanismos não invasivos para avaliar a qualidade da reparação e resistência ósseas são críticos ao manejo de fraturas no cavalo. Métodos para acelerar a consolidação da fratura são o objetivo de diversas pesquisas que visam reduzir complicações e melhorar as taxas de sucesso no tratamento de fraturas em equinos (LOPEZ; MARKEL, 2012).

Sabe-se que a reparação óssea nos equinos ocorre em menor velocidade que em outras espécies, como ruminantes, pequenos animais e humanos. Dessa 
maneira, qualquer tratamento que possa ser associado às tradicionais técnicas de osteossíntese e que acelere a reparação óssea deve ser considerado (LOPEZ; MARKEL, 2006).

Há poucos estudos sobre a utilização de biomateriais como substitutos ósseos em equinos, sendo que a maioria destes são relatos de caso, e raros descrevem em detalhes a interação entre o implante e o tecido receptor, bem como seus efeitos sobre a estrutura óssea (DORNBUSCH et al., 2010).

O projeto proposto visa enriquecer a escassa literatura a respeito da utilização de substitutos ósseos na espécie equina, elucidando o comportamento estrutural do tecido ósseo equino quando em contato com um biomaterial polimérico de origem vegetal. 


\section{OBJETIVO}

O presente estudo objetiva a avaliação do comportamento da estrutura óssea frente à interação com substituto ósseo a base de óleo de mamona inserido em falhas ósseas experimentais no osso terceiro metacarpiano de equinos.

Pretende-se investigar e descrever as possíveis alterações na arquitetura óssea advindas da presença do material em questão, uma vez que estas são cruciais para a determinação da qualidade do tecido neoformado. 


\section{REVISÃO DE LITERATURA}

\subsection{TECIDO ÓSSEO}

\subsubsection{Definição, composição e organização}

O tecido ósseo é um tecido conjuntivo especializado, formado por células e material extracelular calcificado, a matriz óssea (MORAES, 2008).

A matriz óssea é dividida em duas porções, a fase mineral e a matriz orgânica. A fase mineral, ou inorgânica, é constituída por fosfato de cálcio sob a forma de cristais de hidroxiapatita $\left(\mathrm{Ca}_{10}\left(\mathrm{PO}_{4}\right)_{6} \mathrm{OH}_{2}\right)$ associados a outros íons como citrato, sódio, magnésio, flúor e cloreto. A matriz orgânica é constituída por $90 \%$ de colágeno (dos tipos I - principalmente, III e V) e 10\% de componentes não colágenos (proteínas, na grande maioria - osteopontina, sialoproteína óssea, osteonectina, osteocalcina, ente outras), os quais se associam às fibrilas colágenas, outorgando à matriz as características especiais que fazem com que esta mineralize e mantenha a fase mineral confinada (ARANA; BRADASCHIA, 2012).

Dois grupos de células estão presentes no tecido ósseo: as relacionadas com a formação e mineralização da matriz, e as relacionadas com a sua reabsorção. As células indiferenciadas de origem mesenquimal são induzidas a se diferenciarem em osteoblastos, que são células sintetizadoras e secretoras dos elementos da matriz óssea orgânica. Alguns osteoblastos permanecem rodeados pela matriz óssea, ficando alojados em lacunas conectadas por finos canalículos, sendo então chamados de osteócitos. Em períodos de repouso, quando os osteoblastos da superfície óssea param de secretar matriz orgânica, estes se tornam achatados, recobrindo a última camada de matriz orgânica secretada (osteóide), denominandose, então, células de revestimento ósseo. Já as células envolvidas na reabsorção óssea provém da fusão de células da linhagem monocítica do sangue, e são chamadas de osteoclastos. As células ósseas interagem entre si, sendo as atividades osteocláticas e osteoblásticas interdependentes (ARANA; KATCHBURIAN, 2004). 
A matriz óssea mineralizada é coberta por duas "membranas" não calcificadas de natureza conjuntiva, que possibilitam a gradual relação entre 0 tecido mineralizado e o restante do organismo. Recobrindo a superfície óssea externa está o periósteo, constituído por uma camada superficial fibrosa espessa que contém fibras colágenas, fibroblastos e escassas fibras elásticas; e por uma camada profunda, formada por células de revestimento ósseo e células indiferenciadas. No periósteo ativo, envolvido em fenômenos de reparação e remodelação, a camada de células indiferenciadas é bastante evidente, contendo diversas células em proliferação e que, posteriormente, diferenciam-se em osteoblastos (MORAES, 2008).

O periósteo reveste toda a superfície óssea com exceção da cartilagem articular e sítios de inserção muscular. Além disso, possui grande quantidade de fibras sensitivas, vasos sanguíneos e linfáticos, os quais têm a função de aumentar a atividade metabólica dos ossos. Dessa maneira, as principais funções desempenhadas pelo periósteo estão relacionadas ao crescimento e remodelamento ósseo (KÖNIG; LIEBICH, 2002).

Revestindo as superfícies internas do osso, isto é, as cavidades de osso esponjoso, canais de Havers e de Volkman do osso compacto e as cavidades medulares, encontra-se o endósteo. Trata-se de uma camada contínua e geralmente única de osteoblastos/células de revestimento ósseo com características semelhantes às do periósteo. Entretanto, o endósteo apresenta maior atividade que o periósteo e, na maioria das vezes, as suas células de revestimento estão exercendo função de formação óssea, estando, portanto, diferenciadas em osteoblastos. Por vezes, a continuidade dessa camada é interrompida por osteoclastos envolvidos na função de reabsorção (BANKS, 1991).

O periósteo e o endósteo asseguram não apenas a separação entre osso e as estruturas adjacentes, mas também a manutenção de um ambiente distinto em composição iônica, quando comparado ao restante do líquido extracelular e ao plasma sanguíneo (ARANA; KATCHBURIAN, 2004).

Ao observar um corte de osso macroscopicamente, verifica-se que ele apresenta dois padrões estruturais distintos: um com diversas trabéculas e cavidades intercomunicantes, denominado de osso esponjoso ou trabecular; e outro sem cavidades e trabéculas, chamado de osso compacto ou cortical. Tal classificação é macroscópica, e não histológica, pois tanto o tecido compacto quanto 
o trabeculado possuem a mesma composição e estrutura histológica básica (MORAES, 2008).

Os ossos são comumente divididos, segundo sua forma e função, em quatro classes: ossos longos, curtos, planos e irregulares. Cada osso longo consiste de um corpo e duas extremidades. O corpo é conhecido como diáfise e as extremidades como epífises (SISSON; GROSSMAN, 1986).

As epífises dos ossos longos são formadas por osso esponjoso recoberto por uma delgada camada de osso compacto. A diáfise é predominantemente composta por osso compacto, com pequena quantidade de osso esponjoso na sua porção mais profunda, delimitando o canal medular. Já os ossos curtos, possuem centro esponjoso, sendo recobertos em toda sua periferia por uma camada compacta. Nos ossos planos há duas camadas de osso compacto, as superfícies interna e externa, separadas por osso esponjoso que, neste caso específico, recebe o nome de díploe (MARKEL, 1996).

As cavidades do osso esponjoso e o canal medular dos ossos longos são preenchidos pela medula óssea. Em indivíduos jovens, toda a medula óssea apresenta coloração avermelhada devido ao seu alto teor de hemácias, e encontrase intensamente ativa na produção de células sanguíneas (medula óssea hematógena). Com o passar dos anos, a medula vai sendo infiltrada por tecido adiposo, apresentando diminuição da sua atividade hematógena, dando lugar a chamada medula óssea amarela (MARKEL, 1996).

Do ponto de vista histológico, existem dois tipos de tecido ósseo: o imaturo ou primário; e o maduro, secundário ou lamelar. Ambos possuem as mesmas células e constituintes da matriz, diferindo apenas com relação à disposição espacial destes elementos (MORAES, 2008).

O tecido primário é o que se forma inicialmente, tanto durante 0 desenvolvimento embrionário quanto na reparação de fraturas. Este é temporário e substituído gradativamente por tecido secundário. Suas fibras colágenas se dispõem irregularmente, sem orientação definida, apresenta menor quantidade de minerais (mais facilmente penetrado pelos raios no exame radiográfico) e maior proporção de osteócitos quando comparado ao osso maduro. É pouco frequente em indivíduos adultos, persistindo apenas próximo às suturas dos ossos cranianos, alvéolos dentários e alguns pontos de inserção de tendões (BANKS, 1991). 
tecido secundário é a variedade geralmente encontrada nos adultos. Sua principal característica é a organização de suas fibras colágenas em lamelas, que posicionam-se paralelas umas às outras ou em camadas concêntricas em torno de canais vasculares, constituindo os sistemas de Havers ou ósteons (MORAES, 2008).

Cada sistema de Havers é um cilindro longo, às vezes bifurcado, paralelo à diáfise e formado por quatro a vinte lamelas ósseas concêntricas. No interior do cilindro há um canal revestido por endósteo, o qual abriga vasos sanguíneos e, ocasionalmente, fibras nervosas. Os canais de Havers comunicam-se por meio de canais transversais ou oblíquos, denominados de canais de Volkman. Tais canais distinguem-se dos de Havers por não apresentarem lamelas ósseas concêntricas (MORAES, 2008).

O tecido ósseo é altamente dependente de vascularização. Apesar de o periósteo conter grande quantidade de vasos sanguíneos, poucos canais vasculares se originam através dele para o interior do osso compacto. A vascularização de cada osso longo geralmente ocorre através de um canal único pelo qual penetram arteríolas e saem vênulas. Estes vasos principais se ramificam na medula óssea e, a partir das cavidades medulares se origina a maioria dos finos capilares contidos nos canais vasculares. Diferentemente, as fibras nervosas presentes no osso compacto se originam através do periósteo, alcançando o interior da cavidade medular por meio de ramificações. No entanto, elas raramente estão presentes dentro dos canais de Havers (ARANA; BRADASCHIA, 2012).

\subsubsection{Origem, crescimento, remodelação e reparação}

O processo pelo qual o tecido ósseo se desenvolve é chamado de ossificação ou osteogênese, e pode ocorrer a partir de uma região condensada de natureza conjuntiva ou pela substituição de um molde cartilaginoso preexistente. Pelas suas características, esses dois processos foram denominados, respectivamente, ossificação intramembranosa e endocondral (ARANA; KATCHBURIAN, 2004).

A ossificação intramembranosa é um processo característico, porém não exclusivo, de formação do complexo cranio-facial. A partir dele são formados os ossos do crânio, maxila, mandíbula, osso nasal, palatino, esfenóide e clavícula. 
Contribui também para o crescimento dos ossos curtos e para o aumento da espessura dos ossos longos (ARANA; KATCHBURIAN, 2004).

Inicialmente, em sítios de tecido mesenquimal, ocorre a proliferação de células que se agrupam e diferenciam-se, dando origem a regiões de tecido conjuntivo condensado de aspecto membranoso, formando "membranas ósseas" ou centros de ossificação. Posteriormente, as células mesenquimais são ativadas e diferenciadas em células osteogênicas ou pré-osteoblastos, que por sua vez, diferenciam-se em osteoblastos e dão início à síntese e secreção de matriz orgânica. Durante a secreção da matriz orgânica e sua subsequente mineralização, alguns osteoblastos ficam englobados na matriz calcificada, transformando-se em osteócitos (SISSON; GROSSMAN, 1986).

A confluência de diversos centros de ossificação intramembranosa resulta no entrelaçamento de algumas trabéculas ósseas que contém, entre elas, amplas cavidades com numerosos vasos sanguíneos. Desta forma, é originado o osso primário, que com o aparecimento dos osteclastos, é gradualmente substituído por osso secundário (SISSON; GROSSMAN, 1986).

A ossificação endocondral é a principal responsável pela formação dos ossos longos das extremidades, bem como das vértebras e das costelas. Nela, células mesenquimais proliferam, condensam e diferenciam-se em condroblastos. Através do processo de condrogênese é formado um molde de cartilagem hialina com o formato do futuro osso (KÖNIG; LIEBICH, 2002).

A partir da região mediana do molde cartilaginoso, células mesenquimais adjacentes ao pericôndrio se diferenciam em osteoblastos e passam a secretar matriz orgânica. Tal matriz é mineralizada na sequência, formando uma espécie de cilindro ósseo externamente ao pericôndrio do molde cartilaginoso (KÖNIG; LIEBICH, 2002).

A mineralização da matriz é acompanhada da morte de células, sendo que restam apenas os "alicerces" da matriz cartilaginosa calcificada. Vasos e células indiferenciadas penetram na região interna e central do modelo cartilaginoso, enquanto que o osso primário formado ao redor sofre processo de remodelação. As células que adentraram o molde diferenciam-se em osteoblastos e secretam matriz óssea orgânica sobre os "alicerces" de cartilagem calcificada. Dessa maneira, formase tecido ósseo nos locais onde havia tecido cartilaginoso sem que ocorra a 
transformação de cartilagem em osso, como às vezes é erroneamente interpretado (ARANA; KATCHBURIAN, 2004).

A ossificação endocondral é responsável pelo crescimento dos ossos longos em comprimento. Em tais ossos, após a progressão do processo de ossificação endocondral desde a região central dirigindo-se para as extremidades, são estabelecidas duas regiões localizadas no limite entre a diáfise e as epífises, conhecidas como discos epifisários. Os discos epifisários se mantêm ativos até o término do crescimento do indivíduo (ARANA; KATCHBURIAN, 2004).

O crescimento dos ossos consiste na formação de tecido ósseo novo, associada à reabsorção parcial de tecido já formado. A esse fenômeno dá-se o nome de remodelação, e a partir dele os ossos são capazes de manter a sua forma enquanto crescem (MORAES, 2008).

A remodelação óssea não ocorre somente durante o crescimento. Algumas áreas são reabsorvidas, enquanto outras são neoformadas de maneira alternada durante toda a vida. Isso ocorre devido à necessidade de adaptação do osso à função, aos estímulos, principalmente locais, e à necessidade de renovar pequenas áreas eventualmente microfraturadas pelos impactos. $\mathrm{O}$ desequilíbrio deste mecanismo gera desordens como a osteoporose, em que a atividade de reabsorção é maior que a de neoformação, resultando na diminuição da massa óssea com consequente queda em sua resistência, predispondo à ocorrência de fraturas (ARANA; BRADASCHIA, 2012).

Quando acometido por lesões (fraturas), o tecido ósseo possui uma habilidade única de reparação própria sem a formação de cicatrizes (LOPEZ; MARKEL, 2012).

A consolidação das fraturas pode ser de dois tipos: primária ou direta, por remodelação interna; ou secundária ou indireta, por formação de calo. A primeira ocorre somente quando há estabilidade absoluta da região acometida, e trata-se de um processo de remodelação óssea osteonal. A segunda ocorre quando há estabilidade relativa, e é muito semelhante ao processo de osteogênese, podendo estar presentes a ossificação intramembranosa e a endocondral (ITO; PERREN, 2009).

O processo de consolidação pode ser dividido em quatro estágios: inflamação, formação de calo fibroso, formação de calo rígido e remodelação (ITO; PERREN, 2009). 
A fase inflamatória tem início imediatamente após a ocorrência da lesão e dura até que se inicie a formação de tecido fibroso, cartilagem ou osso. Inicialmente ocorre a formação de um hematoma e exsudação locais a partir dos vasos sanguíneos seccionados. Há grande liberação de citocinas, migração e proliferação de células inflamatórias, as quais são responsáveis pela gradual substituição do hematoma por tecido de granulação. Também ocorre a ativação de osteoclastos, que se encarregam de remover o tecido ósseo desvitalizado da região (ITO; PERREN, 2009).

Após a inflamação, inicia-se a formação do calo fibroso, em que ocorre a migração de células osteoprogenitoras a partir do periósteo com sua posterior diferenciação em osteoblastos. Os osteoblastos promovem 0 crescimento intramembranoso, secretando matriz óssea orgânica, substituindo lentamente o hematoma pelo calo fibroso. Nessa fase também ocorre neovascularização da região, acompanhada de diferenciação de células mesenquimais em fibroblastos ou condrócitos, que também iniciam sua atividade secretora e contribuem para a composição do calo (ITO; PERREN, 2009).

Quando as extremidades ósseas forem unidas pelo calo fibroso, começa o estágio de formação do calo rígido. À medida que prossegue a ossificação intramembranosa, o tecido fibroso do interior do calo sofre ossificação endocondral, e o calo é gradualmente convertido em tecido ósseo primário. A ponte óssea inicial é formada externamente, ou dentro do canal medular, afastada da cortical original. Então, por ossificação endocondral, o tecido fibroso no traço da fratura é substituído por osso primário que, eventualmente, se une à cortical original (ITO; PERREN, 2009).

O estágio de remodelação começa uma vez que a fratura esteja unida firmemente por tecido ósseo imaturo, o qual será gradualmente reabsorvido e substituído por tecido ósseo secundário. Este estágio pode durar de meses a anos, e prossegue até que o osso retorne à sua morfologia original (ITO; PERREN, 2009). 


\subsubsection{Funções e propriedades}

Dentre as funções do tecido ósseo, podemos dizer que este constitui um suporte rígido no qual se ancoram e alojam as mais distintas estruturas orgânicas; atua na proteção de determinados órgãos e vísceras vulneráveis e determina os pontos fixos a partir dos quais o sistema locomotor gera o movimento. Além disso, os ossos são o receptáculo do tecido hematopoiético e sítio de armazenamento mineral do organismo (RÍOS-DÍAZ et al., 2008).

Ao suportarem carga durante a sustentação e locomoção, os ossos sofrem a ação de complexos padrões de força, os quais geram deformações em sua estrutura (CARTER; SPRENGLER, 2002). Em resposta à deformação, a formação óssea ajusta-se, por meio da atividade metabólica, ao mecanismo estático exigido. Cada osso se submete a procedimentos adaptativos de remodelamento de acordo com as forças as quais é submetido (KÖNIG; LIEBICH, 2002).

A capacidade de um osso resistir às forças mecânicas não depende somente da quantidade de tecido ósseo, mas sim de sua qualidade (MARTIN; CORREA, 2010). Segundo Bouxsein (2003), a qualidade óssea pode ser definida como o conjunto de características que influencia a capacidade do osso de resistir a lesões. Ela é determinada pelas propriedades estruturais e materiais, as quais por sua vez são fortemente influenciadas pelo processo de remodelamento ósseo (MARTIN; CORREA, 2010).

As propriedades estruturais do osso incluem a sua geometria (tamanho e forma) e microarquitetura (arranjo trabecular e espessura/porosidade cortical); enquanto que as propriedades materiais do osso estão relacionadas à sua composição mineral e de colágeno, bem como à presença, quantidade, tamanho e localização de microlesões (FELSENBERG; BOONEN, 2005).

A geometria óssea afeta a sua distribuição de massa, a qual por sua vez interfere na habilidade do osso em resistir à forças de tensão e torção (FELSENBERG; BOONEN, 2005). Neste cenário, o diâmetro externo e a espessura da camada cortical desempenham papel crucial na determinação da resistência óssea (MARTIN; CORREA, 2010).

Considerando a microarquitetura óssea, temos dois tipos de distribuição igualmente importantes: a do osso compacto e a do esponjoso. No osso compacto, o 
parâmetro mais relevante é a sua porosidade, enquanto que no osso esponjoso trata-se do tamanho, forma, conectividade e orientação de suas trabéculas (COMPSTON, 2006).

Com relação às propriedades materiais do tecido ósseo, foi citado anteriormente que este é composto por componentes celulares e matriz (mineral e orgânica - colágena). Em ossos normais, há evidências de que a fase mineral promova rigidez e resistência ao osso, ao passo que a matriz orgânica proporciona elasticidade e capacidade de absorção de energia. Dessa forma, o grau de mineralização da matriz exerce papel fundamental na qualidade óssea (COMPSTON, 2006).

Os ossos recebem cargas cíclicas repetitivas que resultam em danos por fadiga, os quais são expressos através de microfissuras ou microlesões. Vários estudos demonstraram que o acúmulo de pequenos danos enfraquece o osso como um todo. No entanto, também acredita-se que os microdanos sejam gatilhos para o início da remodelação. Por outro lado, o acúmulo de microlesões pode resultar no aumento da mineralização secundária e supressão de remodelação, tornando os ossos mais susceptíveis à fraturas (MARTIN; CORREA, 2010).

\subsubsection{O osso terceiro metacarpiano equino (MIII)}

Três ossos metacarpianos estão presentes no cavalo. Somente um deles, o terceiro ou metacarpiano principal é completamente desenvolvido; os outros dois, o segundo e o quarto, são muito reduzidos e comumente denominados pequenos metacarpianos ou metacarpianos acessórios. O terceiro metacarpiano é um osso longo e muito forte, que se situa verticalmente entre o carpo e a falange proximal (SISSON; GROSSMAN, 1986).

O MIII é um dos mais potentes ossos do esqueleto equino. Sua substância compacta é especialmente espessa dorsal e medialmente. A cavidade medular estende-se mais, para ambas as extremidades, do que na maioria dos ossos longos do cavalo e, deste modo, existe menos substância esponjosa (SISSON; GROSSMAN, 1986). 
O MIII tem sido visto como uma região de particular interesse devido ao grande número de lesões ao qual está sujeito (SELTZER, 1996), em resposta à sua localização distal e pelo fato de que há pouco tecido mole recobrindo e protegendo-o (BERTONE, 2006). As fraturas de terceiro metacarpiano são as lesões mais observadas em cavalos atletas. Ele é o osso do esqueleto apendicular que mais suporta cargas e, portanto, torna-se vulnerável tanto a lesões agudas como àquelas por fadiga repetitiva e cíclica (LOPEZ; MARKEL, 2006).

\subsection{OS BIOMATERIAIS}

A definição de biomaterial, de acordo com um consenso de especialistas da área, é de que eles são materiais utilizados em dispositivos destinados a interagir com sistemas biológicos (RATNER et al., 2013).

O êxito na aplicação de um biomaterial depende essencialmente de dois fatores: sua biofuncionalidade e sua biocompatibilidade. A biofuncionalidade está diretamente relacionada à capacidade do material desempenhar a função para a qual foi desenvolvido. A biocompatibilidade trata-se do estado de mútua existência entre o material e o ambiente fisiológico, sem que ele exerça efeito desfavorável sobre o mesmo (DALAPICULA et al., 2006 e GUTIERRES et al., 2006).

Os biomateriais são usualmente classificados de acordo com sua origem, mecanismo de ação e comportamento biológico (DALAPICULA, 2006).

Quanto à sua origem, podemos citar os materiais autógenos, obtidos a partir de tecido do próprio indivíduo; homógenos, que contém tecido de outro indivíduo da mesma espécie; heterógenos ou xenógenos, os quais são compostos por tecido proveniente de outra espécie; e aloplásticos, que são dispositivos de origem sintética (MORAES et al., 2004 e DALAPICULA, 2006).

Quanto ao mecanismo de ação, considerando-se os substitutos ósseos, os biomateriais podem ser osteogênicos, osteocondutores ou osteoindutores (DALAPICULA, 2006). Tais conceitos serão definidos e detalhados no tópico 3.2.1 Biomateriais como substitutos ósseos, sobre substitutos ósseos.

Com relação ao comportamento biológico dos biomateriais, eles são classificados como bioinertes, biotolerados, bioativos e bioabsorvíveis. Os bioinertes 
não provocam reações no organismo receptor, enquanto que os biotolerados são moderadamente aceitos, sendo geralmente envolvidos por uma cápsula fibrosa. Os materiais bioativos são aqueles que estabelecem uma ligação direta com o tecido receptor, promovendo proliferação celular. No caso dos bioabsorvíveis, eles são lentamente degradados e gradualmente substituídos pelos tecidos onde são implantados (GUTIERRES et al., 2006).

Fazem parte do grupo dos biomateriais os dispositivos de osteossíntese, como placas, parafusos e fios metálicos; e os materiais de preenchimento, representados pelos enxertos e substitutos ósseos (LEONEL et al., 2004).

\subsubsection{Biomateriais como substitutos ósseos}

Há diversas situações em que as lesões ósseas podem não ser capazes de se reparar sozinhas (LICHTE et al., 2011). Os grandes defeitos ósseos podem ter origem de processos traumáticos, congênitos ou neoplásicos e são considerados como desafio para a cirurgia reconstrutiva (DAMIEN; PARSONS, 1991). Para a reparação de tamanhas lesões é necessária a implantação de material adicional para preencher os espaços (LICHTE et al., 2011).

Numerosos materiais têm sido utilizados, porém poucos apresentam resultados satisfatórios já que a maioria resulta, em maior ou menor grau, resposta imunológica do organismo receptor (MORAES et al., 2004).

Os enxertos ósseos autógenos ainda são o método de escolha para o preenchimento de grandes perdas ósseas, mas apresentam desvantagens quando se considera a limitada disponibilidade, devido ao dano ocasionado às áreas doadoras (NUSS; VON ROCHENBERG, 2008).

Devido aos problemas relacionados com a obtenção de quantidade ideal e com a morbidade do sítio doador oriundos dos enxertos autógenos; e com a antigenicidade dos homógenos e heterógenos, uma grande variedade de materiais para preenchimento, denominados de aloplásticos, foi desenvolvida (LEONEL et al., 2004).

Os aloplásticos ou substitutos ósseos sintéticos são divididos em inorgânicos e orgânicos. Os materiais inorgânicos compreendem os metais e ligas metálicas, 
cerâmicas e biovidros; enquanto que os orgânicos são representados pelos polímeros (LICHTE et al., 2011).

Há, ainda, um terceiro grupo de substitutos ósseos, os compósitos. Trata-se da combinação de diversos tipos de materiais com o intuito de potencializar as suas propriedades físico-químicas e mecânicas (GUTIERRES et al., 2006).

Considerando a sua composição e mecanismos de ação, os substitutos ósseos podem ser classificados como osteogênicos, osteocondutores ou osteoindutores, como foi citado no item 3.2 Os Biomateriais.

Os materiais osteogênicos são aqueles que contêm células vivas com capacidade para se diferenciar e produzir tecido ósseo. Os osteocondutores atuam como arcabouço, sustentando uma estrutura por onde proliferam vasos sanguíneos que transportam os componentes necessários à formação óssea. Já os osteoindutores são capazes de atrair células mesenquimais, que mais tarde se diferenciarão em osteoblastos secretores de matriz óssea (DALAPICULA, 2006).

Como exemplos de materiais osteogênicos citam-se os enxertos autólogos e o aspirado de medula óssea. Dentre os osteocondutores podemos citar as cerâmicas, biovidros e polímeros; e dentre os osteoindutores, os alo e xenoenxertos, a matriz óssea desmineralizada e fatores de crescimento ósseo (GUTIERRES et al., 2006).

Atualmente existe no mercado uma grande variedade de materiais de enxerto, associado a um avanço crescente no desenvolvimento e aperfeiçoamento de materiais para este propósito. Os substitutos ósseos ideais devem manter a estabilidade mecânica e o volume tecidual durante as fases iniciais da cicatrização e, posteriormente, serem absorvidos e progressivamente substituídos por novo tecido ósseo através da deposição de matriz osteóide, a qual sofre mineralização na sequência (DALAPICULA, 2006).

Outras características desejáveis em um substituto ósseo são: superfície mimética à do osso, apresentando microestrutura porosa que possibilite a penetração do tecido ósseo em crescimento; taxa de reabsorção do implante igual ou semelhante à de deposição óssea, o que facilita a transferência de carga ao osso em desenvolvimento; produtos de degradação atóxicos e de fácil eliminação pelo organismo; propriedades mecânicas similares às do osso receptor e tolerância a processos de esterilização (LICHTE et al., 2011). 


\subsubsection{Polímeros}

Como o presente estudo visa avaliar a resposta do tecido ósseo na presença de um biomaterial polimérico, esta categoria será descrita de maneira mais detalhada a seguir.

Os polímeros são cadeias extensas de unidades monoméricas repetidas, unidas por ligações covalentes, com peso molecular elevado. A unidade monomérica é essencialmente constituída por ligações simples entre átomos de carbono, contendo, por vezes, átomos de nitrogênio, oxigênio, enxofre e silício. As propriedades físico-químicas destes materiais são influenciadas por vários fatores, dos quais se destacam: a composição, estrutura, peso molecular e a distribuição de tamanhos nas cadeias (HIGASHI et al., 1986).

São exemplos de polímeros utilizados em implantologia óssea os polietilenos, polipropilenos, poliuretanos, ácido polilactídico (PLA) e o polimetilmetacrilato (PMMA). Alguns implantes poliméricos podem causar respostas indesejáveis devido à liberação de monômeros tóxicos ou sensibilização alérgica (AFONSO, 1998).

Os polímeros de poliuretana, por apresentarem resistência mecânica à deformação e ruptura, resistência à abrasão e inatividade química, têm experimentado um crescente aumento nas aplicações como biomaterial. Eles são formados pela combinação de duas unidades químicas diferentes (poliol e diisocianato) que se alternam na cadeia (JACQUES et al., 2004).

Os materiais poliméricos estão sujeitos a fenômenos de biodegradação que dependem de sua composição química, dos monômeros residuais e dos aditivos aceleradores da polimerização (GALANTE et al., 1991). Tais fenômenos podem ocorrer em zonas localizadas das cadeias poliméricas, dando origem à dissolução, deformação e fratura de componentes (AFONSO, 1998).

A utilização de materiais poliméricos é mais vantajosa quando comparada aos metálicos, pois a diferença no módulo de elasticidade entre o implante e o osso é reduzida, o que diminui a tensão de contato e, por consequência, minimiza a reabsorção óssea. Além disso, os polímeros são passíveis de degradação, o que elimina a necessidade de uma segunda intervenção cirúrgica para remover o implante. Contudo, os conhecimentos sobre as reações adversas aos produtos de sua degradação ainda são restritos. A utilização destes materiais é restrita a 
situações de solicitações mecânicas pouco intensas, devido a limitações na sua resistência (AFONSO, 1998).

\subsubsection{Poliuretana de mamona}

A poliuretana derivada do óleo de mamona (Ricinus communis) possui fórmula molecular que tem demonstrado compatibilidade com os tecidos vivos, apresentando aspectos favoráveis de processabilidade, flexibilidade de formulação, baixa temperatura de polimerização, excelentes propriedades estruturais, ausência de emissão de vapores tóxicos, bom poder de adesão e baixo custo (JACQUES et al., 2004).

Em 1984, o Grupo de Química Analítica e Tecnologia de Polímeros (GQATP), do Instituto de Química de São Carlos da Universidade de São Paulo, coordenado pelo Prof. Dr. Gilberto Orivaldo Chieriche, iniciou pesquisas para o desenvolvimento de polióis e pré-polímeros derivados do óleo de mamona para a síntese de poliuretanas. Tais produtos foram desenvolvidos com o intuito inicial de proteger cabos telefônicos subterrâneos e aéreos. A partir de então, o GQATP vem desenvolvendo materiais e pesquisas para uma ampla gama de aplicações, como isolantes térmicos e elétricos, adesivos, eletrodos, revestimento para estruturas de concreto e, inclusive biomateriais (PEREIRA, 2010).

O polímero é obtido a partir da reação química entre um pré-polímero e um poliol do tipo poliéster. O óleo de mamona é um poliéster formado por três moléculas de ácido ricinoléico, sendo que cada uma possui um grupo hidroxila no carbono 12 , propício para a polimerização por meio de ligações uretanas. Os grupos hidroxila do ácido ricinoléico reagem com os grupos isocianatos do pré-polímero difenilmetanodiisocianato para formar o polímero, que tem sido utilizado para o preenchimento de defeitos ósseos (LEONEL et al., 2003).

A poliuretana de mamona pode ser utilizada pura ou em associação com o carbonato de cálcio. A função do carbonato é fornecer íons cálcio, o que facilita a troca iônica na interface osso-resina, com incremento do mecanismo de deposição de cálcio na matriz colágena nas várias fases do processo de reparação óssea (MARIA; PADILHA FILHO; CASTRO, 2003) 
A poliuretana de mamona apresenta propriedade de osteocondutividade sem evidência de toxicidade, oferece resistência similar à do osso humano e demonstrou ter atividade bactericida (IGNÁCIO, 1995; BOLSON et al., 2005; MARIA, PADILHA FILHO, CASTRO, 2003).

O fato do polímero de mamona apresentar excelentes propriedades estruturais é de suma importância para o sucesso encontrado após a sua implantação no preenchimento de falhas ósseas. Dentre estas propriedades, pode ser citada a presença de poros irregulares em meio a sua estrutura, com o objetivo de propiciar a neoformação tecidual dentre os mesmos (LEONEL et al., 2003).

Estudos mostraram que a integração da poliuretana de mamona depende de uma série de fatores, inclusive da sua forma de preparação e a consequente apresentação física final para o implante. A polimerização do composto, dentro ou fora do sítio de implante pode gerar diferenças importantes na sua futura incorporação (JACQUES et al., 2004).

Assim, a biocompatibilidade e a possibilidade de crescimento ósseo ao redor e na porosidade da resina poliuretana de mamona abrem grandes perspectivas de utilização do material no campo ortopédico, como por exemplo, com a função de "espaçador", substituindo o emprego do enxerto ósseo nos casos de perdas ósseas (MARIA; PADILHA FILHO; CASTRO, 2003).

As propriedades das poliuretanas derivadas do óleo de mamona como biomaterial na reparação de perdas ósseas e na produção de próteses têm apresentado resultados satisfatórios em diversos estudos (PEREIRA, 2010).

Em 1999, a poliuretana derivada do óleo de mamona desenvolvida pelo GQATP foi aprovada pelo Ministério da Saúde do Brasil como biomaterial, e em Junho de 2003 passou pelos testes de aprovação da Foof and Drug Adminitration (FDA), agência do governo norte-americano responsável pela liberação de novos alimentos, medicamentos e dispositivos médicos. A aprovação pelo FDA abre as portas para o maior mercado do mundo na área de saúde e garante a visibilidade científica e comercial do produto em todo o planeta (PEREIRA, 2010). 


\subsubsection{Os substitutos ósseos em ortopedia de equinos}

Em consulta à literatura científica dos anos 2000 a respeito da utilização de substitutos ósseos em ortopedia de equinos, foram encontrados 8 artigos relacionados ao tema, sendo 4 deles publicações internacionais e 4 nacionais. Tais publicações serão apresentadas a seguir e utilizadas como base para a discussão dos resultados obtidos neste estudo.

Inicialmente serão abordados os estudos nacionais, conduzidos por Ribeiro (2003); Pyles et al. (2007); Dornbusch et al. (2010) e Varanda (2012).

Nos trabalhos desenvolvidos por Dornbusch et al. (2010) e Ribeiro (2003), foi avaliado o desempenho da poliuretana a base de óleo de mamona no preenchimento de falhas ósseas induzidas no rádio de equinos e de alvéolos dentários após exodontia, respectivamente.

Ribeiro (2003) avaliou oito equinos, machos e fêmeas, que foram submetidos à bucotomia e extração do terceiro pré-molar inferior. Durante o procedimento a cavidade alveolar foi preenchida com polímero a base de poliuretana de mamona. Os animais foram avaliados clinicamente por um período de 120 dias. Também foi realizado acompanhamento radiográfico dos animais. Após 120 dias, efetuou-se biópsia das regiões operadas. O tempo médio de cicatrização da ferida cirúrgica foi 31 dias. Radiograficamente observou-se proliferação óssea acentuada e aumento de radiopacidade no final do experimento, e o exame histológico do material que preencheu o alvéolo revelou presença de tecido ósseo compacto ou trabecular. Concluiu-se que, a poliuretana derivada da mamona é inerte e exibe excelente biocompatibilidade quando implantada no alvéolo de equinos.

Dornbusch et al. (2010) utilizaram 5 equinos hígidos, os quais foram submetidos à tranquilização e anestesia local, seguidas da indução cirúrgica de falhas ósseas nas porções distais laterais dos rádios direito e esquerdo, promovendo-se perfurações de três centímetros de profundidade com broca de oito milímetros de diâmetro. Os membros esquerdos foram preenchidos com o polímero derivado de mamona e os direitos serviram de controle, sedo mantidos sem preenchimento. Efetuou-se avaliação clínica, de claudicação e acompanhamento radiográfico dos animais após o procedimento. A avaliação radiográfica foi realizada 
aos 15, 45, 90 e 180 dias de evolução e foram estabelecidos escores para avaliar o preenchimento ósseo das falhas e esclerose perilesional.

Todos os animais apresentaram claudicação discreta de ambos os membros que persistiu na primeira semana após a cirurgia. As feridas cirúrgicas cicatrizaram sem intercorrências, observando-se maior edema e inchaço local nos membros preenchidos com polímero. Comparativamente, os exames radiográficos demonstraram melhor preenchimento ósseo nas falhas dos membros controle. A análise morfométrica da área de esclerose radiográfica não demonstrou diferenças estatísticas entre os dois grupos. Concluiu-se que o preenchimento de falhas ósseas induzidas no rádio de equinos com polímero de mamona retardou a cicatrização óssea, sob o ponto de vista radiográfico (DORNBUSCH et al., 2010).

No estudo de Pyles et al. (2007), foram comparadas duas técnicas de estabilização de fratura dos ossos sesamóides proximais de equinos. Em uma delas foram empregados parafusos bioabsorvíveis de ácido polilático (PLLA) e na outra, parafusos metálicos, ambos com 4,5mm de diâmetro. Foram utilizados oito equinos hígidos, adultos, sem raça definida, machos e fêmeas. Após avaliações clínica e radiográfica, os animais foram submetidos à osteotomia (dia D0) e osteossíntese com parafuso, conforme o grupo experimental: grupo I (quatro animais), parafuso bioabsorvível de PLLA; e grupo II (quatro animais), parafuso metálico. Após o procedimento cirúrgico, os animais de ambos os grupos foram monitorados por meio de exames físicos e radiográficos a cada 30 dias (D30, D60, D90) até o período de 120 dias (D120).

Ao exame radiográfico no $\mathrm{D} 30$, observou-se preenchimento do foco de fratura de aspecto radiopaco, porém com densidade reduzida nos animais do grupo II. Tal preenchimento às análises clínica e radiográfica apresentou qualidade superior no grupo I. No D120, observou-se, nos animais de ambos os grupos, o preenchimento do foco de fratura por tecido radiopaco, indicando a reparação da fratura em sua quase totalidade. Contudo, no grupo I, observaram-se pontos de esclerose ao redor do implante bioabsorvível e, ao exame físico, ausência de claudicação e, nos animais do grupo II, diminuição da flexão metacarpo-falangeana e claudicação de grau I (PYLES et al., 2007).

Os implantes bioabsorvíveis de PLLA mostram-se eficazes na fixação interna de fraturas induzidas dos ossos sesamóides proximais de equinos; os animais submetidos à redução da fratura com implantes bioabsorvíveis apresentaram ao final 
do experimento grau de claudicação menor quando comparados com os animais que receberam implantes metálicos. À análise radiográfica, os implantes bioabsorvíveis de PLLA possibilitaram remodelamento ósseo de melhor qualidade, quando comparados com os implantes metálicos (PYLES et al., 2007).

Em 2012, Varanda avaliou a reparação de falhas ósseas experimentais no osso 4ํㅡㄹ metacarpiano de equinos após a aplicação de preparado de células tronco mesenquimais provenientes da medula óssea. Apesar de as células tronco não serem consideradas um substituto ósseo propriamente dito, tal estudo será descrito e utilizado como modelo comparativo, uma vez que este biomaterial foi utilizado com o intuito de melhorar a reparação óssea em equinos; e também porque alguns aspectos de seu delineamento se assemelham bastante ao presente trabalho.

Foram utilizados 5 equinos hígidos, sem raça definida, com idades entre 2,5 e 10 anos. Após confecção de falha óssea nos ossos 4ํㅜㄹ metacarpianos com cinzel e martelo, injetou-se o aspirado de medula nas áreas afetadas. Um dos membros foi mantido como controle, e o outro preenchido com o aspirado. Os animais foram avaliados clinicamente e através radiografias a partir do dia 7 , semanalmente até 0 dia 56; e a cada 28 dias até o dia 140. A partir das imagens radiográficas determinou-se a densidade óssea e o preenchimento das falhas através de escore subjetivo (VARANDA, 2012).

Nenhum dos equinos apresentou claudicação ao passo após indução das falhas e tratamento com as células tronco. Observou-se maior escore de preenchimento e densidade nos membros tratados com o aspirado. Concluiu-se que a terapia com células tronco se mostrou eficaz para o estímulo da osteogênese, acelerando o processo de reparação óssea e aumentando a quantidade de matriz óssea mineralizada no grupo tratado (VARANDA, 2012).

Considerando as publicações internacionais, Kawcak et al. (2000); Vlaminck et al. (2008); Perrier et al. (2008) e Cohen et al. (2012) investigaram a interação do tecido ósseo equino com diferentes biomateriais.

Kawcak et al. (2000) compararam a reparação óssea em falhas induzidas em costelas de equinos preenchidas com matriz óssea desmineralizada equina ou enxerto autólogo esponjoso.

Avaliou-se 8 cavalos adultos, os quais foram submetidos a ostectomias circulares de $19 \mathrm{~mm}$ em suas quartas e sextas costelas, totalizando 4 falhas ósseas. Aleatoriamente, uma das falhas foi preenchida com a matriz desmineralizada, outra 
com o enxerto autólogo e a terceira foi mantida sem preenchimento. A quarta falha foi tratada também aleatoriamente, podendo ser preenchida com qualquer um dos biomateriais ou permanecer como controle. Dessa forma, todos os cavalos receberam todos os tratamentos possíveis (KAWCAK et al., 2000).

Decorridos 56 dias após o procedimento cirúrgico, os animais foram submetidos à biópsia das regiões operadas. Foram coletados segmentos de aproximadamente $8 \mathrm{~cm}$ de cada costela, os quais incluíam os sítios de implante. Tal material foi avaliado para determinação da densidade óssea por exame radiográfico de dupla energia; segmentado e destinado à avaliação histológica de cortes descalcificados e também dosagem de cinzas, cálcio e fósforo (KAWCAK et al., 2000).

Com relação à região fraturada, todas as amostras foram classificadas como não consolidadas aos 56 dias de evolução. Não houve diferença significativa entre os grupos quanto à densidade mineral, sinais radiográficos e histológicos de reparação óssea. Os defeitos tratados com o enxerto autólogo apresentaram maiores teores de cinzas e cálcio do que os tratados com a matriz desmineralizada. A matriz desmineralizada não desencadeou reações inflamatórias e o remodelamento na sua presença ocorreu ao seu redor e no interior dos canais vasculares das partículas descalcificadas. Concluiu-se que as baixas porcentagens de cinzas e de cálcio nas amostras tratadas com matriz mineralizada podem deverse ao fato do remodelamento ocorrer a partir das regiões periféricas ao implante. Assim sendo, o mesmo atua como um obstáculo, atrasando a mineralização. Os autores não recomendam a utilização da matriz desmineralizada para acelerar ou incrementar a reparação óssea na espécie equina (KAWCAK et al., 2000).

Em estudo semelhante ao de Ribeiro (2003), Vlaminck et al. (2008) investigaram a osteointegração de um substituto ósseo sintético comercial no preenchimento de alvéolos dentários de equinos após exodontia.

Cinco pôneis adultos foram submetidos à exodontia bilateral do dente $4^{\circ}$ prémolar maxilar, seguida do preenchimento de uma das cavidades alveolares com o biomaterial. A outra foi mantida como controle. Um ano após o implante foram coletadas biópsias das regiões operadas para avaliação histológica e determinação do volume e da densidade óssea por micro tomografia computadorizada (VLAMINCK et al., 2008). 
Observou-se que o volume e a densidade óssea foram maiores no grupo controle quando comparados ao grupo tratado com o substituto ósseo. No entanto, o biomaterial apresentou excelente biocompatibilidade e osteocondutividade, que resultou em contínua deposição óssea e remodelamento das áreas preenchidas. Os autores concluíram que o material foi bem incorporado pelo tecido alveolar de equinos, mas sugerem mais estudos para investigar os benefícios do mesmo na fixação de implantes de coroa, com o objetivo de promover a reabilitação completa da arcada dentária (VLAMINCK et al., 2008).

Perrier et al. (2008) compararam a eficácia de um cimento ósseo ou matriz de fosfato acrescido de proteína morfogenética óssea humana recombinante tipo 2 (rhBMP-2), com enxertos autógenos de osso esponjoso em falhas ósseas induzidas nos ossos $2^{\circ}$ e $4^{\circ}$ metatarsianos de equinos.

Nove equinos adultos e hígidos foram submetidos à ostectomia na região proximal dos ossos $2^{\circ}$ e $4^{\circ}$ metatarsianos com serra oscilatória. Doze falhas foram mantidas sem preenchimento, 11 receberam enxerto ósseo esponjoso autólogo e 12 receberam a rhBMP-2 em matriz ou cimento de fosfato de cálcio. Após o procedimento, os animais foram acompanhados clinicamente por 12 semanas. Avaliações radiográficas foram efetuadas a cada duas semanas durante este período. Posteriormente as imagens foram classificadas subjetivamente quanto ao grau de preenchimento das lesões. Ao final do estudo os animais foram eutanasiados para a coleta de amostras das regiões operadas, as quais foram submetidas à ensaios biomecânico e avaliação histológica (PERRIER et al., 2008).

Observou-se que o preenchimento das falhas ósseas foi melhor nos membros tratados com a rhBMP-2 e preenchidos com enxerto esponjoso autólogo, em comparação aos membros não preenchidos. A resistência óssea foi maior para o grupo tratado com a proteína, assim como a avaliação histológica demonstrou que ocorreu maior formação de tecido ósseo e a presença de maior quantidade de osso maduro neste grupo. Os autores concluíram que a utilização da rhBMP-2 em defeitos ósseos induzidos pode acelerar a reparação óssea em equinos (PERRIER et al., 2008).

Em um estudo piloto recente, Cohen et al. (2012) pesquisaram os efeitos de um hidrogel sobre a reparação óssea de equinos. Quatro cavalos adultos hígidos foram submetidos à ostectomias de $7 \mathrm{~mm}$ em seus ossos $2^{\circ}$ e $4^{\circ}$ metacarpianos de ambos os membros torácicos. Em cada animal, dois dos defeitos foram preenchidos 
com o biomaterial e os outros dois foram mantidos como controle. Os animais foram avaliados clinicamente e por exame radiográfico 24 horas, 15, 30, 45 e 60 dias após o procedimento. As imagens radiográficas foram classificadas com escores subjetivos de preenchimento das falhas ósseas por três avaliadores cegos. Após 63 dias, os animais foram eutanasiados para a coleta de fragmentos ósseos para análise histomorfométrica de cortes calcificados.

Os animais não apresentaram claudicação após a indução das falhas e implantação do biomaterial. Foi observado edema discreto no local das lesões e todas as feridas cirúrgicas cicatrizaram sem complicações. Não houve diferença significativa quanto ao preenchimento das falhas entre os grupos quando consideradas as avaliações radiográfica e histológica. O material não causou inflamação local, tampouco inibição da deposição óssea. A conclusão dos autores foi que este pode ser considerado um material adequado uma vez que apresentou biocompatibilidade com o tecido ósseo equino. No entanto, sugerem estudos de sua associação com proteínas osteogênicas para aumentar a sua capacidade osteoindutora (COHEN et al, 2012).

\subsection{DENSITOMETRIA ÓPTICA RADIOGRÁFICA}

A utilização de técnicas densitométricas constitui uma importante ferramenta no estudo do esqueleto. A determinação da densidade mineral óssea é parte integral do diagnóstico, planejamento terapêutico e monitorização de indivíduos com alterações ósseas. Para avaliação da mineralização ou da densidade mineral óssea dos animais, torna-se necessário o emprego de técnicas de medidas in vivo; dentre elas se incluem a absorção direta por fótons, análise de ativação por nêutrons, tomografia computadorizada, fotometria radiográfica e a densitometria óptica em imagem radiográfica, sendo que esta última pode ser utilizada para uma análise sequencial da massa óssea, com um custo menor que as demais e tendo como fator preponderante a precisão (GUERRA; VULCANO; ROCHA 2006).

Apesar da grande variedade de técnicas de quantificação da densidade óssea na Medicina Veterinária, muitas delas requerem equipamentos de custo elevado, o que inviabiliza a sua aplicação como rotina. Embora válidas para avaliação da 
resistência óssea, as metodologias não invasivas de mensuração da resistência, estrutura e massa óssea só irão se tornar clinicamente viáveis, quando estudos forem realizados visando facilitar o manuseio do equipamento e a redução de seu custo (VULCANO; SANTOS; GODOY 2008).

Por se tratar de uma técnica recente, a densitometria óptica em imagem radiográfica é ainda pouco empregada na Medicina Veterinária. Esta metodologia já foi utilizada para avaliar a densidade mineral óssea do carpo ulnar de potros da raça Quarto de Milha, do carpo acessório de potros da raça Puro Sangue Inglês e de equinos atletas submetidos a provas de enduro (VULCANO; SANTOS; GODOY 2008). Ela também foi empregada por Frazão et al. (2012) para determinar a densidade óssea da região diafisária dorsal do terceiro metacarpiano de equinos e correlacionar esta à resistência mecânica óssea avaliada por ensaios biomecânicos.

A densitometria óptica radiográfica é uma técnica radiológica não invasiva, precisa, de fácil execução e de baixo custo, que avalia a variação da densidade mineral óssea por meio de imagens radiográficas. Ela é indicada para transpor as limitações visuais e a subjetividade da interpretação radiográfica simples (SILVA et al., 2007).

Este método não invasivo fornece informações equivalentes às conseguidas pela análise histológica, demonstrando ser altamente eficaz e promissor (GUERRA; VULCANO; ROCHA, 2006).

Por meio da avaliação da densidade do tecido ósseo é possível detectar precocemente lesões locais ou doenças sistêmicas, além de ser possível, quantitativamente, acompanhar o processo de evolução ou reparação do tecido ósseo (FONSECA, 2007).

A densidade radiográfica é aproximadamente proporcional à massa de osso localizado sob o feixe de raios $x$. O método envolve a obtenção de uma imagem radiográfica de uma região periférica de esqueleto (por exemplo, metacarpos, falanges, rádio, fêmur ou tíbia), simultaneamente com uma escala de referência feita a partir de uma liga de alumínio ou de hidroxiapatita, os quais possuem densidade semelhante à do tecido ósseo. Após o processamento da imagem, o osso e a escala de referência são então avaliados e a densidade óptica radiográfica é expressa em valores equivalentes aos degraus do material de que é constituída escala. Tal método é mais comumente aplicado para metacarpos e falanges (ADAMS, 2010). 
Apesar de a densitometria radiográfica ser um método de fácil realização e baixo custo, as variações radiográficas referentes à kilovoltagem, tempo de exposição, espessura dos tecidos moles, posicionamento e também fatores no processamento do filme podem causar alterações nos resultados finais, diminuindo, assim, a eficácia do método. Portanto, há necessidade de padronização da metodologia empregada para evitar qualquer influência nos valores obtidos (ALVES; STERMAN, 2010).

Para minimizar estes problemas técnicos faz-se necessária a presença de uma escala de referência. O alumínio tem sido usado para confecção da escala, por possuir uma curva de absorção de raios $x$ muito semelhante à dos ossos. A escala de alumínio, por possuir características conhecidas, serve como um padrão referencial densitométrico, permitindo estabelecer uma calibração pelo sistema computacional por comparação das tonalidades de cinza, minimizando possíveis alterações que a imagem possa apresentar em decorrência de variáveis radiológicas e gerando valores densitométricos expressos em equivalentes a milímetros de alumínio (mmAl) (ALVES; STERMAN, 2010).

\subsection{MICROSCOPIA ÓPTICA DE LUZ (MOL)}

Os métodos experimentais envolvendo animais para avaliação da densidade e arquitetura ósseas são geralmente os mesmos que os utilizados para os seres humanos. Densitometria, tomografia computadorizada periférica quantitativa ou absorciometria de dupla energia (DEXA), ressonância magnética e radiografia são métodos de análise de imagem que não requerem a morte ou injúria do animal, sendo, portanto, chamados de não invasivos. No entanto, a interpretação dos resultados obtidos a partir destes métodos está sujeita a erros e variabilidade, e o seu êxito depende não só na qualidade das imagens, mas também da interferência de fatores físicos, tais como a técnica de aquisição e a sobreposição de tecidos (HERNANDES et al., 2012).

Os métodos invasivos envolvem medidas histomorfométricas realizadas em cortes histológicos, obtidos por meio de biópsias ou ex-vivo, e têm a vantagem de permitir análise de densidade e arquitetura óssea. Eles fornecem dados quantitativos 
e qualitativos, pois incluem a contagem de células, avaliações imunohistoquímicas, dentre outras. Da mesma forma, os dados obtidos por histomorfometria estão sujeitos a erros de interpretação, resultante do processamento histológico de rotina (HERNANDES et al., 2012).

A MOL é importante ferramenta para avaliar objetivamente eventos histológicos. É, portanto, extremamente útil para estudar a dinâmica do tecido ósseo (HOLLINGER; BUCK; SCHMITZ, 1994).

A avaliação histológica da reparação de uma lesão óssea permite acompanhar e definir especificamente todas as etapas que ocorrem durante 0 processo, além de identificar fatores que possam interferir no mesmo (GUERRA; VULCANO; ROCHA, 2006).

A histomorfometria óssea é uma avaliação histológica que visa obter informações quantitativas e qualitativas sobre a estrutura e a remodelação óssea. É amplamente utilizada no desenvolvimento de pesquisas acerca de doenças ósseas metabólicas e da osteoporose. Tal metodologia é indispensável e de importância significativa na rotina clínica (LI; HUANG; XU, 2011).

Embora as amostras ósseas sejam geralmente descalcificadas nas técnicas histopatológicas rotineiras para facilitar o processamento do material, quando se analisa amostras calcificadas elas tendem a ser muito mais informativas (RAUCH, 2009).

O acompanhamento da regeneração e aposição óssea ao redor de implantes requer técnicas que permitam a avaliação dos tecidos duros sem a necessidade de descalcificação. A técnica de corte e desgaste tem como objetivo a obtenção de amostras de osso não descalcificadas para a avaliação histológica qualitativa e histomorfométrica. Tal metodologia foi desenvolvida para análise de procedimentos de regeneração de osso da crista alveolar (distração alveolar, elevação do seio, a aplicação de fatores de crescimento), na análise da aposição óssea sobre a superfície de diferentes biomateriais, incluindo os aloplásticos. Também tem sido utilizada no estudo de tecidos e restaurações dentárias ou próteses fixas, assim como para a observação dos tecidos moles adjacentes (SÁNCHEZ et al., 2005).

Por se tratar de uma técnica que requer considerável quantidade de tempo (algumas semanas, dependendo do tamanho da amostra), é mais comumente utilizada em estudos experimentais e ensino (SÁNCHEZ et al., 2005). 
Com o desenvolvimento dos meios de inclusão rígidos (resinas), de micrótomos e sistemas especiais de corte, tornou-se possível cortar osso calcificado. O sistema necessita de aparelhos específicos para a realização das diferentes fases do processo. O processamento do osso calcificado é feito seguindo cinco fases fundamentais: fixação, inclusão, corte, desgaste e coloração (SÁNCHEZ et al., 2005).

Para amostras pequenas (com menos do que $5 \mathrm{~mm}$ de espessura) a fixação de 24 a 48 horas é suficiente, enquanto para as amostras maiores ou com grande quantidade tecido ósseo compacto, são necessárias de 48 a 72 horas (SÁNCHEZ et al., 2005).

Os materiais mais utilizados como meio de inclusão são as resinas de epóxi para microscopia eletrônica (epóxi Spurr) e os derivados acrílicos, como por exemplo, resinas de glicolmetacrilato (GMA) ou de metilmetacrilato (MMA). Antes da inclusão é necessário desidratar a amostra para eliminar completamente a água e gordura. Isto é feito pela incorporação de concentrações crescentes de álcool ou acetona, de acordo com a resina que será utilizada, de modo a permitir a sua penetração adequada posteriormente (SÁNCHEZ et al., 2005).

Para o corte de amostras há diversos sistemas de microtomia disponíveis, embora nem todos eles sejam capazes de cortar implantes metálicos. Os corantes são os mesmos utilizados para a impregnação de amostras descalcificadas (SÁNCHEZ et al., 2005).

Como citado anteriormente, a histomorfometria permite uma avaliação quantitativa pela contagem das células, obtendo-se uma medição de duas dimensões (largura, comprimento e perímetro da área). A partir destes valores, vêm os parâmetros tridimensionais (espessura, a área de superfície e volume) das estruturas histológicas em diferentes tecidos. Atualmente, as avaliações histomorfométricas são realizadas por meio de softwares de computador específicos (SÁNCHEZ et al., 2005).

Os parâmetros histomorfométricos são resultado da interrelação de uma série de cálculos e medidas feitas no tecido ósseo, o que permite a definição quantitativa das características estruturais e funcionais do osso em condições normais, patológicas ou experimentais. Uma série de características histológicas do tecido ósseo pode ser avaliada a partir de amostras recolhidas utilizando esta técnica, como a diferenciação do osso imaturo recém-formado a partir do osso remodelado 
maduro. As amostras calcificadas também permitem a quantificação e diferenciação da matriz óssea desmineralizada, ou osteóide. É possível avaliar a integridade de biomateriais e quantificar o osso que cresce na interface. Permite também a análise da estrutura do revestimento do implante e a capacidade de reabsorção do material osteocondutor utilizado para regeneração óssea. Estas amostras também são utilizadas para a realização de estudos de histoquímica e imunohistoquímica e, portanto, para determinar diferentes proteínas que intervêm na biologia óssea (SÁNCHEZ et al., 2005).

\subsection{MICROSCOPIA ELETRÔNICA DE VARREDURA (MEV)}

O microscópio eletrônico de varredura (MEV) é um instrumento frequentemente utilizado na avaliação da superfície de implantes cirúrgicos e biomateriais. A análise microscópica da superfície de implantes é necessária para buscar melhores condições de acabamento superficial e osteointegração. Além disso, a análise microscópica da superfície óssea pode revelar indícios de alterações provocadas por um meio físico ou químico sobre a mesma (HAJE; THOMAZINI; VOLPON, 2007).

Atualmente, as biópsias ósseas são quase que exclusivamente estudadas por microscopia óptica de luz a partir de seções finas. O MEV permite a visualização da estrutura tridimensional do osso diretamente, produzindo informações que, de outro modo, exigiria a reconstrução meticulosa de cortes seriados (DEMPSTER; LINDSAY, 1985).

A fidelidade da topografia da superfície óssea e a facilidade de preparação de tecido para a análise por MEV tornam este um método conveniente para a análise microscópica das atividades regionais ou sistêmicas do esqueleto (MARKS JR.; CIELINSKI; SUNDQUIST, 1996).

Uma das características mais importantes do MEV é uma grande profundidade de campo em todas as ampliações, o que permite que as áreas acima e abaixo do plano focal apareçam sempre focadas. A profundidade de campo do MEV é 100 a 500 vezes maior do que a do microscópio óptico de luz (SAHAR; HONG; KOHN, 2005). Além do que, as câmaras de amostras de alguns MEV têm 
capacidade para estudar amostras relativamente grandes (como, por exemplo, dentes) exigindo, portanto, menor preparo das amostras e menor risco de induzir artefatos (SCHWEITZER et al., 2008).

A tecnologia do MEV baseia-se na emissão de um feixe de elétrons focado (diâmetro do feixe de aproximadamente $1 \mathrm{~nm}$ ) em toda a superfície da amostra para a formação de uma imagem topográfica (SCHWEITZER et al., 2008).

A análise por MEV requer a remoção de todo o material orgânico, pois este recobre as superfícies formadoras de osso e de repouso, tornando-as indistinguíveis. Amostras ósseas destinadas à MEV são geralmente fixadas em soluções de formalina neutra tamponada, glutaraldeído em tampão de cacodilato. Os protocolos de fixação não são tão rigorosos como aqueles para preservação de células, porque existe pouca deterioração das superfícies mineralizadas (MARKS JR.; CIELINSKI; SUNDQUIST, 1996).

Após a fixação, os espécimes são lavados com água destilada e tratados com solução de hipoclorito de sódio industrial ( $\mathrm{NaOCl}$ ) durante 2 a 12 horas, dependendo da densidade do revestimento orgânico. Em seguida as amostras são lavadas extensivamente em água destilada para remover os restos de células e matriz biológica, desidratadas numa série gradual de álcoois e secas ao ar. Posteriormente são posicionadas em suportes (stubs) e revestidas por materiais condutores (em geral, ouro), para, então serem observadas no MEV (MARKS JR.; CIELINSKI; SUNDQUIST, 1996).

A superfície da amostra é geralmente revestida com uma substância condutora tal como o carbono, liga de ouro/paládio, ou irídio depositados sob a forma de um fino filme (de apenas alguns nanómetros de espessura). As tecnologias mais recentes, como as de baixo vácuo ou de emissão de campo não exigem tal revestimento. O revestimento metálico pode produzir melhores imagens (SCHWEITZER et al., 2008).

A seguir serão descritos estudos que utilizaram o MEV para avaliar a estrutura óssea após a implantação de biomaterias. Tais trabalhos servirão como base para a discussão dos resultados obtidos neste experimento.

Fellah et al. (2006) implantaram biomaterial a base de polímero e fosfato de cálcio bifásico em defeitos críticos induzidos nas epífises distais do fêmur de coelhos e efetuaram avaliação dos sítios de implante por MEV após oito semanas de interação. Os autores concluíram que o biomaterial promoveu reparação óssea 
satifatória, apresentando ótima osteocondutividade e recomendaram o seu emprego na rotina de procedimentos ortopédicos para o preenchimento de defeitos críticos.

Em um estudo envolvendo a implantação biomaterial a base de hidroxiapatita na tíbia de coelhos, Chang et al. (2000) utilizaram a MEV para avaliar a responsividade do tecido ósseo à 3 diferentes configurações de porosidade do material. Os autores concluíram que o padrão estrutural do osso neoformado está intimamente relacionado à conformação do implante, mais especificamente no que diz respeito à sua porosidade.

Matsuda et al. (1995) compararam através da MEV a resposta do tecido ósseo da calvária de ratos a dois implantes distintos: um derivado de osso natural sinterizado e um composto sintético a base de hidroxiapatita. Foram estudadas amostras de diversos momentos pós-operatórios (1, 2, 3 e 5 semanas), as quais demonstraram que na presença do osso natural ocorre uma incorporação gradativa do material, o qual ao final do experimento funde-se completamente ao osso neoformado. Contudo, na presença do substituto sintético, apesar de ocorrer a formação de osso novo na superfície do implante, não observou-se a fusão entre os dois. Ocorreu menor invasão dos poros do material por tecido ósseo. Ou seja, este implante demonstrou menor osteocondutividade que o anterior.

Em estudo envolvendo humanos, Orsini et al. (2005) avaliaram a interface entre o tecido receptor e um enxerto a base de matriz óssea bovina mineralizada após 6 meses de interação. De acordo com os autores, as partículas do material implantado não interferiram no processo de reparação fisiológico, além de promover a formação de osso novo.

À semelhança deste estudo, as publicações citadas buscaram descrever a interação entre os implantes e o leito receptor ao nível estrutural, sempre considerando aspectos como a adesão e incorporação do material, indução da deposição óssea e sua magnitude, além da organização do tecido neoformado. 


\section{MATERIAL E MÉTODO}

A seguir serão descritos o delineamento experimental, materiais e métodos empregados durante o desenvolvimento do projeto de pesquisa.

\subsection{DELINEAMENTO EXPERIMENTAL}

Confeccionou-se uma falha na superfície diafisária dorsal de cada osso terceiro metacarpiano de seis equinos, por meio de ostectomia com serra trefina circular de $11 \mathrm{~mm}$ de diâmetro, transpondo toda a camada cortical-cis, a $10 \mathrm{~cm}$ de distância da epífise proximal e $1 \mathrm{~cm}$ medial ao ponto médio do MIII. A falha de um dos membros foi preenchida com biopolímero de poliuretana de mamona e a do membro contra lateral foi mantida sem preenchimento, como controle. A determinação de qual membro (direito ou esquerdo) seria mantido com e sem preenchimento foi feita aleatoriamente, através de sorteio.

Os animais foram monitorados por um período de 120 dias após o procedimento. Neste período efetuou-se avaliações radiográficas seriadas para o acompanhamento da densidade óssea durante o período de reparação óssea, além da comparação entre os membros preenchidos e não preenchidos com o polímero. Decorrido este prazo, os animais foram novamente submetidos a intervenção cirúrgica para obtenção de biópsia óssea e encaminhamento de material das regiões de interface dos sítios operatórios iniciais (osso/polímero ou falha) para análise histológica por microscopia eletrônica de varredura e óptica de luz.

A obtenção dos fragmentos de biópsia se deu pela utilização de uma serra trefina circular de $5 \mathrm{~mm}$ de diâmetro, também transpondo toda a camada cortical-cis da região de interface entre tecido ósseo/polímero, ou de tecido ósseo/falha sem preenchimento. Foram coletados dois fragmentos de biópsia de cada membro, alinhados e localizados no eixo longitudinal das falhas em relação aos membros.

A figura 1 contém um esquema de todos os procedimentos e avaliações realizados durante o projeto. 
Figura 1 - Esquema de procedimentos e avaliações realizados no estudo

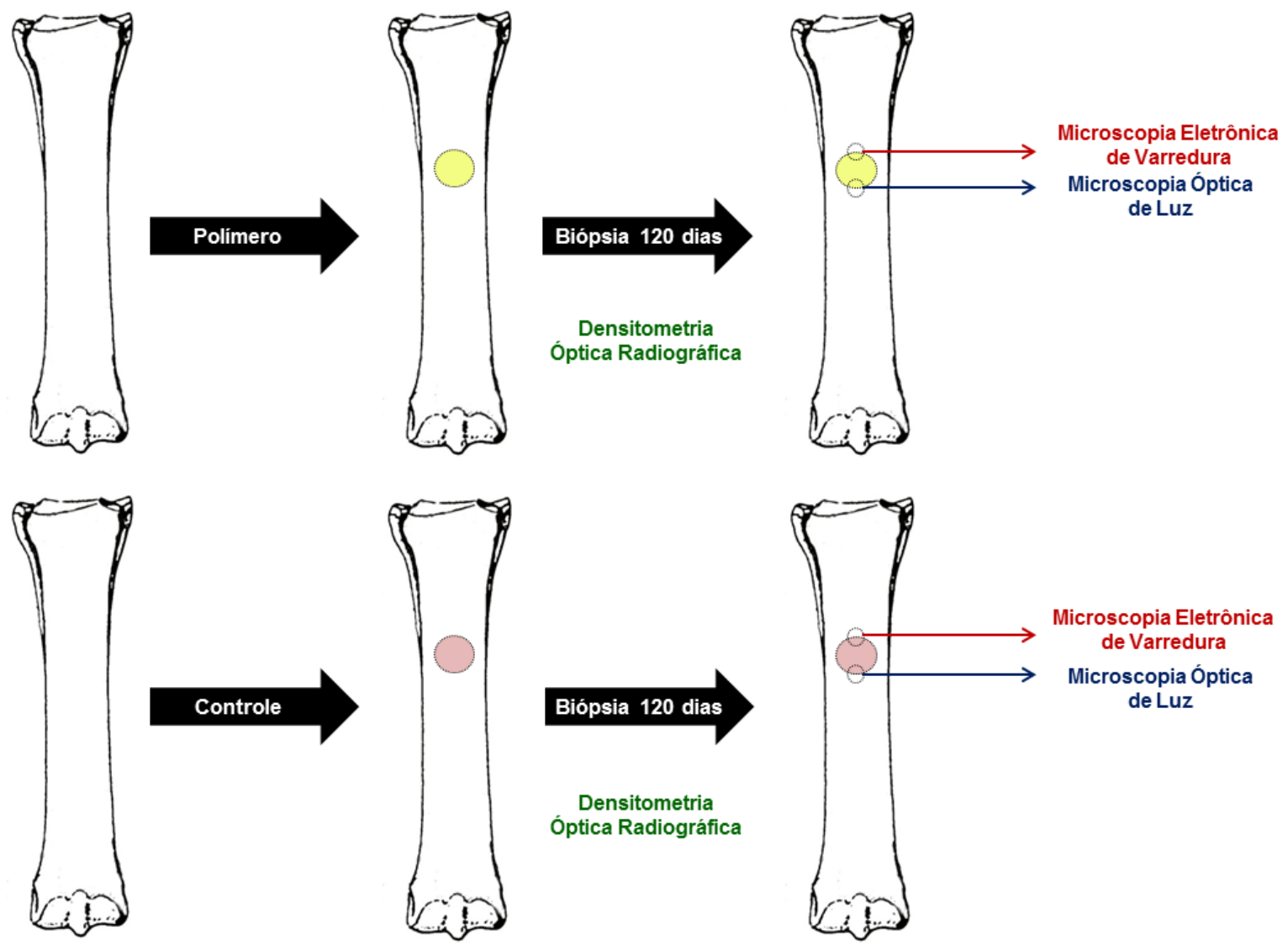

Fonte: Selim, M. B. (2013)

\subsection{MATERIAL}

A usinagem do polímero, confecção das falhas ósseas e coleta de material de biópsia foi possível através da utilização de serras trefinas circulares de $13 \mathrm{~mm}, 9 \mathrm{~mm}$ e $5 \mathrm{~mm}$, respectivamente, adquiridas da empresa ORTOP ${ }^{\circledR}$. As serras trefinas foram acopladas a perfuradora ortopédica modelo Trauma Recon System - TRS da marca Synthes $^{\circledR}$ (figura 2). 
Figura 2 - Material utilizado para a confecção das falhas e biópsias ósseas

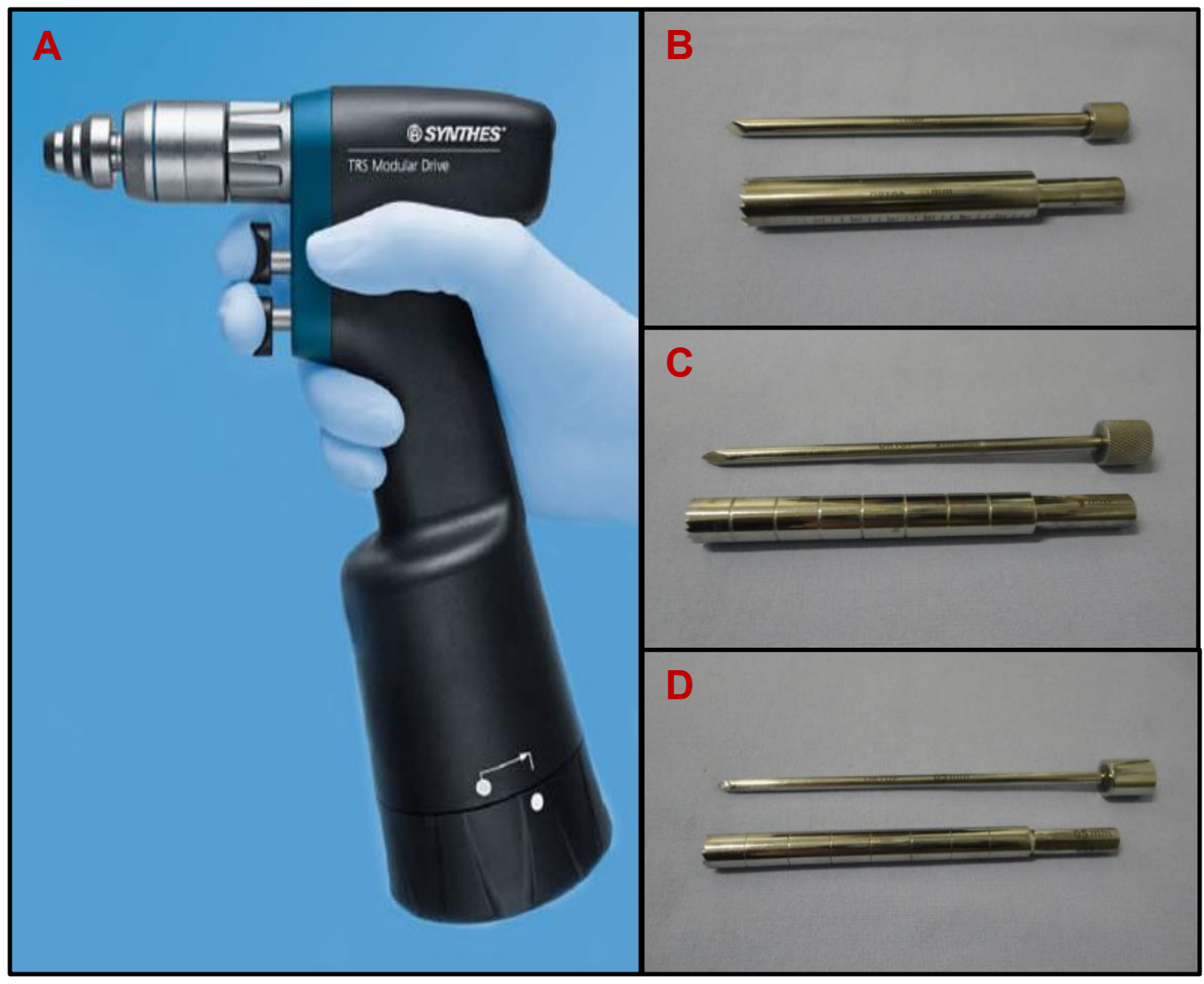

A: Perfuradora utilizada para acoplar as serras trefinas para a usinagem do polímero e realização das falhas e biópsias ósseas; B: Serra trefina de 13mm; C: Serra trefina de 9mm; D: Serra trefina de $5 \mathrm{~mm}$.

Fonte: A: SYNTHES ${ }^{\circledR}$ (2011); B, C e D: Selim, M. B. (2013)

O biopolímero de poliuretana de mamona (figura 3A) utilizado para preencher as falhas ósseas foi gentilmente cedido pela empresa Poliquil. Trata-se do “Composto Ósseo de Rícinus" (COR), desenvolvido em 1998 pelo Prof. Dr. Gilberto Orivaldo Chieriche e equipe, no Instituto de Química de São Carlos da Universidade de São Paulo. A apresentação do biomaterial cedido foi sob a forma de blocos porosos de coloração amarelada, estéreis, embalados individualmente (figura 3B).

De acordo com a empresa, o COR é uma poliuretana composta por um prépolímero derivado de isocianato, um poliol poliéster derivado do óleo de mamona e carbonato de cálcio. A relação de mistura é de 1,00 do pré-polímero para 0,65 de poliol e o carbonato de cálcio corresponde a $50 \%$ da soma da massa dos dois componentes. 
Figura 3 - Polímero a base de poliuretana de mamona

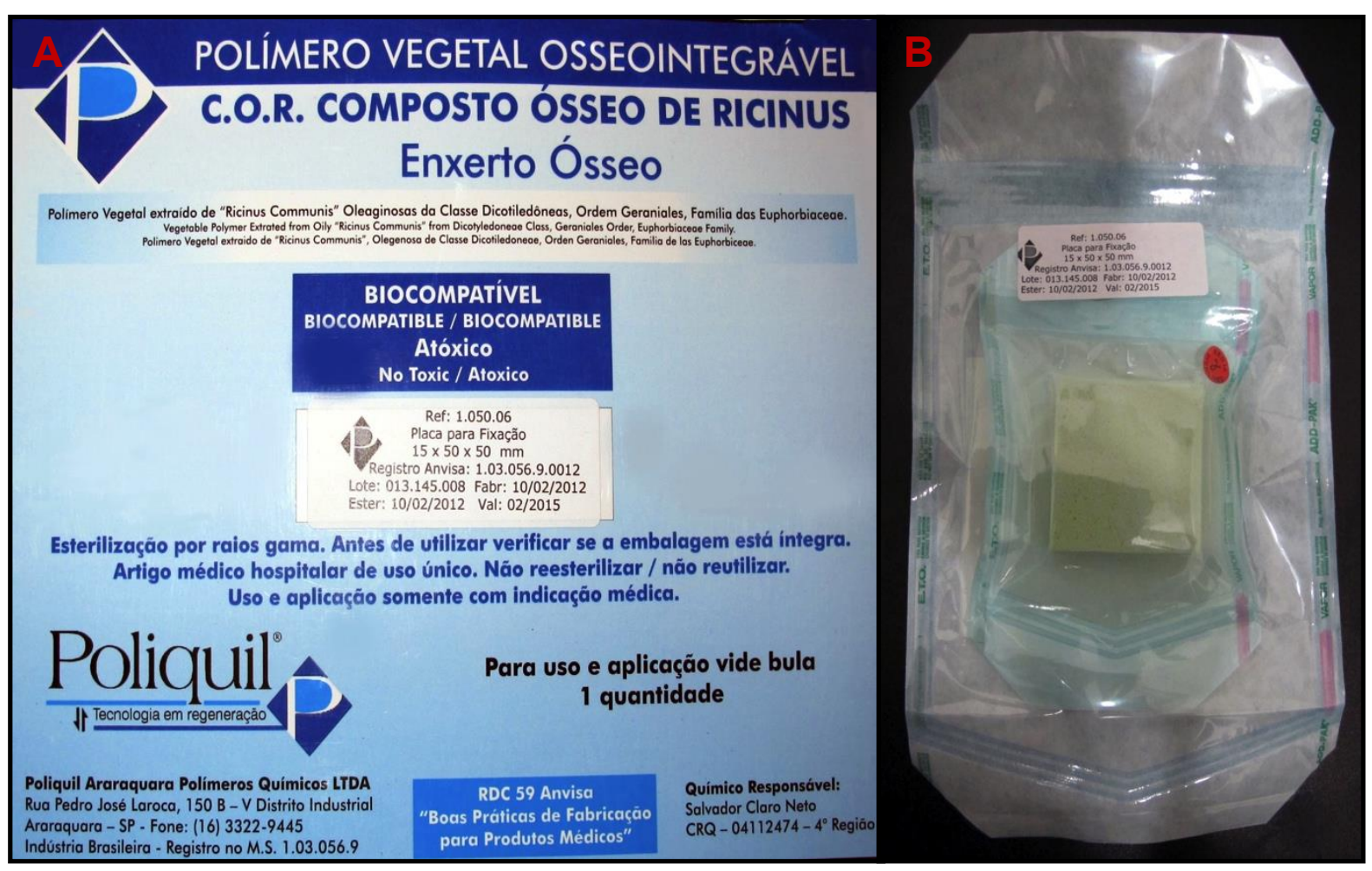

A - Aspecto da embalagem externa do COR, com os dados da empresa e especificações do produto; B - Aspecto do produto e de sua embalagem estéril.

Fonte: Selim, M. B. (2013)

\subsection{ANIMAIS}

Foram avaliados seis equinos hígidos, do sexo masculino, adultos e orquiectomizados. No transcorrer do estudo os animais foram mantidos em regime de estabulação, receberam água e feno à vontade e alimento concentrado comercial calculado com base no peso vivo, levando em consideração uma dieta de manuntenção.

\subsection{PROCEDIMENTO ANESTÉSICO}

Para a realização dos procedimentos cirúrgicos os animais foram submetidos 
anestesia com cloridrato de detomidina intravenoso $\left(0,01 \mathrm{mg} \cdot \mathrm{kg}^{-1}\right)$; indução anestésica com diazepam $\left(0,05 \mathrm{mg} \cdot \mathrm{kg}^{-1}\right)$ associado a cloridrato de quetamina intravenosos ( $2 \mathrm{mg} \cdot \mathrm{kg}^{-1}$ ), seguida da administração intravenosa de $500 \mathrm{ml}$ de éter gliceril guaiacol (100mg. $\mathrm{kg}^{-1}$ ) diluído em solução fisiológica a 0,9\% para ação miorrelaxante; manutenção da anestesia com isoflurano vaporizado em oxigênio a $100 \%$. No período trans-operatório foi administrado o analgésico opióide cloridrato de tramadol (2 mg. $\mathrm{kg}^{-1}$ ) diluído em 1,0l de solução de Ringer com Lactato pela via intravenosa. Durante a recuperação anestésica os animais foram sedados com cloridrato de xilazina intravenoso $\left(0,3 \mathrm{mg} \cdot \mathrm{kg}^{-1}\right)$. Em associação ao protocolo anestésico foi realizado bloqueio regional de quatro pontos altos em ambos os membros com $5,0 \mathrm{ml}$ de cloridrato de lidocaína a $2 \%$ associado a $5,0 \mathrm{ml}$ de cloridrato de bupivacaína a 0,5\%, além de perfusão regional com $20 \mathrm{ml}$ de lidocaína a $2 \%$ e $1,0 \mathrm{~g}$ de sulfato de amicacina diluídos em $40 \mathrm{ml}$ de solução fisiológica.

Para maior eficácia e segurança durante o procedimento anestésico, os animais tiveram os seguintes parâmetros monitorados durante todo o procedimento: pressão arterial invasiva, frequências cardíaca e respiratória, capnografia (pressão parcial de $\mathrm{CO}_{2}$ ), oximetria de pulso (saturação da hemoglobina) e concentração do agente anestésico.

\subsection{PROCEDIMENTOS CIRÚRGICOS}

\subsubsection{Falha óssea e preenchimento com polímero}

Com o animal anestesiado e posicionado em decúbito lateral procedeu-se à antissepssia de toda a extensão da região dos terceiros metacarpianos (previamente tricotomizados) com soluções de digluconato de clorexidina degermante a $2 \%$ e digluconato de clorexidina alcoólica a $0,5 \%$.

Após o posicionamento dos campos cirúrgicos iniciou-se o procedimento com incisão de pele semi circular de aproximadamente $5 \mathrm{~cm}$, com a concavidade voltada para a face medial do membro, localizada há aproximadamente $10 \mathrm{~cm}$ abaixo da articulação carpo-metacarpiana. Foi realizado afastamento lateral do tendão 
extensor digital comum e divulsão do tecido subcutâneo até a identificação do periósteo. Seguiu-se a incisão longitudinal do periósteo e rebatimento do mesmo com exposição da diáfise do MIII (figura 4).

Figura 4 - Sequência de procedimentos para a confecção das falhas ósseas

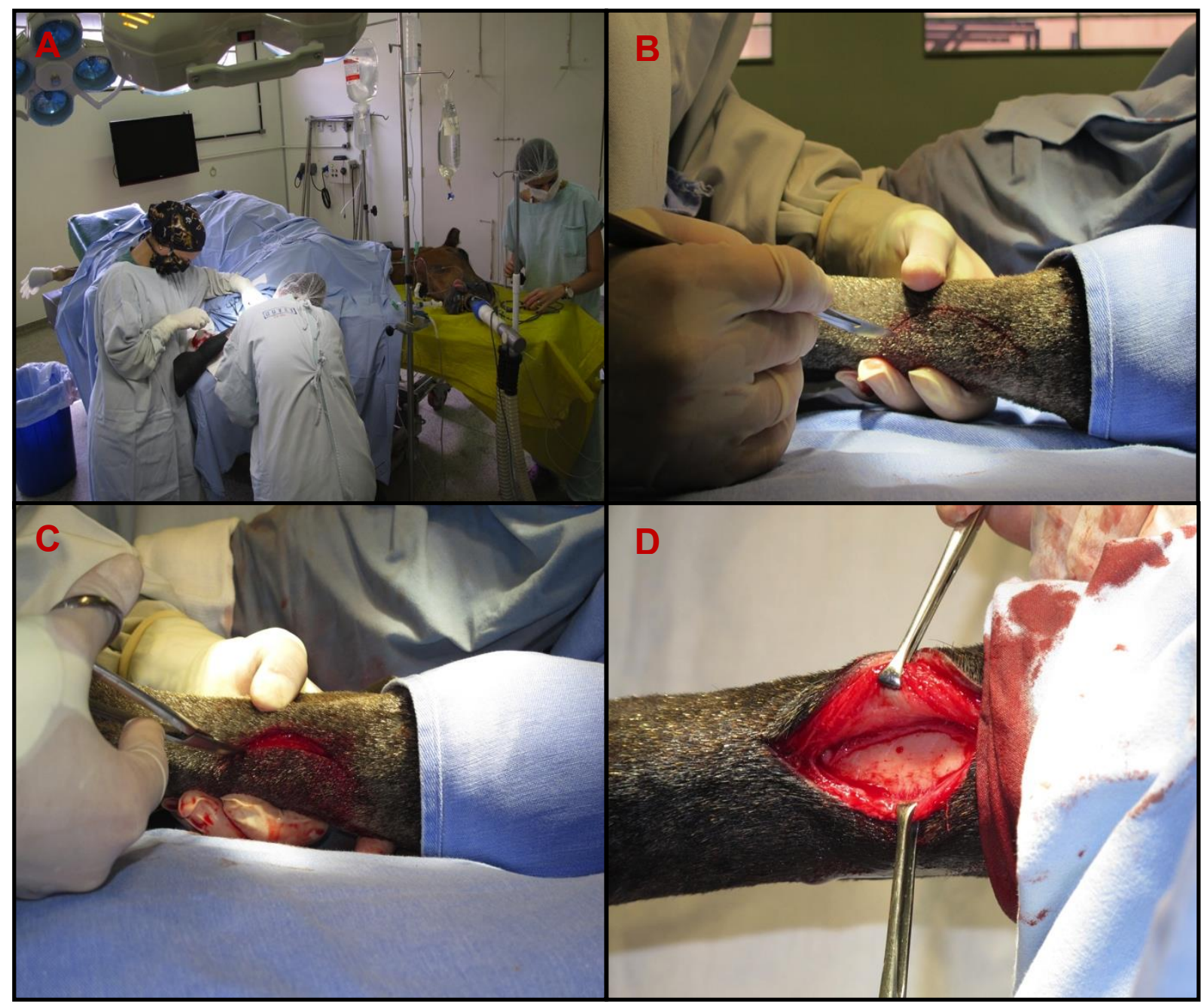

A - Animal sob anestesia geral e em decúbito lateral; B - Incisão de pele em formato semi circular; C - Divulsão do tecido subcutâneo; D - Exposição da diáfise do MIII.

Fonte: Selim, M. B. (2013)

Com a exposição da superfície óssea, realizou-se a perfuração da camada óssea cortical, sob irrigação com solução de $1,0 \mathrm{~g}$ de sulfato de amicacina diluído em 1,0l de solução de Ringer com Lactato, com auxílio de broca trefina de $9 \mathrm{~mm}$ de diâmetro, acoplada à perfuradora posicionada perpendicularmente ao eixo longitudinal do MIII. Em ato contínuo retirou-se fragmento de $11 \mathrm{~mm}$ de diâmetro e 
espessura variável, determinada individualmente, sendo o limite a transposição completa da camada cortical-cis de cada animal (figura 5).

Figura 5 - Sequência de procedimentos para a confecção das falhas ósseas

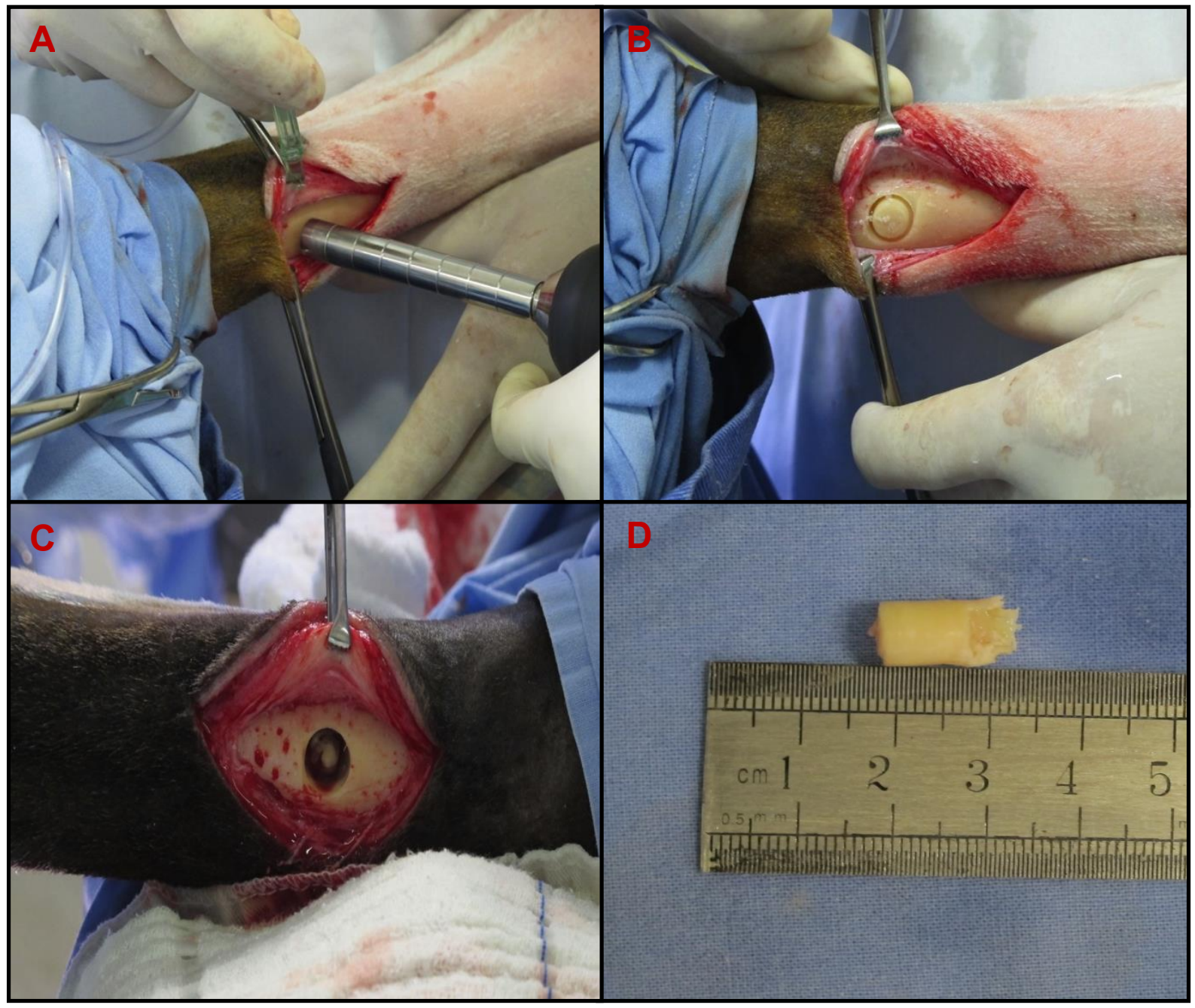

A - Perfuração da cortical óssea com serra trefina; B - Aspecto da superfície óssea durante a perfuração; C - Aspecto da superfície óssea após a completa transposição da camada cortical-cis, com exposição da cavidade medular; D - Fragmento obtido após a perfuração do MIII.

Fonte: Selim, M. B. (2013)

Após a retirada do fragmento efetuou-se o preenchimento da falha com 0 polímero de poliuretana de mamona previamente usinado com auxílio de broca trefina de $13 \mathrm{~mm}$. O ajuste do diâmetro do polímero foi realizado com lâmina de bisturi até a sua perfeita acomodação no interior da falha óssea (figura 6). Em seguida, seccionou-se o excesso de polímero rente à superfície do osso MIII com lâmina de bisturi (figura 7). 
Findado o procedimento no tecido ósseo, reposicionou-se o tendão extensor digital comum e aproximou-se o periósteo e tecido subcutâneo em bloco com fio de poliglactina 910 número 2.0 em padrão de sutura contínuo simples. A sutura de pele foi realizada com fio de mononylon número 2.0 em padrão contínuo simples, seguida de limpeza da ferida cirúrgica e confecção de bandagem compressiva.

Figura 6 - Sequência de procedimentos para o preenchimento das falhas ósseas com o biomaterial

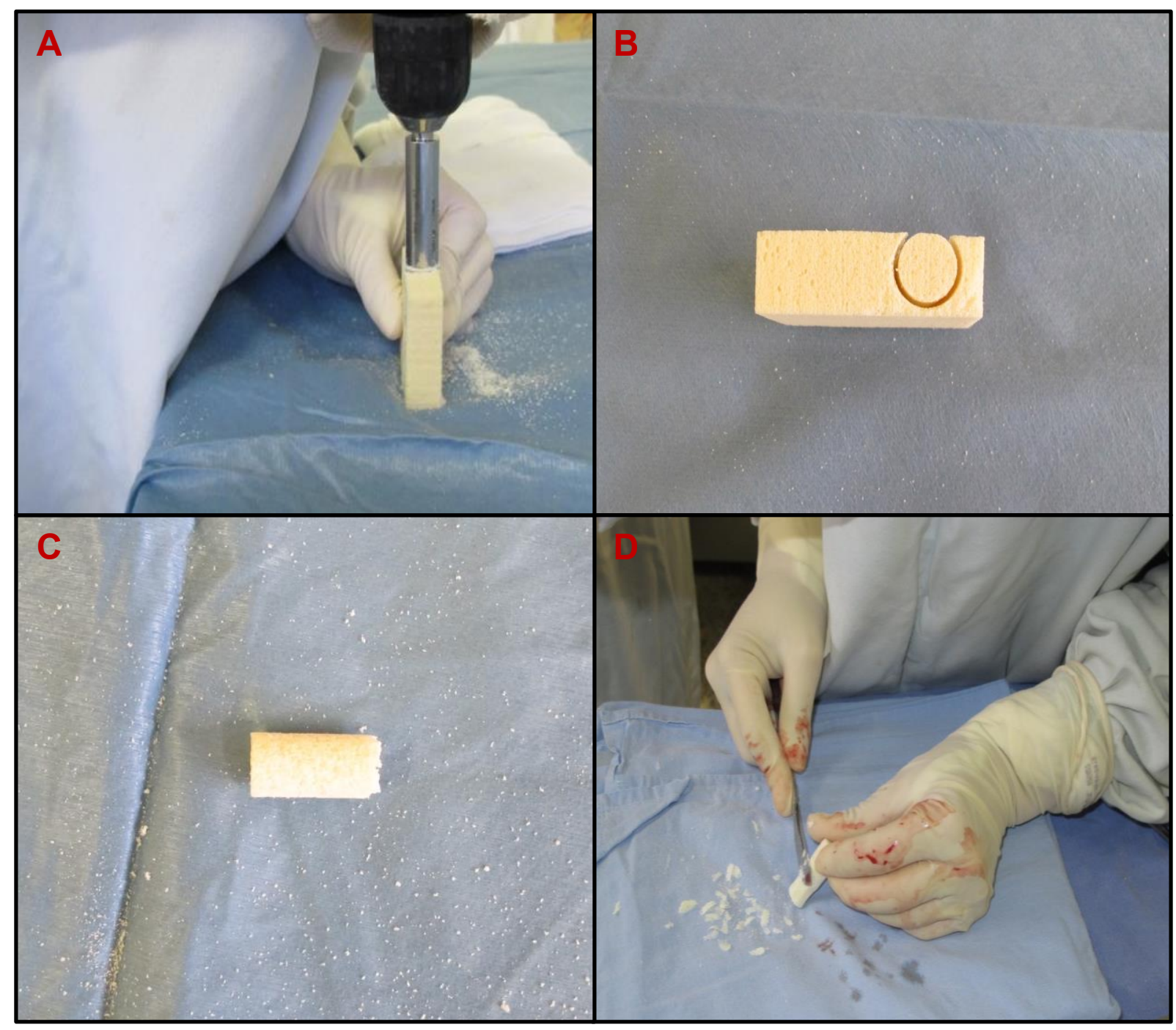

A - Usinagem do bloco de polímero com serra trefina de 13mm; B - Bloco após a usinagem, com cilindro de polímero ainda aderido; C - Aspecto do cilindro de polímero após o destacamento do bloco; D - Ajuste do diâmetro do cilindro para inserção no interior da falha óssea.

Fonte: Selim, M. B. (2013) 
Figura 7 - Sequência de procedimentos para o preenchimento das falhas ósseas com o biomaterial

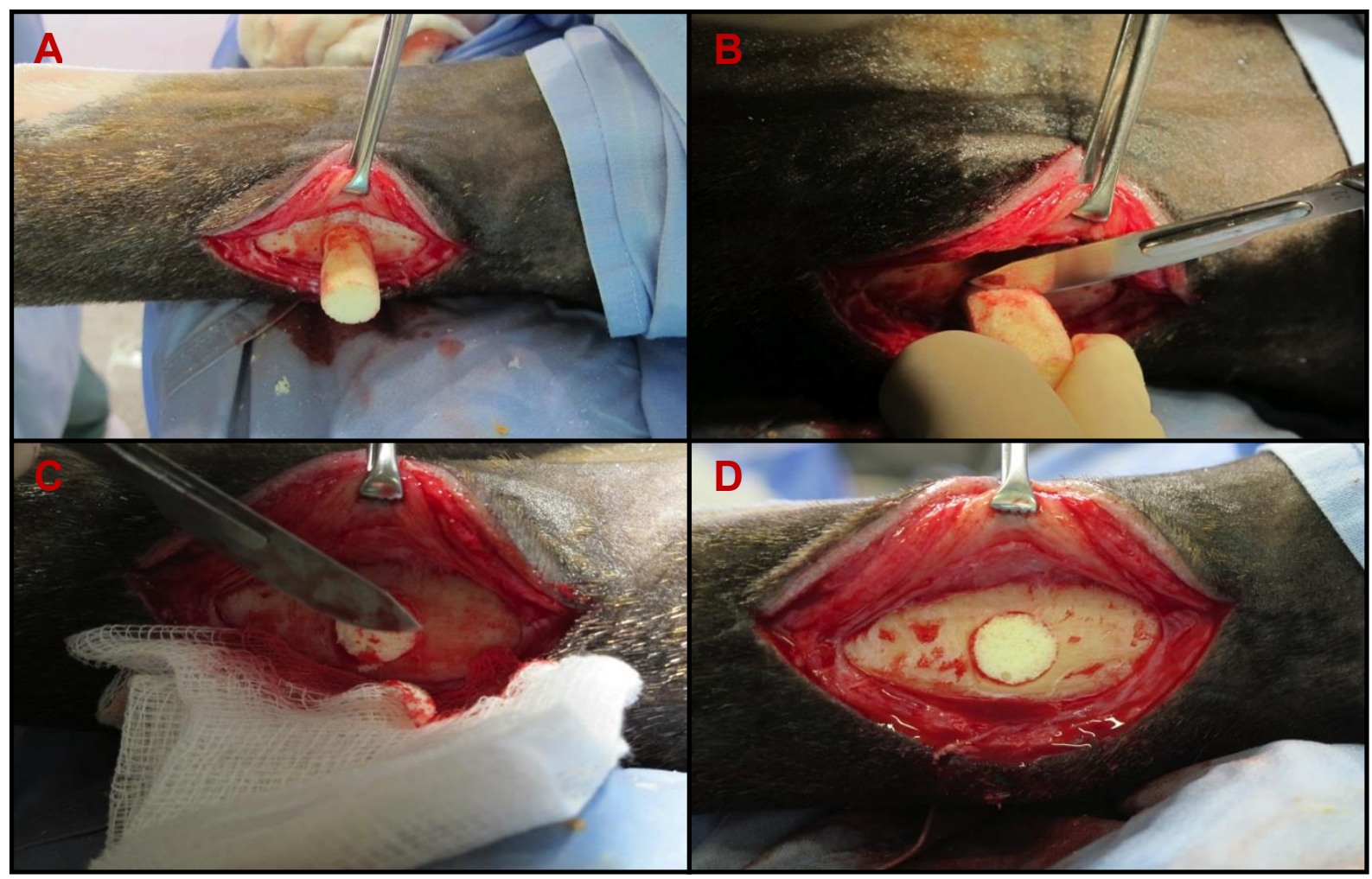

A - Inserção do cilindro de polímero no interior da falha óssea; B - Corte do excesso de material; C Nivelamento do polímero com a superfície óssea; D - Aspecto final após a implantação do biomaterial.

Fonte: Selim, M. B. (2013)

Após o procedimento em um dos membros torácicos, foi seguido o mesmo protocolo no membro contralateral, sendo este mantido sem preenchimento.

Os fragmentos ósseos removidos durante a confecção das falhas foram seccionados ao meio e encaminhados para análise histológica por microscopia óptica de luz e por microscopia eletrônica de varredura, com intuito de registrar o padrão morfológico para o tecido ósseo equino e servir de modelo comparativo com as biópsias coletadas posteriormente. 


\subsubsection{Biópsia óssea}

Durante as biópsias ósseas foi seguida a mesma sequência de procedimentos efetuados durante a confecção das falhas ósseas, até o momento de incisão e divulsão do periósteo para a exposição da superfície diafisária do MIII e localização dos sítios inicialmente operados.

As falhas dos membros mantidos como controle apresentavam redução visível de seu diâmetro inicial, assim como grande aderência e espessamento do periósteo que as recobria. Além disso, havia a invaginação de uma porção de periósteo para o interior das falhas. Este material precisou ser divulsionado e ter o seu excesso excisado para exposição da região de interface das lesões (figura 8).

Após a localização da lesão inicial, procedeu-se à perfuração da camada óssea da região de interface entre tecido ósseo/polímero ou de tecido ósseo/falha sem preenchimento, sob irrigação de solução de $1,0 \mathrm{~g}$ de sulfato de amicacina diluído em 1,0l de solução de Ringer com Lactato, com auxílio de broca trefina de $5 \mathrm{~mm}$ de diâmetro acoplada à perfuradora posicionada perpendicularmente ao eixo longitudinal do MIII. Foram, então, retirados dois fragmentos de $5 \mathrm{~mm}$ de diâmetro cada e espessura variável, determinada individualmente, sendo o limite a transposição completa da camada cortical-cis de cada animal.

Foi necessária a coleta de dois fragmentos ósseos de cada membro, para que se obtivesse quantidade adequada de material para as análises por microscopia óptica de luz e microscopia eletrônica de varredura. A região de eleição para a obtenção dos fragmentos seguiu o eixo longitudinal das falhas em relação aos membros, sendo retirados dois fragmentos alinhados, um proximal e outro distal em relação à articulação carpo-metacarpiana (figura 8).

Após a coleta, cada fragmento foi seccionado ao meio, de modo que cada novo fragmento contivesse material da região de interface. A divisão foi necessária para que se obtivesse a quantidade adequada de material para ser destinada a todas as análises histológicas contempladas no projeto.

Após a retirada dos fragmentos, reposicionou-se o tendão extensor digital comum e procedeu-se à aproximação do periósteo e tecido subcutâneo em bloco com fio de poliglactina 910 número 2.0, em padrão de sutura contínuo simples. A sutura de pele foi realizada com fio mononylon número 2.0, no padrão contínuo 
simples, seguida de limpeza da ferida cirúrgica e confecção de bandagem compressiva. Após o procedimento em um membro torácico, foi seguido o mesmo protocolo no membro contralateral.

Figura 8 - Sequência de procedimentos de biópsia óssea de falha não preenchida com biomaterial

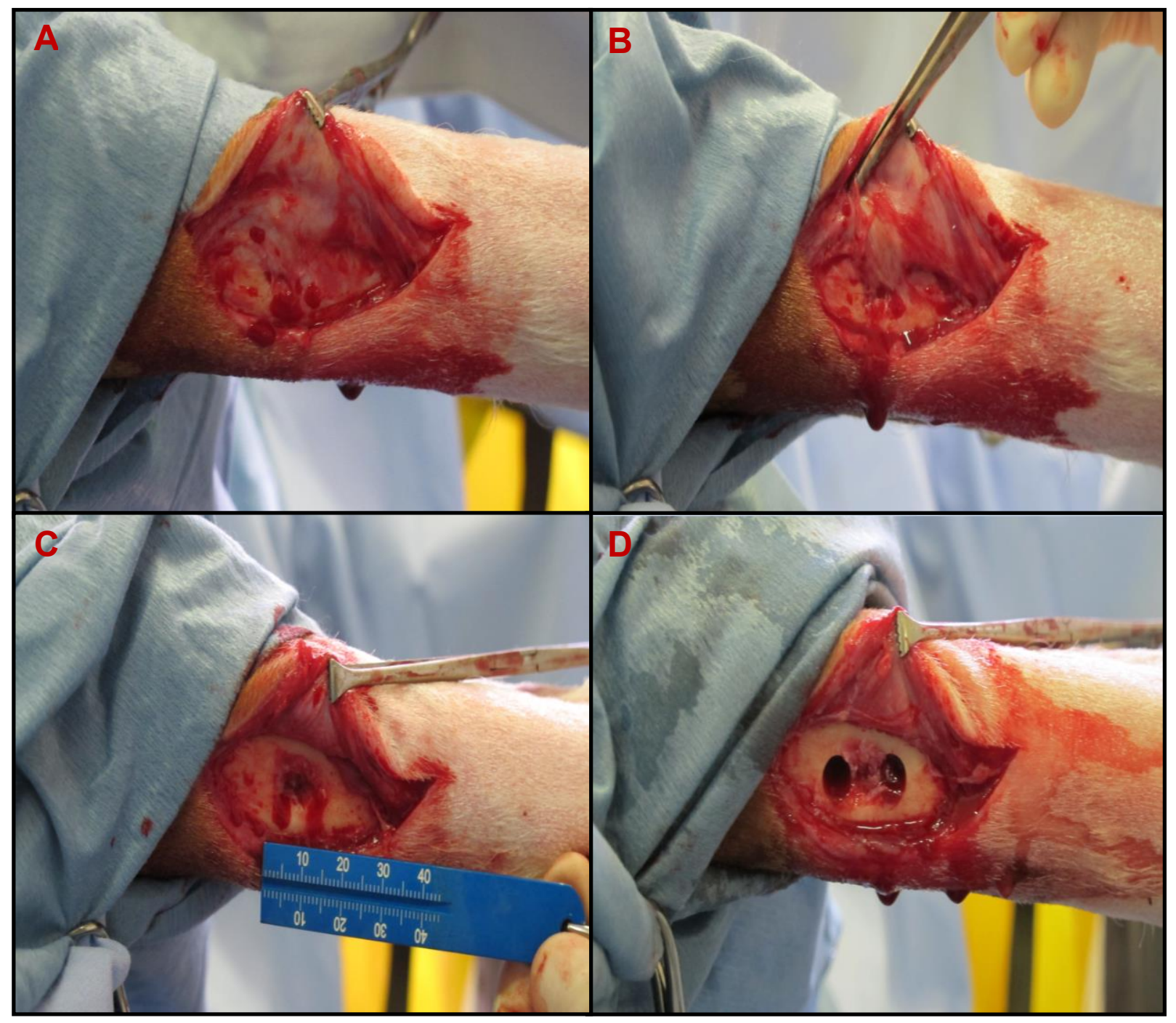

A - Espessamento e aderência do periósteo sobre a falha; B - Invaginação do periósteo para o interior da falha; C - Visualização da falha após excisão do excesso de periósteo; D - Aspecto após a coleta dos fragmentos de biópsia.

Fonte: Selim, M. B. (2013)

Nos membros que receberam o polímero, também foi observado espessamento do periósteo que recobria as falhas, no entanto, o mesmo não se 
apresentava aderido e/ou invaginado no interior das mesmas ou à superfície do polímero. O diâmetro inicial dos defeitos sofreu pequena alteração (figura 9A).

Figura 9 - Biópsia óssea de falha preenchida com biomaterial

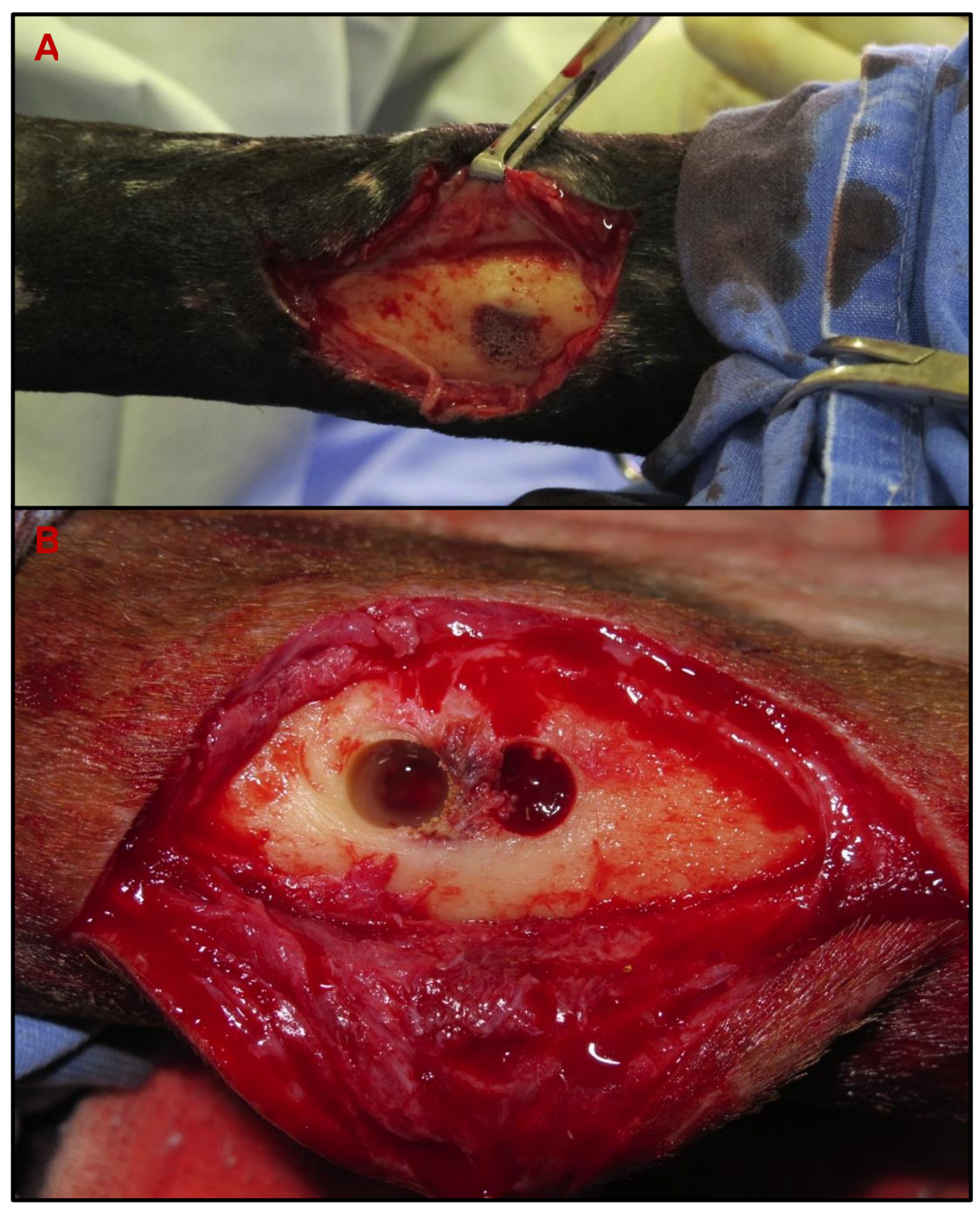

A - Aparência da falha e do periósteo após 120 de implantação; B - Aspecto após a coleta dos fragmentos de biópsia.

Fonte: Selim, M. B. (2013) 


\subsection{PROCEDIMENTOS PÓS-OPERATÓRIOS}

Os procedimentos pós-operatórios consitiram em exame físico, de claudicação, medicação e curativo dos animais. A avaliação física baseava-se no exame físico e inspeção visual da ferida cirúrgica, quanto à presença de deiscência, secreções e reação inflamatória.

O exame físico foi realizado diariamente, sendo aferidas as frequências cardíaca e respiratória, tempo de preenchimento capilar, coloração de mucosas, termperatura retal e motilidade intestinal. $O$ exame físico foi realizado diariamente durante todo o período de avaliação dos animais (120 dias) e por 30 dias após as biópsias ósseas.

A ferida cirúrgica foi inspecionada no momento da troca dos curativos, realizada a cada 3 dias. Após a remoção da bandagem, a ferida cirúrgica era higienizada com gaze estéril embebida em solução fisiológica e recoberta com pomada cicatrizante (Ganadol $^{\circledR}$, Fort Dodge Saúde Animal Ltda). Posteriormente, confeccionava-se nova bandagem compressiva. Tal procedimento foi realizado até a retirada dos pontos, aos quinze dias de pós-operatório.

Quanto à avaliação de claudicação, foi utilizada a graduação padronizada pela AAEP (American Association of Equine Practitioners), a qual varia de 0 a 5, em que:

Grau 0: claudicação imperceptível sob qualquer circunstância;

Grau 1: claudicação de difícil observação, não evidente de forma consistente independentemente das cirucunstâncias (por exemplo, sustentação de peso, à movimentação em círculo, inclinação, superfícies rígidas, etc);

Grau 2: claudicação de difícil observação ao passo ou ao trote em linha reta, mas evidente de forma consistente em algumas situações como as citadas no item anterior;

Grau 3: claudicação consistentemente observada ao trote em todas as situações;

Grau 4: claudicação óbvia ao passo;

Grau 5: claudicação óbvia, mínima sustentação de peso à movimentação ou em repouso; inabilidade de locomoção. 
A avaliação de claudicação consistiu na observação dos animais durante a locomoção ao passo e ao trote. Ela foi realizada previamente e aos 7, 15, 30, 60, 90 e 120 dias após o procedimento cirúrgico. As avaliações foram registradas em vídeo para posterior análise, caso houvesse necessidade.

A medicação administrada consistiu em sulfato de amicacina intravenoso na dose de $15 \mathrm{mg} \cdot \mathrm{kg}^{-1}$, diluído em $500 \mathrm{ml}$ de solução fisiológica a 0,9\%, a cada 24 horas, durante cinco dias; e fenilbutazona na dose de $4,4 \mathrm{mg} \cdot \mathrm{kg}^{-1}$, a cada 24 horas, durante 5 dias.

Além disso, os animais faziam caminhadas de 15 a 20 minutos por dia, pelo menos três vezes por semana, a partir da segunda semana de pós operatório, .

Os procedimentos citados, com exceção da avaliação de claudicação, foram repetidos também após as biópsias ósseas.

\subsection{MÉTODOS DE AVALIAÇÃO}

O comportamento da estrutura óssea frente à implantação do biopolímero foi avaliado através da densitometria óssea radiográfica, análise histopatológica por microscopia óptica de luz e por microscópia eletrônica de varredura. Cada um dos métodos de avaliação será descrito a seguir.

\subsubsection{Densitometria óptica radiográfica}

Os animais tiveram os seus MIII radiografados em diversos momentos para a determinação da densidade óptica e também para o acompanhamento do processo de reparo ósseo na presença do biopolímero. O primeiro exame foi executado no pré-operatório, como controle. As avaliações subsequentes ocorreram nos $7^{\circ}$, 15ํㅜㄴ, $30^{\circ}, 60^{\circ}, 90^{\circ}, 120^{\circ}$ dias pós-operatórios.

As radiografias foram realizadas junto ao Serviço de Diagnóstico por Imagem do Departamento de Cirurgia da Faculdade de Medicina Veterinária e Zootecnia da Universidade de São Paulo. 
Foram registradas duas projeções radiográficas dos MIII de ambos os membros torácicos, a dorsopalmar e a lateromedial. Durante os exames radiográficos os animais foram mantidos em estação, contidos com auxílio de cabresto de corda.

Para a projeção dorsopalmar, posicionou-se o cassete digital rente à face palmar do MIII. Com o aparelho de emissão de raios $x$ a uma distância de aproximadamente $60 \mathrm{~cm}$ da face dorsal do membro torácico e o feixe de raios colimado sobre a região de interesse, foram emitidas as ondas de raio x (figura 10A). A técnica padronizada foi de $75 \mathrm{kV}$ de tensão e e 2,5mAs de tempo de exposição.

No momento da aquisição das imagens na projeção dorsopalmar, foi afixada uma escala de alumínio (penetrômetro) ao cassete para a calibração do sistema de tonalidades e posterior determinação da densidade óssea. A escala de alumínio utilizada tem 25 degraus com diferença de $1 \mathrm{~mm}$ de altura entre cada um deles, assim sendo, o degrau 1 o possui $1 \mathrm{~mm}$ de altura e o $25^{\circ}, 25 \mathrm{~mm}$ (figura 11).

Durante a projeção lateromedial, o cassete foi posicionado rente à face medial do MIII, e o aparelho de raio $x$ apontado para a face lateral do membro torácico, sendo a distância do emissor de raios $x$ até 0 membro e a técnica radiográfica as mesmas descritas anteriormente (figura 10B).

Figura 10 - Exame radiográfico

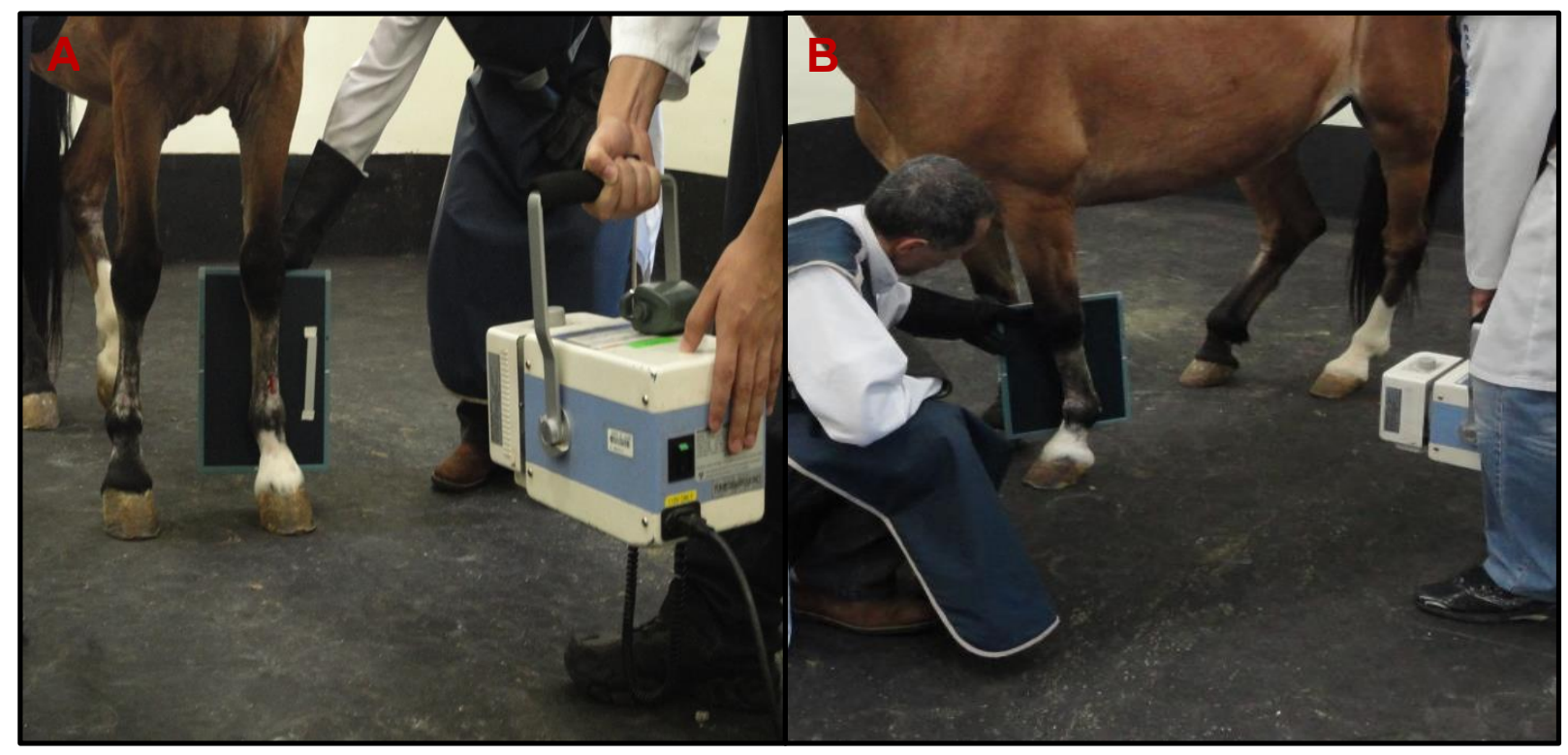

A - Projeção dorsopalmar, com escala de alumínio afixada no cassete; B - Projeção lateromedial. Fonte: Selim, M. B. (2013) 
Figura 11 - Escala de alumínio utilizada para a determinação da densidade óptica radiográfica

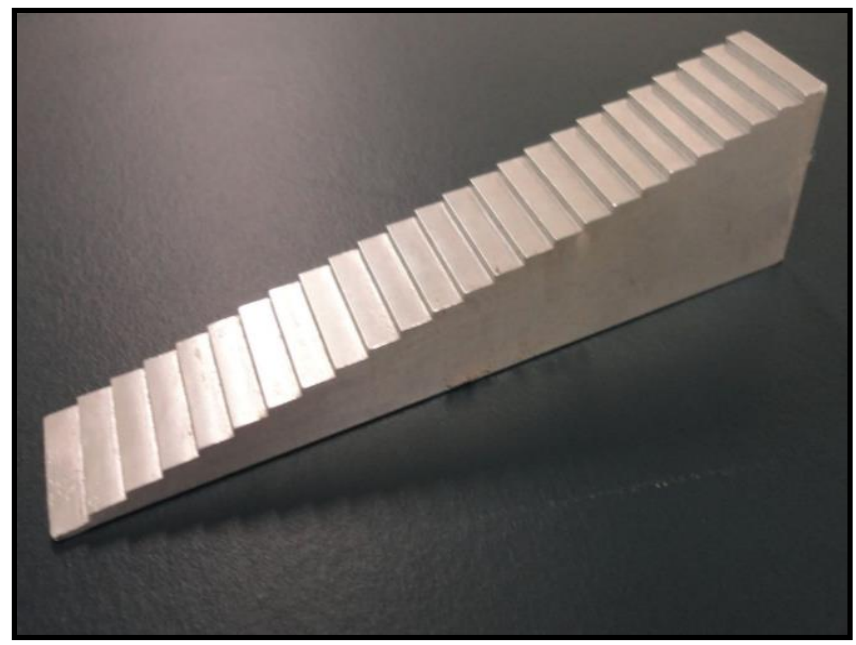

Fonte: Selim, M. B. (2013)

As imagens rediogáfricas foram obtidas a partir da utilização do emissor de raios x portátil modelo PXP-20HF, da marca POSKON ${ }^{\circledR}$; e de cassetes digitais modelo FCR IP Cassete Type CC, tamanho $24 \times 30 \mathrm{~cm}$, da marca Fujifilm ${ }^{\circledR}$ (figuras 12 e 13)

Figura 12 - Aparelho de emissão de raios x utilizado durante as avaliações radiográficas

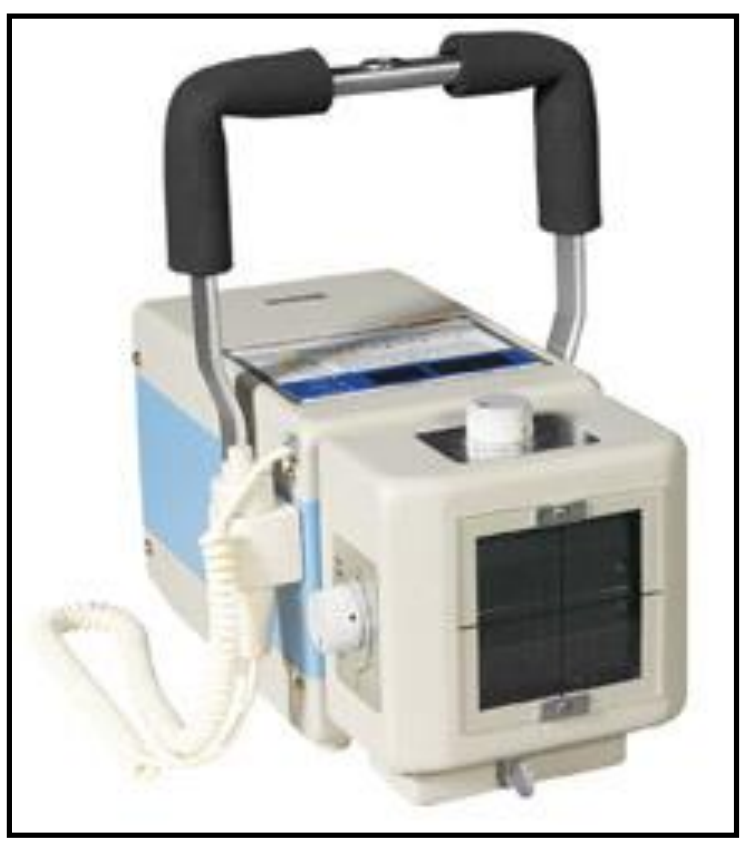

Fonte: $\mathrm{POSKON}^{(\Theta)}(2013)$ 
Figura 13 - Cassete digital empregado para a aquisição das imagens radiográficas (frente e verso)

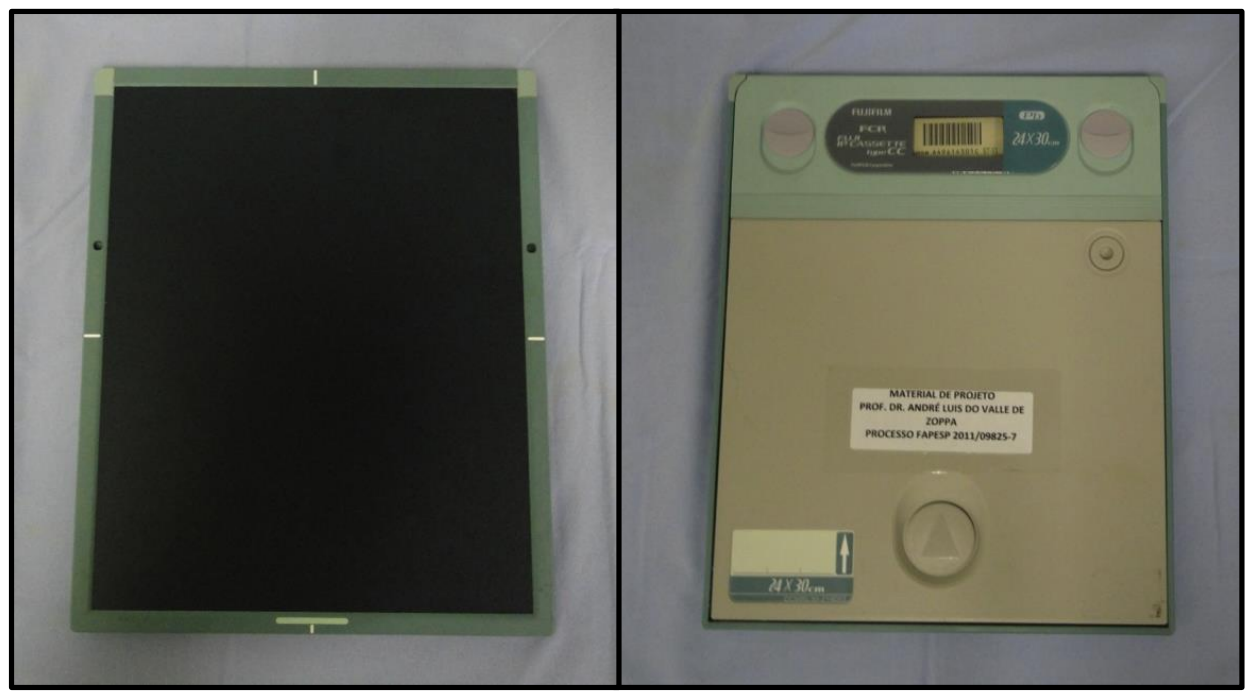

Fonte: Selim, M. B. (2013)

Posteriormente, as imagens foram analisadas em computador com auxílio do programa ImageJ $1.46 \mathrm{r}^{\circledR}$ (National Institutes of Health, USA), a partir do qual foi determinada a densidade óptica óssea em milímetros de alumínio (mmAl). A região de interesse para a determinação da densidade óssea foi a diafisária dorsal média dos terceiros metacarpianos, coincidente com o sítio das falhas ósseas.

As imagens foram salvas em formato JPEG para o processamento no software. Com a ferramenta de seleção de área retangular do programa, selecionouse a área central de cada degrau da escala de alumínio e foi aferida a sua tonalidade média de cinzas (figura 14A), que poderia variar de 0 (totalmente negro) a 256 (totalmente branco). A sequência de medidas seguiu do $1^{\circ}$ degrau, mais fino

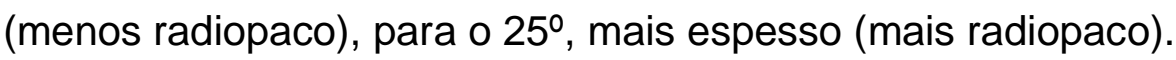

Estes valores foram armazenados sob a forma de tabelas para cada imagem analisada, afim de que cada uma tivesse a sua própria escala padrão, evitando a utilização de uma escala única para todas as imagens. Sabe-se que apesar da rigorosa padronização da técnica radiográfica, não é possível a obtenção de imagens idênticas em relação a variação de tonalidades de cinza. Dessa forma, buscou-se eliminar possíveis erros de medida decorrentes da não uniformidade das radiografias utilizando-se as escalas individuais.

Posteriormente, a ferramenta de seleção de área circular foi utilizada para selecionar a região das falhas ósseas e medir a sua tonalidade média de cinzas 
(figura 14B). Tais valores foram registrados nas tabelas juntamente com as informações de suas respectivas escalas de alumínio, para então serem convertidos à unidade de mmAl, mediante à utilização da função "tendência" do software Microsoft Office Excel $2010^{\circledR}$.

Figura 14 - Procedimentos para a determinação da densidade óptica radiográfica

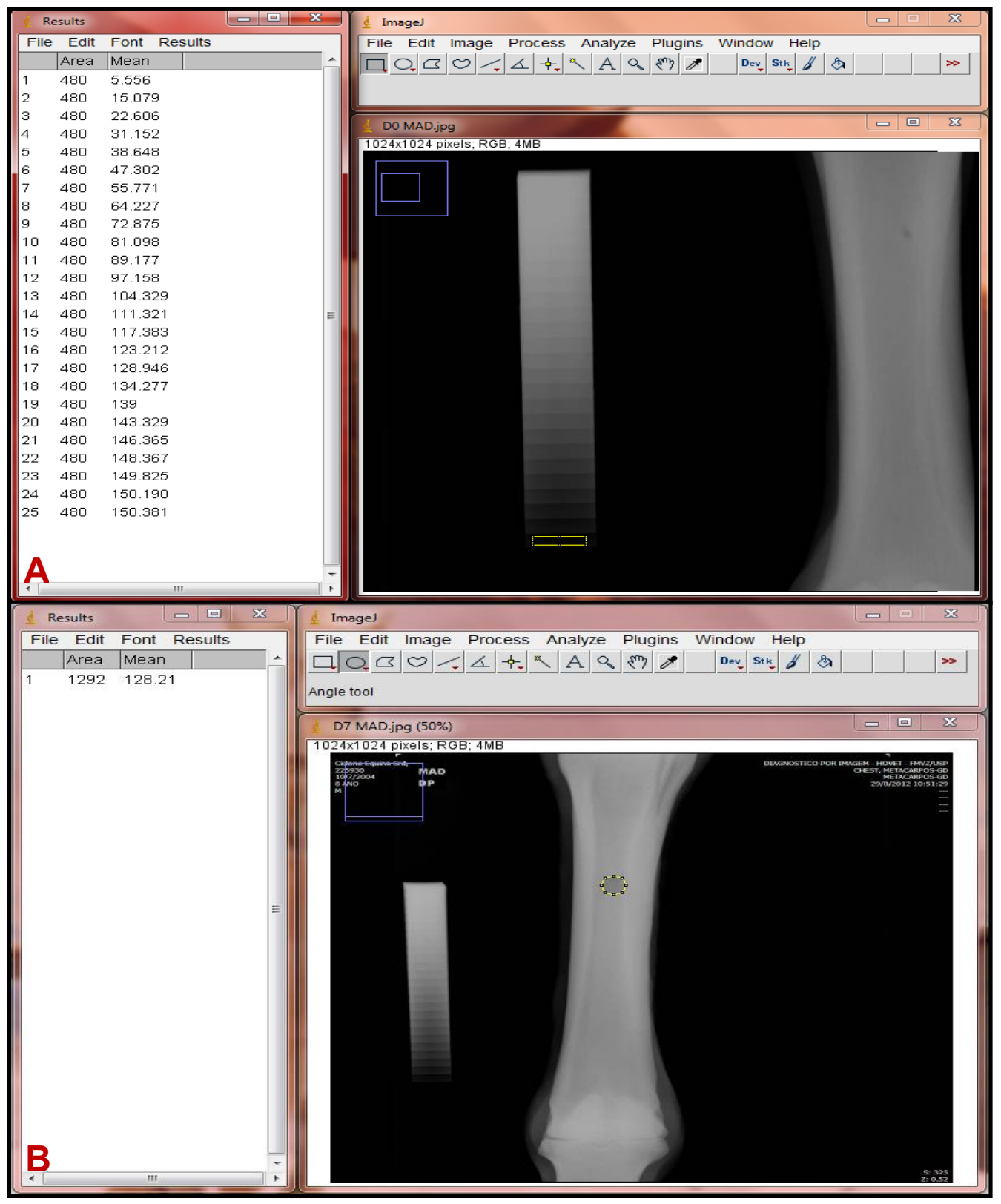

A - Determinação do tom de cinza médio de cada degrau da escala de alumínio; B Determinação do tom de cinza médio da falha óssea. Imagens do programa ImageJ ${ }^{\circledR}$. Fonte: Selim, M. B. (2013) 
Lembrando que a densidade óssea radiográfica foi aferida nos momentos préoperatório e nos $7^{\circ}, 1^{\circ}, 30^{\circ}, 60^{\circ}, 90^{\circ}$ e 120 dias após o procedimento cirúrgico. Devido à ausência da delimitação visual da falha óssea nas imagens radiográficas do momento pré-operatório, foi necessário o pareamento destas com as imagens obtidas no $7^{0}$ dia após o procedimento, para que a área selecionada durante a aferição da densidade coincidisse com a área onde estava localizada a falha óssea (figura 15).

Figura 15 - Procedimentos para a determinação da densidade óptica radiográfica

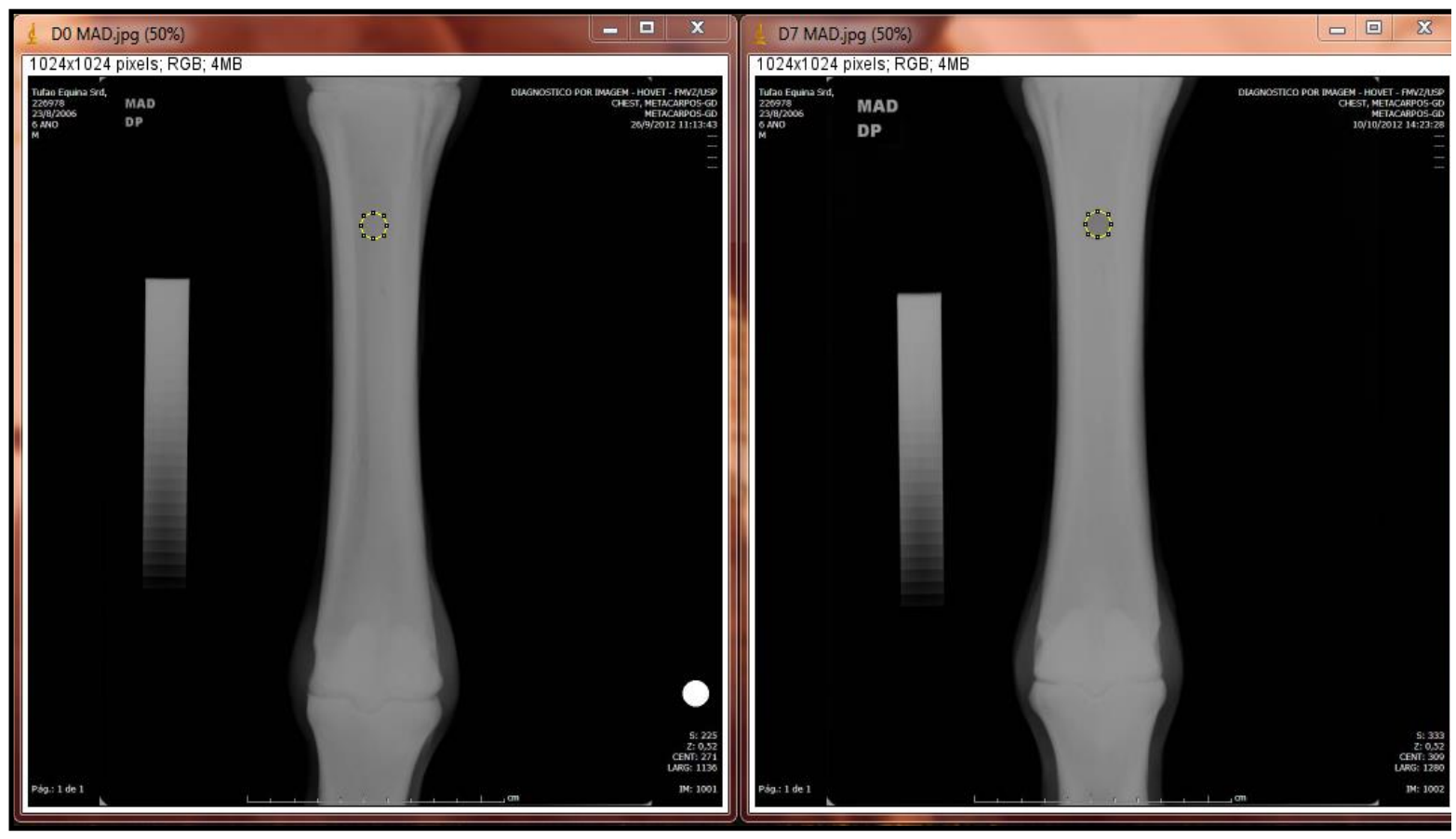

Pareamento das imagens dos momentos D0 e D7 para a delimitação da área da falha e de sua densidade no momento pré-cirúrgico. Imagens do programa Image $J^{\Theta^{3}}$.

Fonte: Selim, M. B. (2013)

Visando o maior aproveitamento das imagens radiográficas adquiridas, foi também realizado o acompanhamento e a comparação da cicatrização das falhas ósseas entre os membros sem preenchimento e os preenchidos com o polímero. Tal avaliação consistiu na aferição da profundidade, área, diâmetros transversal e longitudinal das falhas ósseas. 
Para a determinação destes parâmetros também foi utilizado o software ImageJ $1.46 r^{\circledR}$. A profundidade foi medida nas imagens de projeção latero-medial dos membros, enquanto que a área e os diâmetros transversal e longitudinal foram obtidos a partir das projeções dorso-palmares.

Inicialmente foi necessário calibrar o software a partir da escala contida nas imagens radiográficas, a qual determinava que $1 \mathrm{~cm}$ equivalia a 34 pixels. $\mathrm{Na}$ projeção lateromedial foi traçada uma linha reta a partir do bordo proximal da falha óssea até o seu limite visível no canal medular (figura 16). A distância determinada pelo programa (em centímetros) era então registrada em uma tabela como a profundidade da falha óssea.

Figura 16 - Mensurações radiográficas

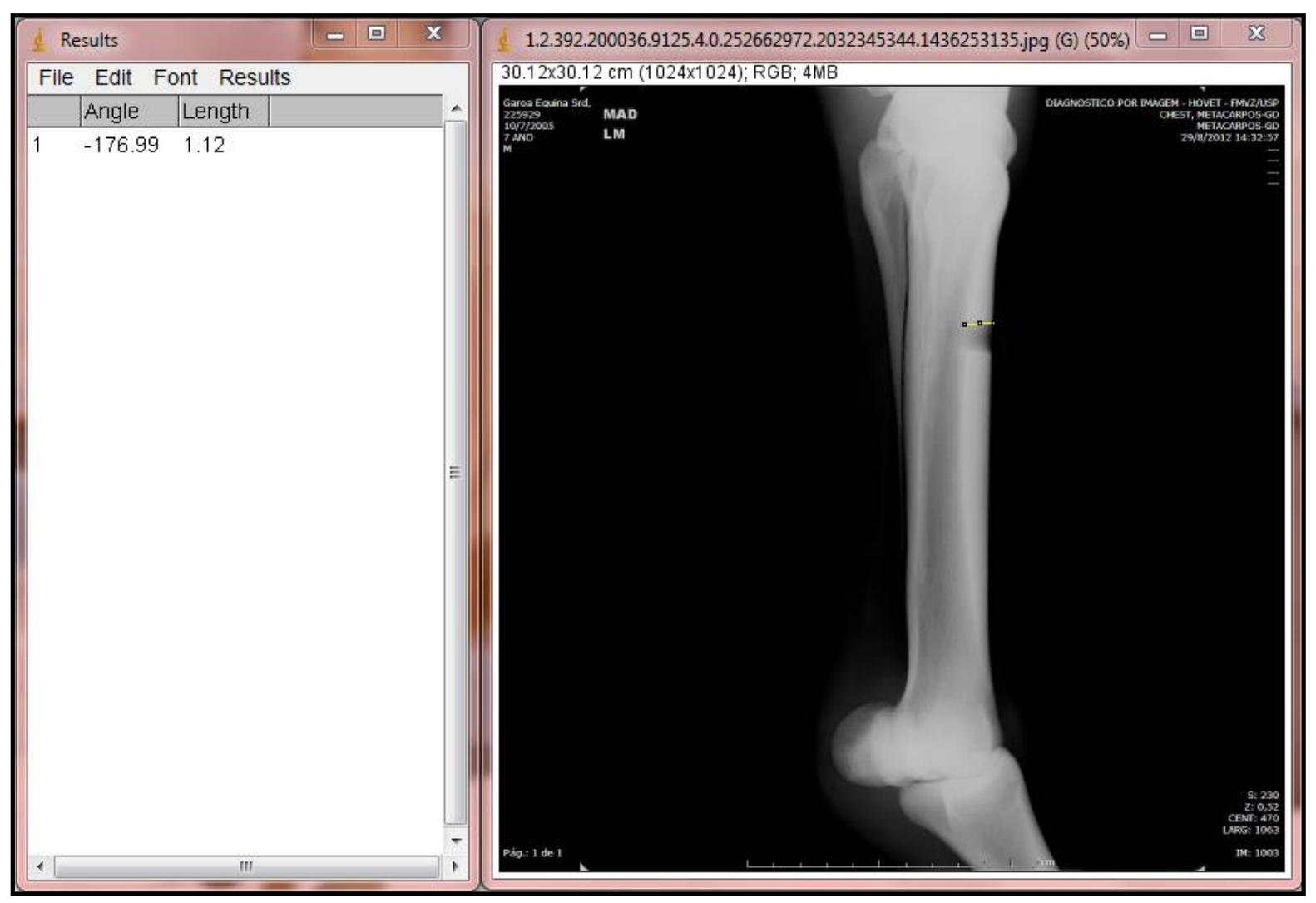

Determinação da profundidade da falha óssea a partir de imagem radiográfica na projeção lateromedial. Imagem do programa Image ${ }^{\circledR}$.

Fonte: Selim, M. B. (2013)

Considerando a projeção dorso-palmar, também foram traçadas duas linhas retas e perpendiculares entre si nos limites das falhas, as quais compreendiam os 
seus diâmetros transversal e longitudinal (figuras 17 e 18). Para a determinação da área das falhas foi utilizada a ferramenta de seleção de área circular do software (figura 19). Os valores obtidos nestas etapas foram resgistrados na mesma tabela da profundidade.

Figura 17 - Mensurações Radiográficas

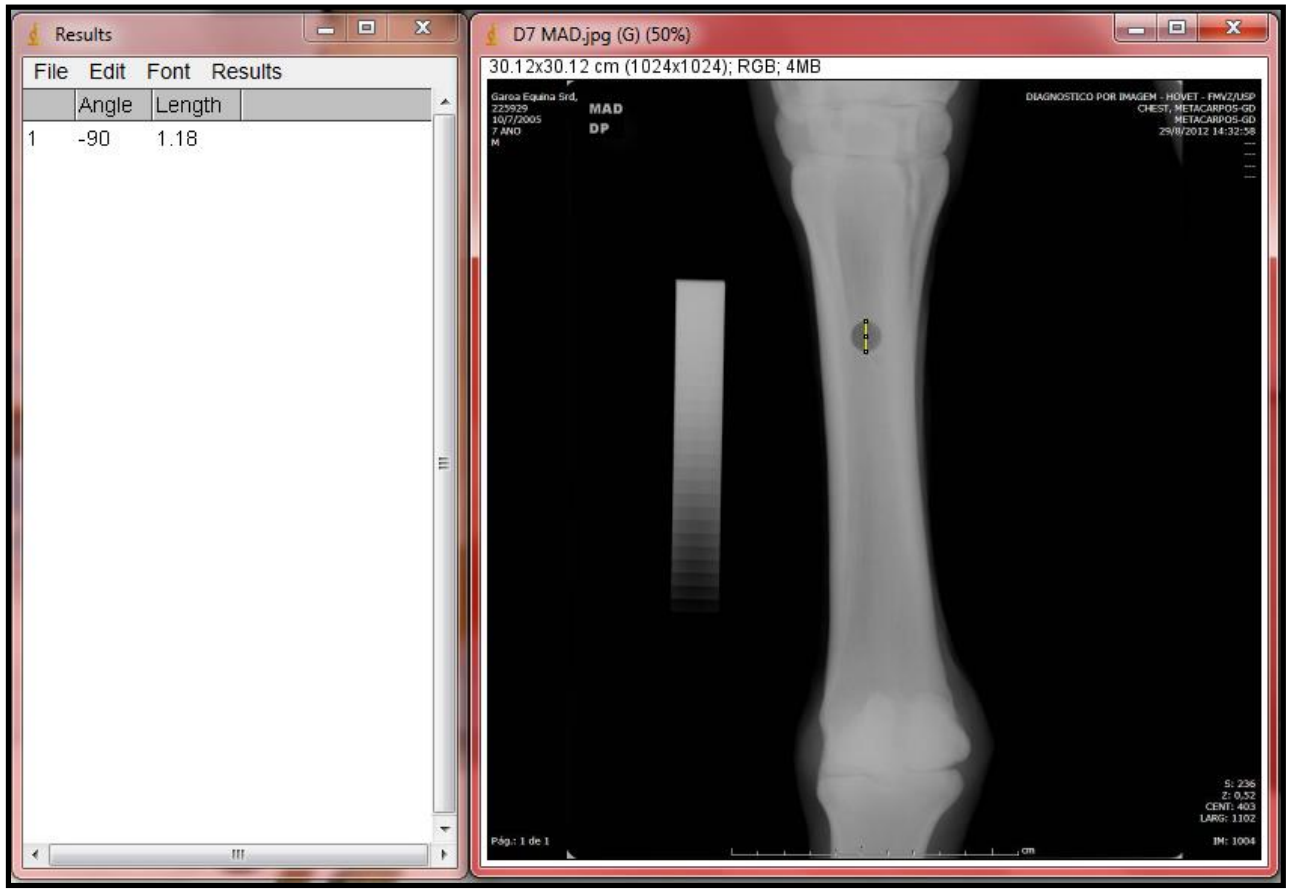

Determinação do diâmetro longitudinal da falha óssea a partir de imagem radiográfica na projeção dorsopalmar. Imagem do programa Image ${ }^{\circledR}$.

Fonte: Selim, M. B. (2013)

Os diâmetros foram dados em centímetros $(\mathrm{cm})$ e a área em centímetros quadrados $\left(\mathrm{cm}^{2}\right)$. As medidas descritas foram feitas nos momentos $7^{\circ}$ e $120^{\circ}$ dias de pós-operatório com o objetivo de comparar a porcentagem de diminuição das mesmas entre as falhas controle e as preenchidas com o polímero. Os cálculos foram realizados com o auxílio do software Microsoft Office Excel $2010^{\circledR}$. 
Figura 18 - Mensurações radiográficas

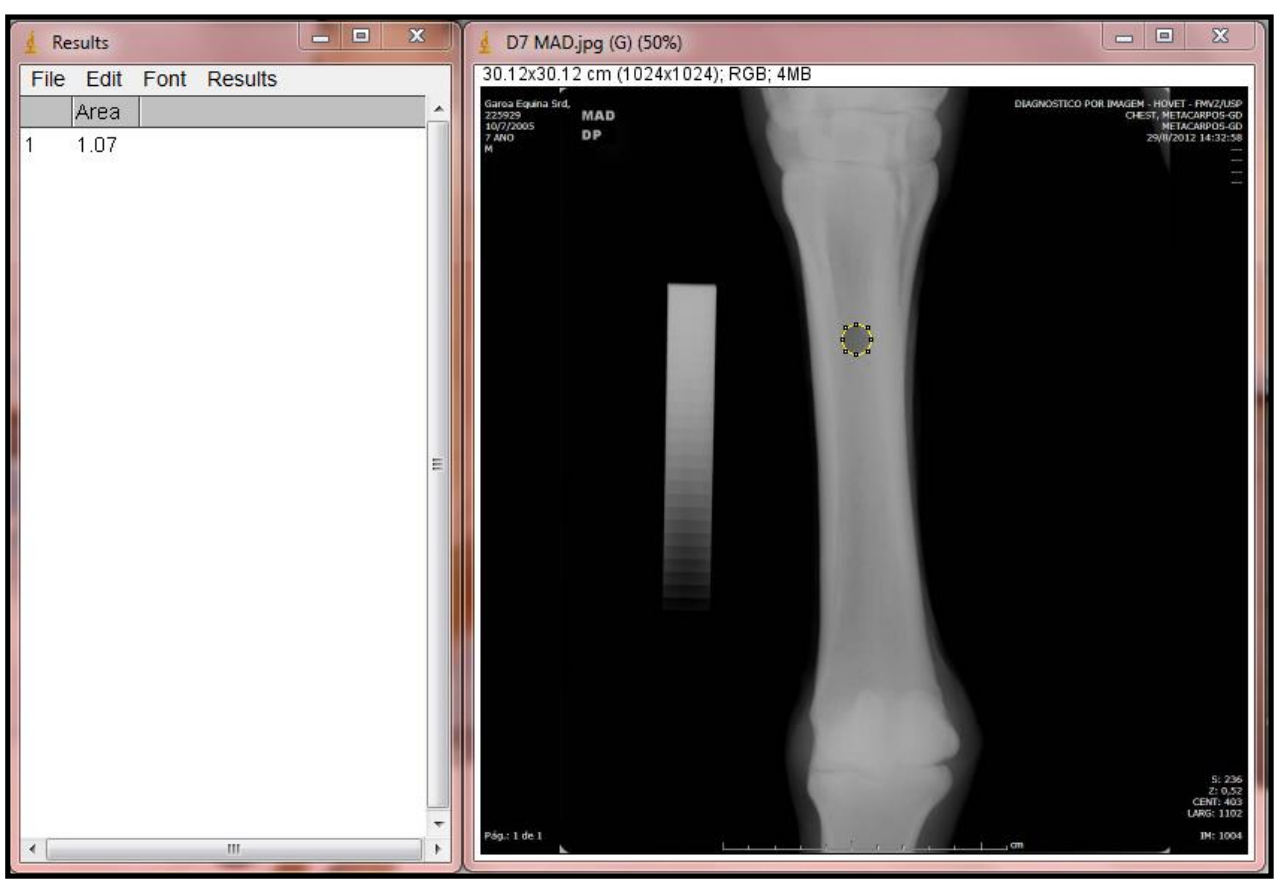

Determinação do diâmetro transversal da falha óssea a partir de imagem radiográfica na projeção dorsopalmar. Imagem do programa Image $J^{\circledR}$.

Fonte: Selim, M. B. (2013)

Figura 19 - Mensurações radiográficas

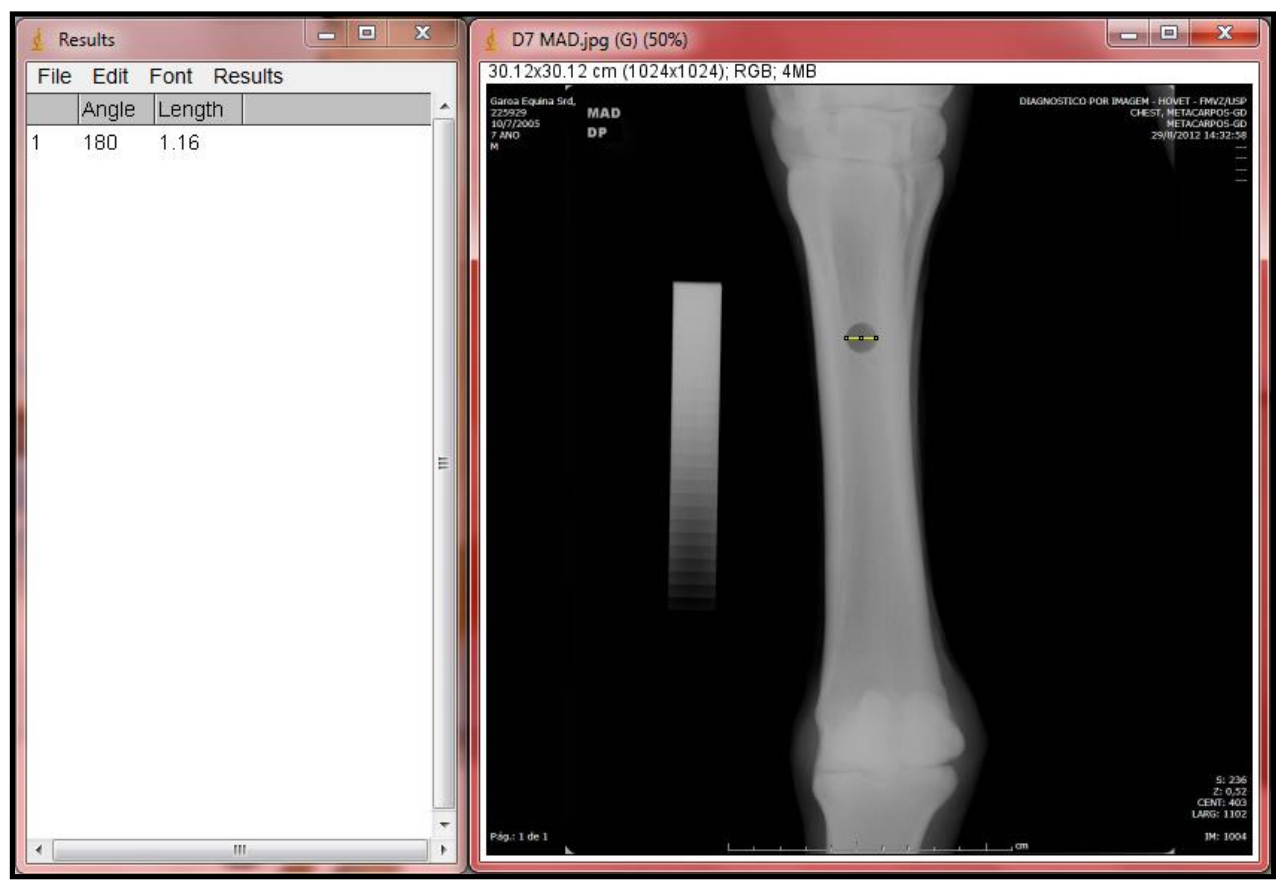

Determinação da área da falha óssea a partir de imagem radiográfica na projeção dorsopalmar. Imagem do programa Image ${ }^{\circledR}$.

Fonte: Selim, M. B. (2013) 
As imagens radiográficas também foram analisadas qualitativamente quanto à estabilidade dos implantes no leito receptor e presença reações de osteólise e/ou de proliferação óssea acentuadas.

\subsubsection{Avaliação por microscopia óptica de luz (MOL)}

A avaliação por MOL foi realizada em parceria com o Departamento de Estomatologia da Faculdade de Odontologia da Universidade de São Paulo, campus da cidade de São Paulo, sob a orientção da Prof. Dra. Luciana Corrêa.

As amostras foram mantidas calcificadas e processadas seguindo o protocolo de fixação, desidratação, diafanização, inclusão em resina de metilmetacrilato, microtomia, desgaste, montagem das lâminas e coloração. A coloração utilizada foi a Stevenel's Blue. O protocolo de processamento destas amostras encontra-se detalhadamente descrito nos apêndices do trabalho (Apêndice A).

O processamento das amostras foi realizado no Laboratório de Biologia dos Tecidos Mineralizados do Departamento de Anatomia Humana do Instituto de Ciências Biomédicas da Universidade de São Paulo.

As lâminas foram analisadas em microscópio óptico de luz da marca Leica, modelo DM2500, utilizando as lentes objetivas de 5x e 10x. Com o auxílio do software Leica Aplication Suite ${ }^{\circledR}$ (LAS V4.1) foi feita a varredura das lâminas e registrou-se imagens do número máximo de campos dentro de cada corte. Tais imagens foram analisadas com o auxílio do programa WCIF ImageJ 1.37a ${ }^{\circledR}$ (National Institutes of Health, USA), a partir do qual foram determinadas as áreas total e de osso neoformado em $\mu \mathrm{m}^{2}$ de cada campo.

Após a calibração do software de acordo com a lente do microscópio utilizada durante a aquisição das imagens, foi utilizada a ferramenta de seleção livre para contornar e medir a área total e a de osso neoformado dos campos (figuras 20 e 21). O valores obtidos foram registrados em uma tabela e submetidos a cálculos com o auxílio do software Microsoft Office Excel $2010^{\circledR}$. 
Figura 20 - Avaliação histológica por microscopia óptica de luz

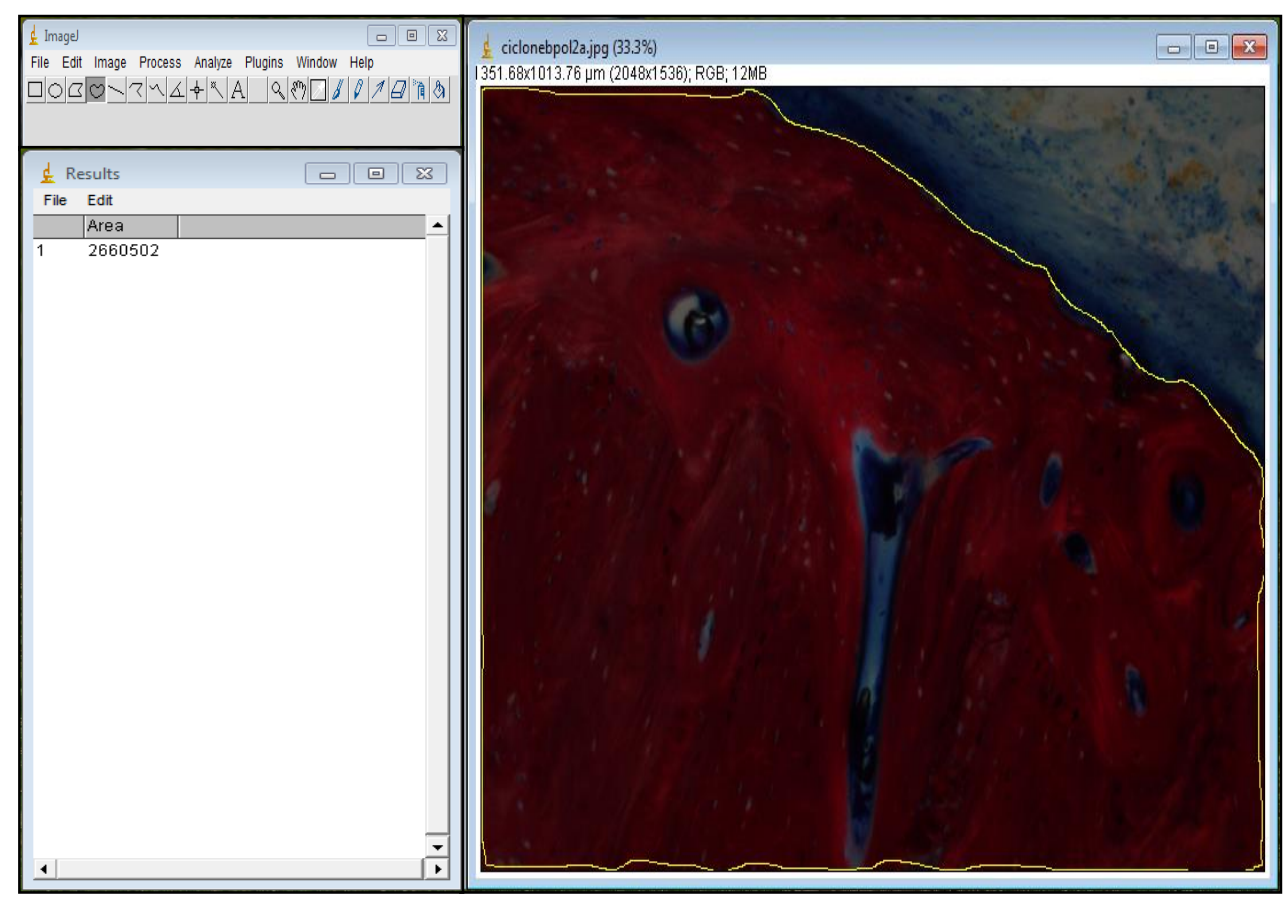

Determinação da área total de tecido ósseo presente no campo. Imagem do programa WCIF ImageJ 1.37a ${ }^{\circledR}$.

Fonte: Selim, M. B. (2013)

Figura 21 - Avaliação histológica por microscopia óptica de luz

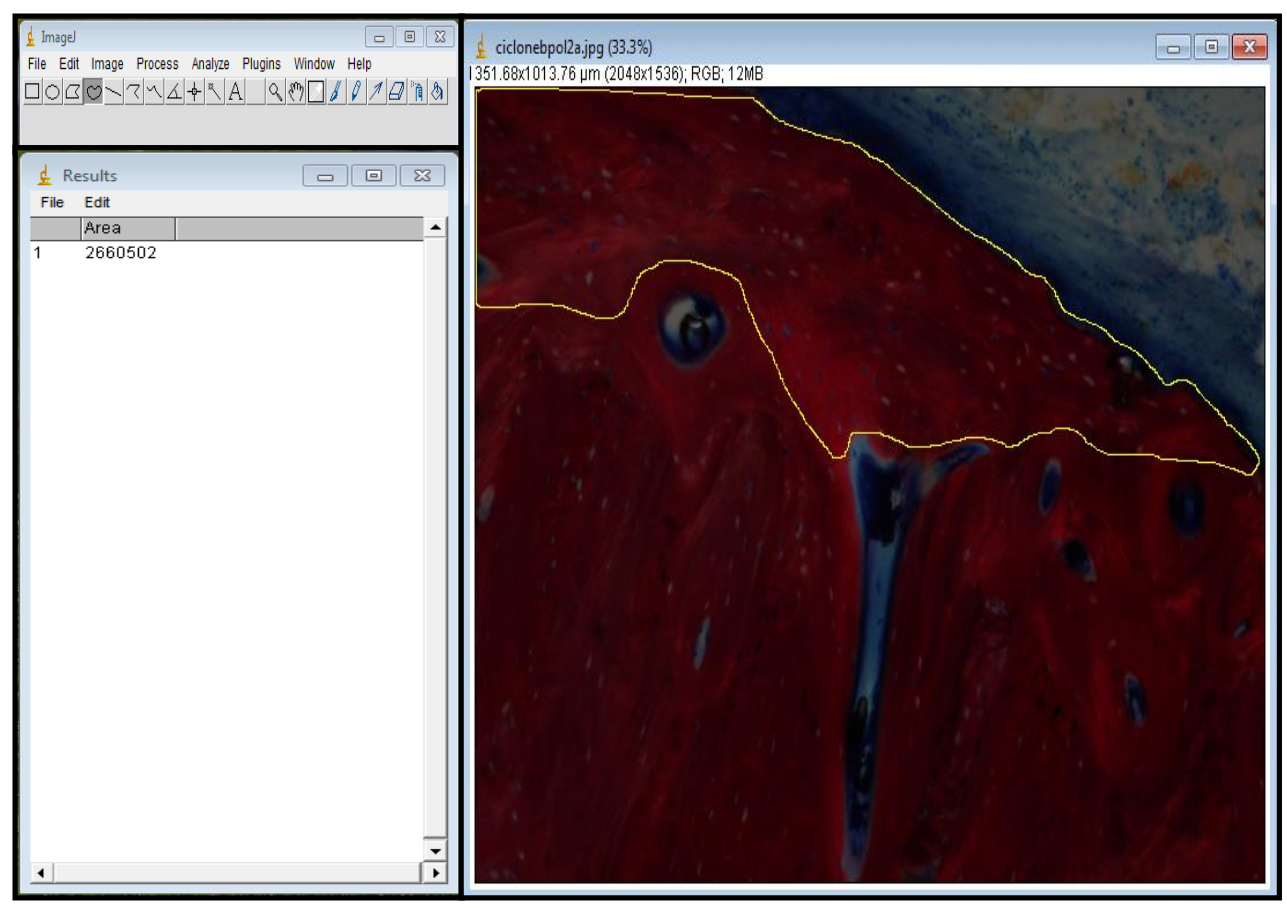

Determinação da área de tecido ósseo neoformado presente no campo. Imagem do programa WCIF ImageJ $1.37 a^{\circledR}$.

Fonte: Selim, M. B. (2013) 
A partir dos cálculos foi determinada a relação entre as áreas de tecido ósseo neoformado/área total na presença e ausência do substituto ósseo estudado. Tal relação possibilitou avaliar quantitativamente a resposta do organismo frente ao biopolímero.

\subsubsection{Avaliação por microscopia eletrônica de varredura (MEV)}

A avaliação por MEV foi realizada em parceria com o Departamento de Biomateriais e Biologia Oral, da Faculdade de Odontologia da Universidade de São Paulo, campus da cidade de São Paulo, sob a orientção do Prof. Dr. Victor Elias Arana-Chavez.

Os fragmentos ósseos removidos durante a confecção das falhas ósseas e biópsias foram preparados e visualizados no microscópio eletrônico de varredura LEO 430, operando com aceleração de voltagem de $15 \mathrm{kV}$. O protocolo de processamento das amostras consistiu em fixação, lavagem, remoção de material orgânico, lavagem, desidratação, secagem, montagem e metalização. Tais etapas estão descritas detalhadamente na seção de apêndices do trabalho (Apêndice B).

Cada amostra foi observada ao MEV e descrita qualitativamente considerando-se a sua morfologia. 


\section{RESULTADOS}

\subsection{AVALIAÇÃO CLÍNICA E DE CLAUDICAÇÃO}

Os parâmetros fisiológicos dos animais se mantiveram constantes durante todo o experimento, apresentando pequenas variações nos primeiros dias após os procedimentos cirúrgicos, como leve aumento das frequências cardíaca (média de 31,5 bpm no pré cirúrgico, e de 41,7bpm no pós imediato) e respiratória (média de 16 mpm no pré cirúrgico, e de 17,7 mpm no pós imediato), mas sempre dentro dos intervalos fisiológicosda espécie.

Com relação ao exame local, não foram observadas complicações relacionadas à ferida cirúrgica. Inicialmente notou-se edema e aumento de temperatura discretos da região, em ambos os membros e em igual intensidade, compatíveis com o processo inflamatório natural após uma lesão; sendo que estes apresentavam resolução até o momento da retirada dos pontos, aos 15 dias de pósoperatório.

Os animais apresentavam dor leve à palpação da região operada em ambos os membros, sugerindo que esta seria associada especificamente à presença da lesão óssea e não do polímero implantado. Cerca de 30 dias após a indução das falhas ósseas, tal desconforto havia reduzido significantemente e até desaparecido em alguns animais, não sendo considerado clinicamente relevante.

Previamente ao procedimento os animais não apresentavam claudicação (grau 0). Até a avaliação do 30 dia após o procedimento os animais apresentaram os maiores escores de claudicação, variando entre 2 e 3. Deste período em diante, a graduação tendeu a diminuir até o 120 dia; tornando-se quase imperceptível, sendo classificada como 1. Não foi possível associar os maiores escores de claudicação à presença do polímero, pois estes também ocorreram nos membros sem preenchimento. 


\subsection{DENSITOMETRIA ÓPTICARADIOGRÁFICA E MENSURAÇÕES RADIOGRÁFICAS}

O resultados obtidos na avaliação densitométrica estão descritos na tabela 1, para os membros controle (Cont) e preenchidos com o biopolímero de poliuretana de mamona (Pol), nos diferentes momentos pós- operatórios (D0, D7, D15, D30, D60, D90 e D120). Também são apresentadas as médias dos valores obtidos em cada período para cada um dos tratamentos.

Tabela 1 - Densidade óptica radiográfica (em mmAl) das falhas ósseas preenchidas com polímero (Pol) e sem preenchimento (Cont), em diferentes momentos pós operatórios - São Paulo - 2011 a 2013

\begin{tabular}{cccccccccccccccc}
\hline \multirow{2}{*}{ Momento } & \multicolumn{2}{c}{ Equino 1 } & \multicolumn{2}{c}{ Equino 2 } & \multicolumn{2}{c}{ Equino 3 } & \multicolumn{2}{c}{ Equino 4 } & \multicolumn{2}{c}{ Equino 5 } & \multicolumn{2}{c}{ Equino 6} & \multicolumn{2}{c}{ Média } \\
& Pol & Cont & Pol & Cont & Pol & Cont & Pol & Cont & Pol & Cont & Pol & Cont & Pol & Cont \\
\hline D0 & 18 & 18 & 18 & 18 & 20 & 19 & 15 & 16 & 18 & 18 & 16 & 15 & 17,5 & 17,3 \\
D7 & 8 & 12 & 14 & 16 & 16 & 15 & 12 & 13 & 16 & 15 & 13 & 11 & 13,2 & 13,7 \\
D15 & 9 & 12 & 13 & 15 & 17 & 17 & 12 & 13 & 15 & 13 & 13 & 12 & 13,2 & 13,7 \\
D30 & 9 & 14 & 12 & 15 & 17 & 16 & 11 & 13 & 15 & 14 & 12 & 15 & 12,7 & 14,5 \\
D60 & 11 & 13 & 12 & 15 & 17 & 15 & 12 & 13 & 15 & 16 & 13 & 15 & 13,3 & 14,5 \\
D90 & 12 & 15 & 14 & 17 & 16 & 17 & 12 & 13 & 16 & 18 & 13 & 15 & 13,8 & 15,8 \\
D120 & 12 & 16 & 15 & 18 & 16 & 17 & 13 & 14 & 16 & 18 & 13 & 15 & 14,2 & 16,3 \\
\hline
\end{tabular}

A partir dos valores de densidade médios de cada grupo, elaborou-se o gráfico da Figura 22 para facilitar a interpretação da evolução da densidade óptica radiográfica durante o período de avaliação.

Figura 22 - Evolução da densidade óptica radiográfica média, nos grupos polímero e controle, de acordo o período pós operatório - São Paulo - 2011 a 2013

\section{Densidade óptica média x Tempo}

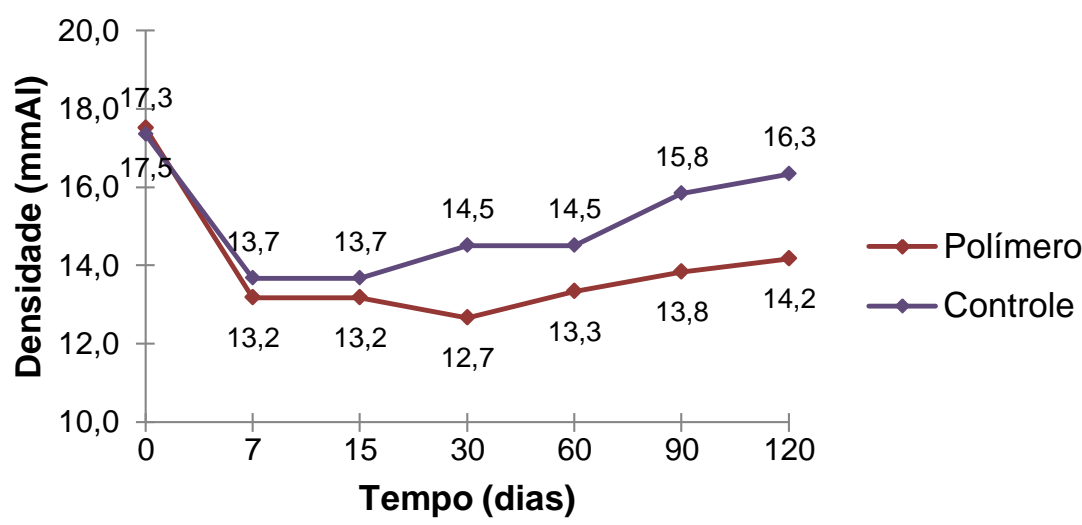

Fonte: Selim, M. B. (2013) 
De acordo com o gráfico da figura 22 foi possível observar que os valores iniciais da densidade (em D0) sofreram queda abrupta em D7, tanto no grupo controle como no do polímero, devido à retirada de material para a confecção das falhas ósseas. Considerando-se os membros controle, os valores de densidade tendem a aumentar gradativamente, e se aproximar dos valores iniciais ao final dos 120 dias de avaliação. Entretanto, no caso dos membros preenchidos com o polímero, observa-se uma tendência à estabilização da densidade após a queda abrupta, com aumento discreto dos valores quando se chega aos 120 dias de avaliação.

As tabelas 2, 3, 4 e 5 contêm os valores das mensurações de diâmetro transversal, diâmetro longitudinal, área e profundidade das falhas ósseas, respectivamente, efetuadas a partir das imagens radiográficas obtidas 7 e 120 dias após os procedimentos cirúrgicos. Nelas também podem ser observados os percentuais de diminuição destes parâmetros dentro do período de avaliação, bem como a comparação entre as mensurações das falhas preenchidas com polímero e das não preenchidas (controle).

Tabela 2 - Diâmetro transversal das falhas ósseas aos 7 e 120 dias após o procedimento cirúrgico - São Paulo - 2011 a 2013

\begin{tabular}{cccccc}
\hline \multirow{2}{*}{ Animal } & Momento & \multicolumn{2}{c}{ Diâmetro transversal $(\mathrm{cm})$} & \multicolumn{2}{c}{$\%$ Diminuição } \\
& & Polímero & Controle & Polímero & Controle \\
\hline \multirow{2}{*}{ Equino 1 } & $\mathrm{D} 7$ & 1,20 & 1,16 & \multirow{2}{*}{$15,83 \%$} & $49,74 \%$ \\
& $\mathrm{D} 120$ & 1,01 & 0,58 & & \\
Equino 2 & $\mathrm{D} 7$ & 1,13 & 1,23 & $1,77 \%$ & $56,34 \%$ \\
& $\mathrm{D} 120$ & 1,11 & 0,54 & & \\
Equino 3 & $\mathrm{D} 7$ & 1,03 & 1,17 & \multirow{2}{*}{$0,00 \%$} & $23,42 \%$ \\
& $\mathrm{D} 120$ & 1,03 & 0,90 & & \\
Equino 4 & $\mathrm{D} 7$ & 1,15 & 1,15 & \multirow{2}{*}{$5,22 \%$} & $53,22 \%$ \\
& $\mathrm{D} 120$ & 1,09 & 0,54 & & \\
Equino 5 & $\mathrm{D} 7$ & 1,21 & 1,15 & \multirow{2}{*}{$16,53 \%$} & $86,09 \%$ \\
& $\mathrm{D} 120$ & 1,01 & 0,16 & & \\
Equino 6 & $\mathrm{D} 7$ & 1,17 & 1,13 & \multirow{2}{*}{$6,84 \%$} & $89,47 \%$ \\
\hline
\end{tabular}


Tabela 3 - Diâmetro longitudinal das falhas ósseas aos 7 e 120 dias após o procedimento cirúrgico - São Paulo - 2011 a 2013

\begin{tabular}{cccccc}
\hline \multirow{2}{*}{ Animal } & Momento & \multicolumn{2}{c}{ Diâmetro Longitudinal $(\mathrm{cm})$} & \multicolumn{2}{c}{ \% Diminuição } \\
& & Polímero & Controle & Polímero & Controle \\
\hline \multirow{2}{*}{ Equino 1 } & D7 & 1,19 & 1,12 & $9,24 \%$ & $20,54 \%$ \\
& D120 & 1,08 & 0,89 & & \\
Equino 2 & D7 & 1,16 & 1,19 & $4,31 \%$ & $90,76 \%$ \\
& D120 & 1,11 & 0,11 & & \\
Equino 3 & D7 & 1,15 & 1,11 & \multirow{2}{*}{$0,00 \%$} & $3,60 \%$ \\
& D120 & 1,15 & 1,07 & & \\
Equino 4 & D7 & 1,15 & 1,17 & \multirow{2}{*}{$35,74 \%$} & \\
& D120 & 1,13 & 0,75 & & \\
Equino 5 & D7 & 1,21 & 1,19 & \multirow{2}{*}{$9,92 \%$} & \\
& D120 & 1,09 & 0,43 & & \\
Equino 6 & D7 & 1,21 & 1,17 & \multirow{2}{*}{$4,96 \%$} & \\
& D120 & 1,15 & 0,47 & & \\
\hline
\end{tabular}

Tabela 4 - Área das falhas ósseas aos 7 e 120 dias após o procedimento cirúrgico - São Paulo 2011 a 2013

\begin{tabular}{cccccc}
\hline \multirow{2}{*}{ Animal } & Momento & \multicolumn{2}{c}{ Área Falha $\left(\mathrm{cm}^{2}\right)$} & \multicolumn{2}{c}{$\%$ Diminuição } \\
& & Polímero & Controle & Polímero & Controle \\
\hline \multirow{2}{*}{ Equino 1 } & $\mathrm{D} 7$ & 1,04 & 1,01 & \multirow{2}{*}{$25,96 \%$} & $67,33 \%$ \\
& $\mathrm{D} 120$ & 0,77 & 0,33 & & \\
Equino 2 & $\mathrm{D} 7$ & 0,91 & 1,06 & $3,30 \%$ & $94,34 \%$ \\
& $\mathrm{D} 120$ & 0,88 & 0,06 & & \\
Equino 3 & $\mathrm{D} 7$ & 0,96 & 1,07 & \multirow{2}{*}{$1,04 \%$} & $28,97 \%$ \\
& $\mathrm{D} 120$ & 0,95 & 0,76 & & \\
Equino 4 & $\mathrm{D} 7$ & 0,98 & 1,06 & \multirow{2}{*}{$0,00 \%$} & $68,87 \%$ \\
& $\mathrm{D} 120$ & 0,98 & 0,33 & & \\
Equino 5 & $\mathrm{D} 7$ & 1,12 & 1,12 & \multirow{2}{*}{$18,75 \%$} & $92,86 \%$ \\
& $\mathrm{D} 120$ & 0,91 & 0,08 & & \\
Equino 6 & $\mathrm{D} 7$ & 1,15 & 1,06 & \multirow{2}{*}{$14,78 \%$} & $95,28 \%$ \\
& $\mathrm{D} 120$ & 0,98 & 0,05 & & \\
\hline
\end{tabular}


Tabela 5 - Profundidade das falhas ósseas aos 7 e 120 dias após o procedimento cirúrgico - São Paulo - 2011 a 2013

\begin{tabular}{cccccc}
\hline \multirow{2}{*}{ Animal } & Momento & \multicolumn{2}{c}{ Profundidade Falha (cm) } & \multicolumn{2}{c}{ \% Diminuição } \\
& & Polímero & Controle & Polímero & Controle \\
\hline \multirow{2}{*}{ Equino 1 } & D7 & 0,88 & 0,87 & $5,68 \%$ & $64,37 \%$ \\
& D120 & 0,83 & 0,31 & & \\
Equino 2 & D7 & 0,86 & 1,03 & $22,09 \%$ & $92,23 \%$ \\
& D120 & 0,67 & 0,08 & & \\
Equino 3 & D7 & 0,88 & 0,99 & \multirow{2}{*}{$5,68 \%$} & $30,30 \%$ \\
& D120 & 0,83 & 0,69 & & \\
Equino 4 & D7 & 0,97 & 0,97 & \multirow{2}{*}{$4,12 \%$} & $30,93 \%$ \\
& D120 & 0,93 & 0,67 & & \\
Equino 5 & $\mathrm{D} 7$ & 0,96 & 0,95 & \multirow{2}{*}{$51,04 \%$} & $86,32 \%$ \\
& $\mathrm{D} 120$ & 0,47 & 0,13 & & \\
Equino 6 & $\mathrm{D} 7$ & 0,68 & 0,71 & \multirow{2}{*}{$7,35 \%$} & $76,06 \%$ \\
& $\mathrm{D} 120$ & 0,63 & 0,17 & & \\
\hline
\end{tabular}

Com relação às mensurações radiográficas das falhas ósseas, constatou-se que, na presença do polímero, tais parâmetros sofriam diminuição discreta quando comparados aos das falhas sem preenchimento.

Todos as variáveis apresentadas anteriormente foram analisadas estatisticamente através do programa IBM SPSS Statistics V.18.0 ${ }^{\circledR}$, e foram descritas pelas suas respectivas médias, desvios padrão, valores máximos e mínimos. Para a comparação entre os grupos controle e polímero, e entre os diferentes momentos de coleta foi utilizado o teste de Wilcoxon considerando-se um nível de significância de $5 \%$.

As tabelas $6,7,8,9$, e 10 apresentam os descritores das variáveis analisadas. 
Tabela 6 - Descritores da variável densidade radiográfica dos grupos polímero e controle para os diferentes momentos de coleta - São Paulo - 2011 a 2013

\begin{tabular}{lccccc}
\hline \multicolumn{1}{c}{ Variável } & Média & Mediana & Desvio padrão & Mínimo & Máximo \\
\hline Densidade radiográfica polímero D0 & 17,5 & 18 & 1,761 & 15 & 20 \\
Densidade radiográfica polímero D7 & 13,17 & 13,5 & 2,994 & 8 & 16 \\
Densidade radiográfica polímero D15 & 13,17 & 13 & 2,714 & 9 & 17 \\
Densidade radiográfica polímero D30 & 12,67 & 12 & 2,875 & 9 & 17 \\
Densidade radiográfica polímero D60 & 13,33 & 12,5 & 2,251 & 11 & 17 \\
Densidade radiográfica polímero D90 & 13,83 & 13,5 & 1,835 & 12 & 16 \\
Densidade radiográfica polímero D120 & 14,17 & 14 & 1,722 & 12 & 16 \\
Densidade radiográfica controle D0 & 17,33 & 18 & 1,506 & 15 & 19 \\
Densidade radiográfica controle D7 & 13,67 & 14 & 1,966 & 11 & 16 \\
Densidade radiográfica controle D15 & 13,67 & 13 & 1,966 & 12 & 17 \\
Densidade radiográfica controle D30 & 14,5 & 14,5 & 1,049 & 13 & 16 \\
Densidade radiográfica controle D60 & 14,5 & 15 & 1,225 & 13 & 16 \\
Densidade radiográfica controle D90 & 15,83 & 16 & 1,835 & 13 & 18 \\
Densidade radiográfica controle D120 & 16,33 & 16,5 & 1,633 & 14 & 18 \\
\hline
\end{tabular}

Tabela 7 - Descritores da variável diâmetro transversal (D Trans) nos grupos polímero (Pol) e controle (Cont) nos momentos D7 e D120 - São Paulo - 2011 a 2013

\begin{tabular}{lcccccc}
\hline Descritor & $\begin{array}{c}\text { D Trans } \\
\text { Pol D7 }\end{array}$ & $\begin{array}{c}\text { D Trans } \\
\text { Cont D7 }\end{array}$ & $\begin{array}{c}\text { D Trans } \\
\text { Pol D120 }\end{array}$ & $\begin{array}{c}\text { D Trans } \\
\text { Cont D120 }\end{array}$ & $\begin{array}{c}\% \\
\text { Diminuição } \\
\text { Pol }\end{array}$ & $\begin{array}{c}\% \\
\text { Diminuição } \\
\text { Cont }\end{array}$ \\
\hline $\mathrm{N}$ & 6 & 6 & 6 & 6 & 6 & 6 \\
Média & 1,14 & 1,16 & 1,05 & 0,47 & $7,69 \%$ & $59,71 \%$ \\
Mediana & 1,16 & 1,15 & 1,06 & 0,53 & $6,03 \%$ & $54,78 \%$ \\
Desvio padrão & 0,06 & 0,03 & 0,04 & 0,29 & $7,00 \%$ & $24,70 \%$ \\
Mínimo & 1,03 & 1,13 & 1,01 & 0,11 & $0,00 \%$ & $23,42 \%$ \\
Máximo & 1,21 & 1,23 & 1,11 & 0,89 & $16,53 \%$ & $89,47 \%$ \\
\hline
\end{tabular}


Tabela 8 - Descritores da variável diâmetro longitudinal (D Long) nos grupos polímero (Pol) e controle (Cont) nos momentos D7 e D120 - São Paulo - 2011 a 2013

\begin{tabular}{lcccccc}
\hline Descritor & $\begin{array}{c}\text { D Long } \\
\text { Pol D7 }\end{array}$ & $\begin{array}{c}\text { D Long } \\
\text { Cont D7 }\end{array}$ & $\begin{array}{c}\text { D Long } \\
\text { Pol D120 }\end{array}$ & $\begin{array}{c}\text { D Long } \\
\text { Cont D120 }\end{array}$ & $\begin{array}{c}\% \\
\text { Diminuição } \\
\text { Pol }\end{array}$ & $\begin{array}{c}\% \\
\text { Diminuição } \\
\text { Cont }\end{array}$ \\
\hline Média & 6 & 6 & 6 & 6 & 6 & 6 \\
Mediana & 1,17 & 1,15 & 1,11 & 0,62 & $5,02 \%$ & $45,75 \%$ \\
Desvio padrão & 1,17 & 1,17 & 1,12 & 0,61 & $4,63 \%$ & $47,86 \%$ \\
Mínimo & 0,02 & 0,03 & 0,03 & 0,34 & $3,95 \%$ & $31,81 \%$ \\
Máximo & 1,15 & 1,11 & 1,08 & 0,11 & $0,00 \%$ & $3,60 \%$ \\
\hline
\end{tabular}

Tabela 9 - Descritores da variável área nos grupos polímero (Pol) e controle (Cont) nos momentos D7 e D120 - São Paulo - 2011 a 2013

\begin{tabular}{lcccccc}
\hline Descritor & $\begin{array}{c}\text { Área Pol } \\
\text { D7 }\end{array}$ & $\begin{array}{c}\text { Área Cont } \\
\text { D7 }\end{array}$ & $\begin{array}{c}\text { Área Pol } \\
\text { D120 }\end{array}$ & $\begin{array}{c}\text { Área Cont } \\
\text { D120 }\end{array}$ & $\begin{array}{c}\% \\
\text { Diminuição } \\
\text { Pol }\end{array}$ & $\begin{array}{c}\% \\
\text { Diminuição } \\
\text { Cont }\end{array}$ \\
\hline N & 6 & 6 & 6 & 6 & 6 & 6 \\
Média & 1,02 & 1,06 & 0,91 & 0,26 & $10,63 \%$ & $74,60 \%$ \\
Mediana & 1,01 & 1,06 & 0,93 & 0,20 & $9,04 \%$ & $80,86 \%$ \\
Desvio padrão & 0,09 & 0,03 & 0,07 & 0,27 & $10,74 \%$ & $25,76 \%$ \\
Mínimo & 0,91 & 1,01 & 0,77 & 0,05 & $0,00 \%$ & $28,97 \%$ \\
Máximo & 1,15 & 1,12 & 0,98 & 0,76 & $25,96 \%$ & $95,28 \%$ \\
\hline
\end{tabular}

Tabela 10 - Descritores da variável profundidade (Prof) nos grupos polímero (Pol) e controle (Cont) nos momentos D7 e D120 - São Paulo - 2011 a 2013

\begin{tabular}{lcccccc}
\hline Descritor & $\begin{array}{c}\text { Prof Pol } \\
\text { D7 }\end{array}$ & $\begin{array}{c}\text { Prof Cont } \\
\text { D7 }\end{array}$ & $\begin{array}{c}\text { Prof Pol } \\
\text { D120 }\end{array}$ & $\begin{array}{c}\text { Prof Cont } \\
\text { D120 }\end{array}$ & $\begin{array}{c}\% \\
\text { Diminuição } \\
\text { Pol }\end{array}$ & $\begin{array}{c}\text { \% } \\
\text { Diminuição } \\
\text { Cont }\end{array}$ \\
\hline $\mathrm{N}$ & 6 & 6 & 6 & 6 & 6 & 6 \\
Média & 0,87 & 0,92 & 0,73 & 0,34 & $15,99 \%$ & $63,36 \%$ \\
Mediana & 0,88 & 0,96 & 0,75 & 0,24 & $6,51 \%$ & $70,21 \%$ \\
Desvio padrão & 0,10 & 0,12 & 0,17 & 0,27 & $18,40 \%$ & $27,08 \%$ \\
Mínimo & 0,68 & 0,71 & 0,47 & 0,08 & $4,12 \%$ & $30,30 \%$ \\
Máximo & 0,97 & 1,03 & 0,93 & 0,69 & $51,04 \%$ & $92,23 \%$ \\
\hline
\end{tabular}


As tabelas $11,12,13,14,15,16$ e 17 demonstram os resultados obtidos a partir da aplicação do teste de Wilcoxon. Para todos os testes, os valores considerados estatisticamente significativos são aqueles em que $p \leq 0,05$, ou seja, a probabilidade de o valor obtido ocorrer ao acaso é menor do que $5 \%$. O valores estatisticamente significativos encontram-se assinalados com um asterisco nas tabelas e serão esclarecidos a seguir.

Considerando-se a densidade óptica radiográfica, os objetivos da avaliação estatística foram verificar se houve diferença entre os valores obtidos no grupo polímero e no grupo controle dentro de um mesmo momento de coleta (Tabela 11); dentro do grupo polímero entre o momento D0 e os demais (Tabela 12); e dentro do grupo controle entre o momento D0 e os demais (Tabela 13).

Dessa forma, visou-se: verificar se a densidade óssea retornaria aos valores originais; identificar o momento em que isso ocorreu; se ocorreu em ambos os grupos e se havia alguma diferença entre os mesmos com relação à temporalidade.

Tabela 11 - Resultados do teste de Wilcoxon entre a densidade radiográfica dos grupos polímero (Pol) e controle (Cont) nos diferentes momentos de coleta - São Paulo - 2011 a 2013

\begin{tabular}{lcccccc}
$\begin{array}{l}\text { Pol D0 x } \\
\text { Cont D0 }\end{array}$ & $\begin{array}{c}\text { Pol D7 x } \\
\text { Cont D7 }\end{array}$ & $\begin{array}{c}\text { Pol D15 x } \\
\text { Cont D15 }\end{array}$ & $\begin{array}{l}\text { Pol D30 x } \\
\text { Cont D30 }\end{array}$ & $\begin{array}{l}\text { Pol D60 x } \\
\text { Cont D60 }\end{array}$ & $\begin{array}{l}\text { Pol D90 x } \\
\text { Cont D90 }\end{array}$ & $\begin{array}{c}\text { Pol D120 x } \\
\text { Cont D120 }\end{array}$ \\
\hline$-0,577$ & $-0,425$ & $-0,68$ & $-1,581$ & $-1,382$ & $-2,220$ & $-2,214$ \\
0,564 & 0,671 & 0,496 & 0,114 & 0,167 & $0,026^{*}$ & $0,027^{*}$ \\
\hline
\end{tabular}

Tabela 12 - Resultados do teste de Wilcoxon da densidade radiográfica do grupo polímero (Pol) entre D0 e os demais momentos de coleta - São Paulo - 2011 a 2013

\begin{tabular}{ccccccc} 
& $\begin{array}{c}\text { Pol D0 } x \\
\text { Pol D7 }\end{array}$ & $\begin{array}{c}\text { Pol D0 x } \\
\text { Pol D15 }\end{array}$ & $\begin{array}{c}\text { Pol D0 } x \\
\text { Pol D30 }\end{array}$ & $\begin{array}{c}\text { Pol D0 } x \\
\text { Pol D60 }\end{array}$ & $\begin{array}{c}\text { Pol D0 } x \\
\text { Pol D90 }\end{array}$ & $\begin{array}{c}\text { Pol D0 } x \\
\text { Pol D120 }\end{array}$ \\
\hline$z$ & $-2,214$ & $-2,264$ & $-2,214$ & $-2,264$ & $-2,214$ & $-2,214$ \\
$p$ & $0,027^{*}$ & $0,024^{*}$ & $0,027^{*}$ & $0,024^{*}$ & $0,027^{*}$ & $0,027^{*}$ \\
\hline
\end{tabular}

Tabela 13 - Resultados do teste de Wilcoxon da densidade radiográfica do grupo controle (Cont) entre D0 e os demais momentos de coleta - São Paulo - 2011 a 2013

\begin{tabular}{ccccccc} 
& $\begin{array}{c}\text { Cont D0 x } \\
\text { Cont D7 }\end{array}$ & $\begin{array}{c}\text { Cont D0 x } \\
\text { Cont D15 }\end{array}$ & $\begin{array}{c}\text { Cont D0 x } \\
\text { Cont D30 }\end{array}$ & $\begin{array}{c}\text { Cont D0 x } \\
\text { Cont D60 }\end{array}$ & $\begin{array}{c}\text { Cont D0 x } \\
\text { Cont D90 }\end{array}$ & $\begin{array}{c}\text { Cont D0 x } \\
\text { Cont D120 }\end{array}$ \\
\hline z & $-2,214$ & $-2,226$ & $-2,070$ & $-2,032$ & $-1,841$ & $-1,732$ \\
$\mathrm{p}$ & $0,027^{*}$ & $0,026^{*}$ & $0,038^{*}$ & $0,042^{*}$ & 0,066 & 0,083 \\
\hline
\end{tabular}


Diante dos resultados observados acima, é possível afirmar que a densidade óptica radiográfica não difere entre o grupo preenchido com polímero e o grupo controle até os 90 dias de pós-operatório. Além disso, observou-se que no grupo polímero a densidade, em nenhum dos momentos, tende a se igualar aos valores iniciais (D0); ao contrário do que é observado no grupo controle a partir do D90.

Levando em consideração as variáveis diâmetro transversal, diâmetro longitudinal, área e profundidade das falhas ósseas, os objetivos dos testes estatísticos foram comparar as medidas do grupo controle com as do grupo polímero nos mesmos momentos de coleta; comparar as medidas dentro dos grupos, mas em diferentes momentos de coleta; e comparar a porcentagem de diminuição das medidas entre os dois grupos.

De maneira simplificada, buscou-se avaliar se houve o preenchimento significativo das falhas ósseas dentro de cada grupo, e se a velocidade de preenchimento foi diferente entre os grupos.

Tabela 14 - Resultados do teste de Wilcoxon do diâmetro transversal (D Trans) entre o grupo polímero (Pol) e o grupo controle (Cont) para os mesmos momentos de coleta, dentro de cada grupo para os diferentes momentos de coleta (D7 e D0) e entre a porcentagem de diminuição do diâmetro (\% Dim) de cada grupo - São Paulo - 2011 a 2013

D Trans Pol D7 x D Trans Pol D120 x D Trans Pol D7 x D Trans Cont D7 x \% Dim Pol x

D Trans Cont D7 D Trans Cont D120 D Trans Pol D120 D Trans Cont D120 \% Dim Cont

\begin{tabular}{llllll}
\hline$z$ & $-0,406$ & $-2,201$ & $-2,023$ & $-2,201$ & $-2,201$ \\
$p$ & 0,684 & $0,028^{*}$ & $0,043^{*}$ & $0,028^{*}$ & $0,028^{*}$ \\
\hline
\end{tabular}

Tabela 15 - Resultados do teste de Wilcoxon do diâmetro longitudinal (D Long) entre o grupo polímero (Pol) e o grupo controle (Cont) para os mesmos momentos de coleta, dentro de cada grupo para os diferentes momentos de coleta (D7 e D0) e entre a porcentagem de diminuição do diâmentro (\% Dim) de cada grupo - São Paulo - 2011 a 2013

D Long Pol D7 x D Long Pol D120 x D Long Pol D7 x D Long Cont D7 x \% Dim Pol x

D Long Cont D7 D Long Cont D120 D Long Pol D120 D Long Cont D120 \% Dim Cont

\begin{tabular}{llllll}
\hline$z$ & $-1,265$ & $-2,201$ & $-2,023$ & $-2,201$ & $-2,201$ \\
$p$ & 0,206 & $0,028^{*}$ & $0,043^{*}$ & $0,028^{*}$ & $0,028^{*}$ \\
\hline
\end{tabular}


Tabela 16 - Resultados do teste de Wilcoxon da área entre o grupo polímero (Pol) e o grupo controle (Cont) para os mesmos momentos de coleta, dentro de cada grupo para os diferentes momentos de coleta (D7 e D0) e entre a porcentagem de diminuição da área (\% Dim) de cada grupo - São Paulo - 2011 a 2013

\begin{tabular}{cccccc}
\hline & $\begin{array}{c}\text { Área Pol D7 x } \\
\text { Área Cont D7 }\end{array}$ & $\begin{array}{c}\text { Área Pol D120 x } \\
\text { Área Cont D120 }\end{array}$ & $\begin{array}{c}\text { Área Pol D7 x } \\
\text { Área Pol D120 }\end{array}$ & $\begin{array}{c}\text { Área Cont D7 x } \\
\text { Área Cont D120 }\end{array}$ & $\begin{array}{c}\text { \% Dim Pol x } \\
\% \text { Dim Cont }\end{array}$ \\
\hline $\mathrm{z}$ & $-0,944$ & $-2,201$ & $-2,023$ & $-2,201$ & $-2,201$ \\
$\mathrm{p}$ & 0,345 & $0,028^{*}$ & $0,043^{*}$ & $0,028^{*}$ & $0,028^{*}$ \\
\hline
\end{tabular}

Tabela 17 - Resultados do teste de Wilcoxon da profundidade (Prof) entre o grupo polímero (Pol) e o grupo controle (Cont) para os mesmos momentos de coleta, dentro de cada grupo para os diferentes momentos de coleta (D7 e D0) e entre a porcentagem de diminuição da profundidade (\% Dim) de cada grupo - São Paulo - 2011 a 2013

\begin{tabular}{cccccc}
\hline & $\begin{array}{c}\text { Prof Pol D7 x } \\
\text { Prof Cont D7 }\end{array}$ & $\begin{array}{c}\text { Prof Pol D120 x } \\
\text { Prof Cont D120 }\end{array}$ & $\begin{array}{c}\text { Prof Pol D7 x } \\
\text { Prof Pol D120 }\end{array}$ & $\begin{array}{c}\text { Prof Cont D7 x } \\
\text { Prof Cont D120 }\end{array}$ & $\begin{array}{c}\text { \% Dim Pol x } \\
\% \text { Dim Cont }\end{array}$ \\
\hline$z$ & $-1,219$ & $-2,201$ & $-2,226$ & $-2,207$ & $-2,201$ \\
$\mathrm{p}$ & 0,223 & $0,028^{*}$ & $0,026^{*}$ & $0,027^{*}$ & $0,028^{*}$ \\
\hline
\end{tabular}

Diante dos resultados observados nas tabelas 14, 15, 16 e 17 é possível afirmar que há diferença estatística entre todas as medidas quando se compara o grupo controle com o grupo polímero 120 dias após a indução das falhas ósseas, assim como quando se compara a porcentagem de diminuição das medidas. mesmo não foi observado no momento $D 7$, possivelmente porque este era imediato à confecção das falhas e muito precoce para a avaliação de preenchimento das mesmas. Além disso, a alteração de todas as medidas desde o momento D7 até o D120 foi estatisticamente significativa dentro de cada um dos grupos.

Portanto, houve preenchimento significativo das falhas ósseas tanto na presença como na ausência do biomaterial. No entanto, este processo ocorre em velocidades diferentes em cada grupo, sendo mais lento naquele que foi preenchido com o polímero.

Considerando a análise qualitativa das imagens, não foram observados indícios de deslocamento dos implantes, tampouco de osteólise ou de reações ósseas proliferativas exuberantes adjascentes às falhas. 


\subsection{AVALIAÇÃO POR MOL}

As tabelas 18 e 19 apresentam os resultados obtidos a partir da quantificação realizada durante a análise por MOL nos grupos polímero e controle, respectivamente. Podem ser observados o número total de campos avaliados em cada grupo, as áreas total e de osso neoformado de cada campo (em $\left.\mu^{2}\right)$, a relação entre estas duas mensurações, a média das porcentagens de osso neoformado e seu respectivo desvio padrão.

Diferentemente das demais avaliações, não foi possível analisar o material de cada indivíduo e compará-los entre si devido à algumas lâminas não se apresentarem adequadas à análise. Dessa forma, tal material foi excluído da avaliação e as lâminas restantes foram agrupadas nas categorias polímero e controle, sendo submetidas ao sistema de quantificação por campos. É por esta razão que o número de campos avaliados difere entre os grupos. 
Tabela 18 - Área total e de osso neoformado (Neo) nos cortes histológicos de fragmentos de biópsia óssea com preenchimento pelo biomaterial. Também é apresentada a proporção entre a área de osso neoformado e a área total de tecido - São Paulo - 2011 a 2013

\begin{tabular}{|c|c|c|c|c|}
\hline Grupo & Campo & Área Total $\left(\mu \mathrm{m}^{2}\right)$ & Área Neoformada $\left(\mu \mathrm{m}^{2}\right)$ & \% Área Neoformada \\
\hline \multirow{29}{*}{ 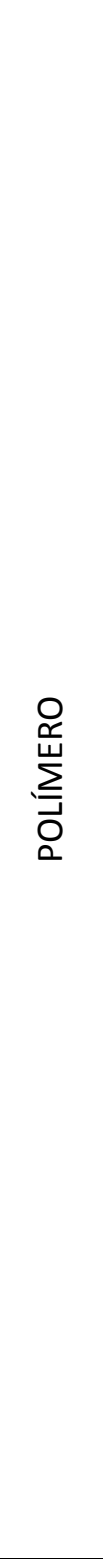 } & 1 & 113064 & 47728 & 42,21 \\
\hline & 2 & 126160 & 28298 & 22,43 \\
\hline & 3 & 112002 & 18189 & 16,24 \\
\hline & 4 & 109832 & 30495 & 27,77 \\
\hline & 5 & 117143 & 72551 & 61,93 \\
\hline & 6 & 115191 & 30733 & 26,68 \\
\hline & 7 & 119616 & 47809 & 39,97 \\
\hline & 8 & 114572 & 36619 & 31,96 \\
\hline & 9 & 111240 & 21855 & 19,65 \\
\hline & 10 & 113432 & 7070 & 6,23 \\
\hline & 11 & 116986 & 31354 & 26,80 \\
\hline & 12 & 123217 & 33656 & 27,31 \\
\hline & 13 & 106212 & 21799 & 20,52 \\
\hline & 14 & 124485 & 12890 & 10,35 \\
\hline & 15 & 122828 & 56401 & 45,92 \\
\hline & 16 & 122974 & 41460 & 33,71 \\
\hline & 17 & 118633 & 25663 & 21,63 \\
\hline & 18 & 124429 & 45196 & 36,32 \\
\hline & 19 & 124729 & 55911 & 44,83 \\
\hline & 20 & 122366 & 30222 & 24,70 \\
\hline & 21 & 122093 & 28631 & 23,45 \\
\hline & 22 & 67405 & 20612 & 30,58 \\
\hline & 23 & 115783 & 17055 & 14,73 \\
\hline & 24 & 116584 & 26266 & 22,53 \\
\hline & 25 & 108220 & 11492 & 10,62 \\
\hline & 26 & 711460 & 208100 & 29,25 \\
\hline & 27 & 92870 & 22362 & 24,08 \\
\hline & 28 & 103988 & 25380 & 24,41 \\
\hline & 29 & 114782 & 16605 & 14,47 \\
\hline & & & Média & 26,94 \\
\hline & & & Desvio Padrão & 12,06 \\
\hline
\end{tabular}


Tabela 19 - Área total e de osso neoformado nos cortes histológicos de fragmentos de biópsia óssea sem preenchimento com biomaterial. Também é apresentada a proporção entre a área de osso neoformado e a área total de tecido - São Paulo - 2011 a 2013

\begin{tabular}{|c|c|c|c|c|}
\hline Grupo & Campo & Área Total $\left(\mu \mathrm{m}^{2}\right)$ & Área Neoformada $\left(\mu \mathrm{m}^{2}\right)$ & \% Área Neoformada \\
\hline \multirow{26}{*}{ 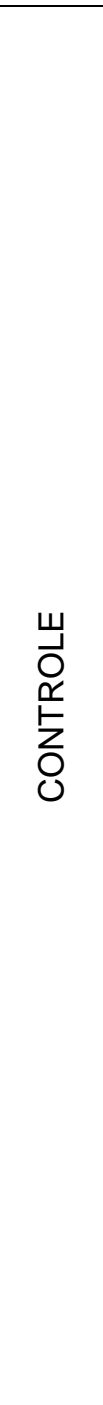 } & 1 & 4333730 & 2771690 & 63,96 \\
\hline & 2 & 5520740 & 2982060 & 54,02 \\
\hline & 3 & 4849790 & 3158130 & 65,12 \\
\hline & 4 & 569070 & 315923 & 55,52 \\
\hline & 5 & 569070 & 323324 & 56,82 \\
\hline & 6 & 4850430 & 2323890 & 47,91 \\
\hline & 7 & 5033330 & 2929290 & 58,20 \\
\hline & 8 & 5469080 & 3998030 & 73,10 \\
\hline & 9 & 5467840 & 2904960 & 53,13 \\
\hline & 10 & 5408270 & 1366020 & 25,26 \\
\hline & 11 & 5041640 & 1774340 & 35,19 \\
\hline & 12 & 569070 & 145186 & 25,51 \\
\hline & 13 & 5189210 & 1592900 & 30,70 \\
\hline & 14 & 506410 & 134780 & 26,61 \\
\hline & 15 & 460110 & 99642 & 21,66 \\
\hline & 16 & 569070 & 345104 & 60,64 \\
\hline & 17 & 569070 & 219406 & 38,56 \\
\hline & 18 & 569070 & 252782 & 44,42 \\
\hline & 19 & 5302950 & 3719750 & 70,14 \\
\hline & 20 & 5455630 & 3723460 & 68,25 \\
\hline & 21 & 5568610 & 3158020 & 56,71 \\
\hline & 22 & 569070 & 293020 & 51,49 \\
\hline & 23 & 569070 & 293759 & 51,62 \\
\hline & 24 & 5124020 & 3068730 & 59,89 \\
\hline & 25 & 5408460 & 3066140 & 56,69 \\
\hline & 26 & 5060130 & 2672290 & 52,81 \\
\hline & & & Média & 50,15 \\
\hline & & & Desvio Padrão & 14,83 \\
\hline
\end{tabular}

A comparação direta entre a média da porcentagem de osso neoformado do grupo polímero com o controle revela que ocorreu maior formação de tecido ósseo na ausência do biomaterial. No entanto, os resultados foram comparados estatisticamente através do teste de Wilcoxon, também executado no programa IBM 
SPSS Statistics V.18.0 ${ }^{\circledR}$, sob as mesmas condições descritas anteriormente, para a validação dos resultados.

Nas tabelas 20 e 21 são apresentados os descritores da variável porcentagem de osso neoformado dos grupos avaliados e os resultados do teste de Wilcoxon, respectivamente.

Tabela 20 - Descritores da variável \%Osso Neoformado (Neo) nos grupos polímero (Pol) e controle (Cont) - São Paulo - 2011 a 2013

\begin{tabular}{lcc}
\hline \multicolumn{1}{c}{ Descritor } & \%Osso Neo Pol & \%Osso Neo Cont \\
\hline $\mathrm{N}$ & 29 & 29 \\
Média & 26,94 & 50,15 \\
Mediana & 24,00 & 53,50 \\
Desvio padrão & 12,06 & 14,83 \\
Minimo & 6,00 & 21.00 \\
Máximo & 61,00 & 73.00 \\
\hline
\end{tabular}

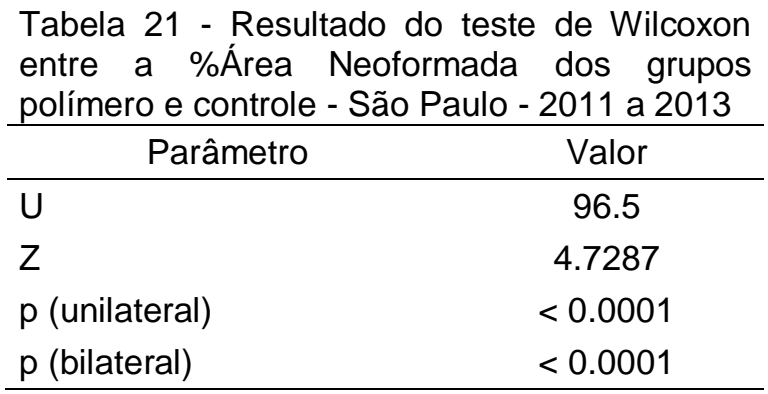

De acordo com os valores de $p$ obtidos $(<0,0001)$, é possível afirmar que a quantidade de tecido ósseo neoformado difere significativamente entre os grupo, sendo evidentemente menor no grupo polímero.

Embora o objetivo principal da avaliação por MOL tenha sido a avaliação quantitativa, os cortes histológicos obtidos também foram analisados qualitativamente quanto à sua morfologia. A observação dos fragmentos obtidos no ato da indução das falhas ósseas permitiu registrar o padrão organizacional do tecido ósseo compacto maduro na espécie equina (figura 23), e obter parâmetros para comparar os grupos polímero e controle.

A análise dos fragmentos de biópsia do grupo controle evidenciou a formação de tecido ósseo novo devido à presença de matriz desorganizada em interface com tecido ósseo maduro, caracterizado pela presença de ósteons (figura 24). O mesmo também pôde ser observado no caso das biópsias do grupo polímero (figura 25); no 
entanto, a quantidade de tecido ósseo neoformado foi bem menor, e esta situava-se entre o tecido ósseo pré-existente e o biomaterial.

Além disso, não foi possível observar a formação de tecido fibroso ao redor do polímero, nem de reações semelhantes à de corpo estranho. O aspecto do tecido neoformado na presença do polímero foi o mesmo daquele encontrado na reparação óssea fisiológica (grupo controle).

Figura 23 - Fragmento ósseo coletado durante a confecção da falha óssea

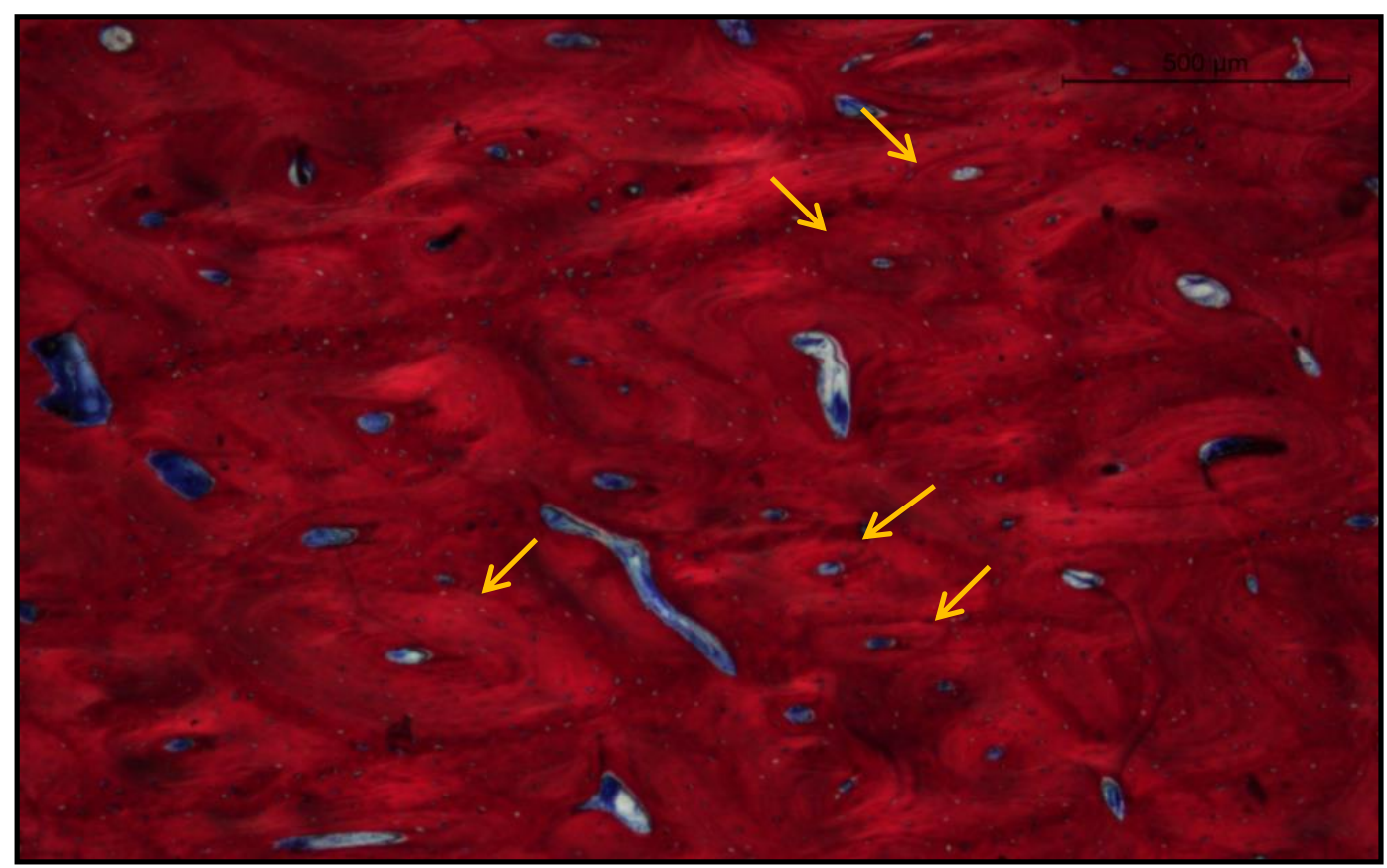

Observação de tecido ósseo compacto maduro (padrão lamelar). Setas amarelas apontam diversas lamelas concêntricas.Coloração Stevenel's Blue, aumento original de $50 x$.

Fonte: Selim, M. B. (2013) 
Figura 24 - Fragmento ósseo de biópsia do grupo controle

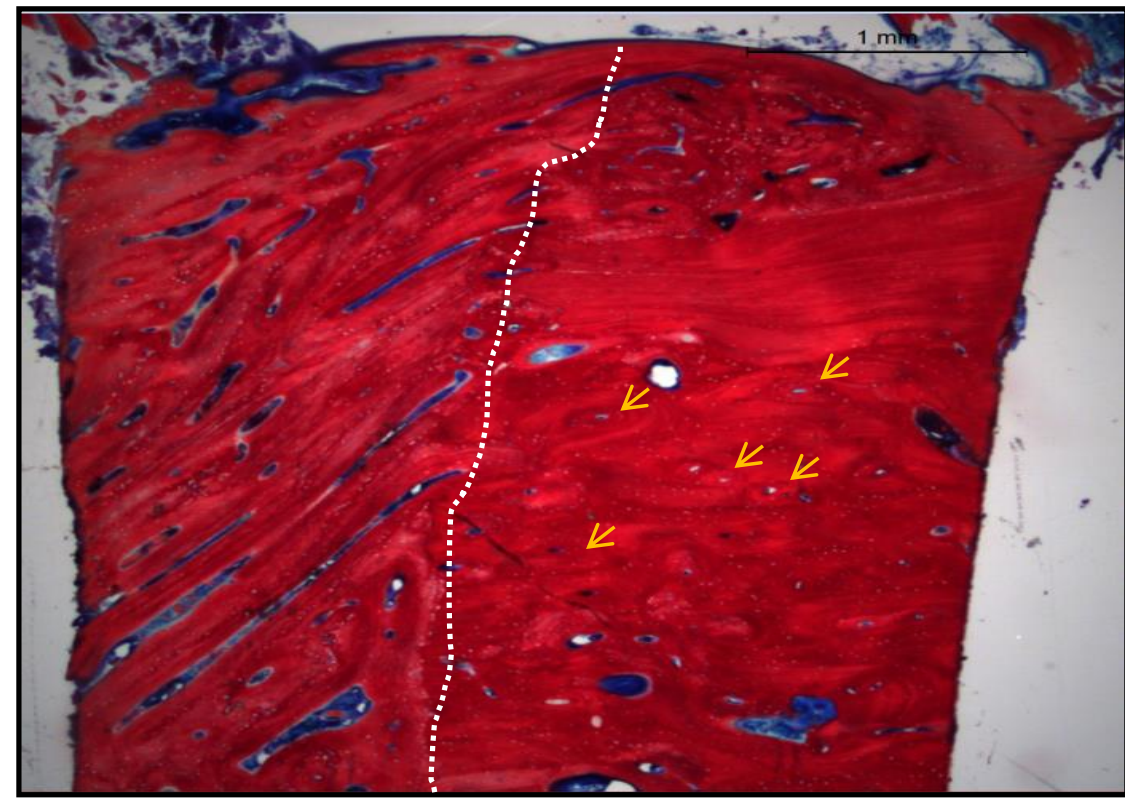

Observação de tecido neoformado (à esquerda da pontilhada branca) em interface com tecido ósseo maduro pré-existente (à direita da linha pontilhada branca), organizado em padrão lamelar (lamelas apontadas pelas setas amarelas). Coloração Stevenel's Blue, aumento original de $25 \mathrm{x}$.

Fonte: Selim, M. B. (2013)

Figura 25 - Fragmento ósseo de biópsia do grupo polímero

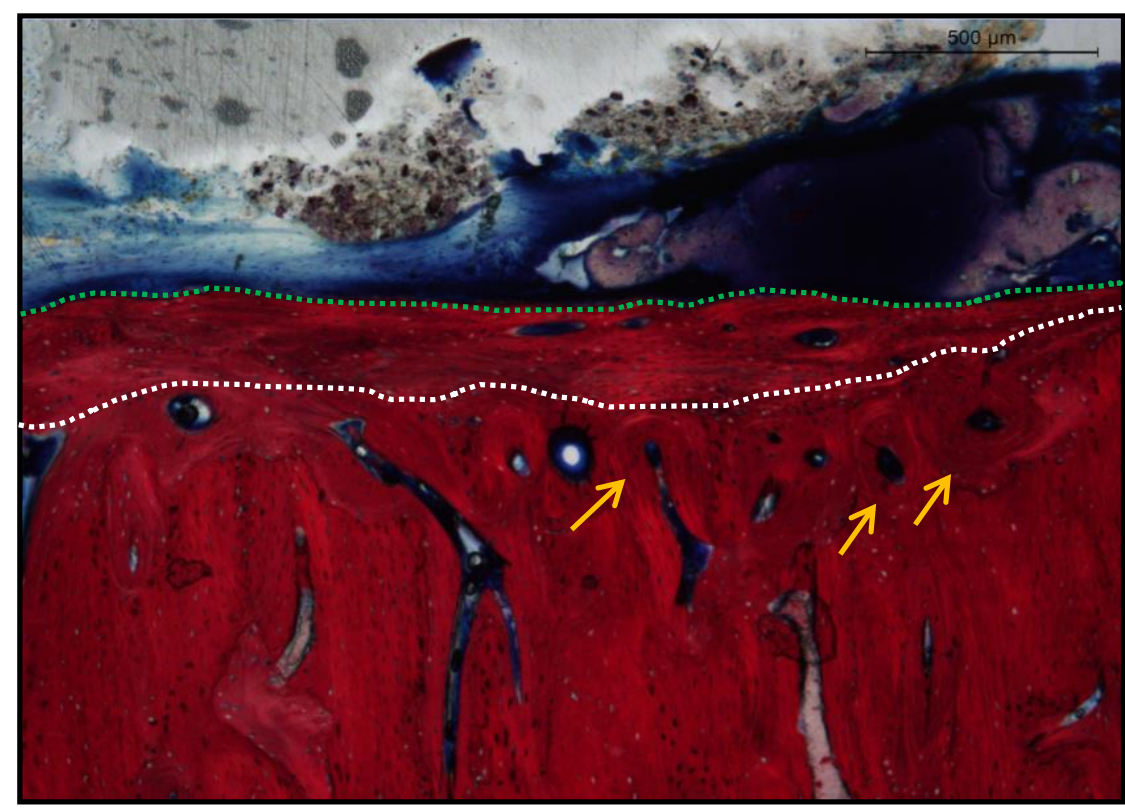

Observação de faixa de tecido ósseo neoformado (entre as linhas pontilhadas verde e branca) entre tecido ósseo pré existente (abaixo da linha pontilhada branca) e polímero (material acima da linha pontilhada verde). As setas amarelas indicam as lamelas concêntricas do tecido ósseo maduro. Coloração Stevenel's Blue, aumento original de 50x.

Fonte: Selim, M. B. (2013) 
Em alguns cortes foram observadas imagens sugestivas da invasão da matriz polimérica por tecido ósseo novo (figura 26); e também de algumas áreas em meio ao tecido neoformado que se assemelhavam ao biomaterial em possível processo de degradação . Não foram encontrados sinais da formação de cartilagem, indicando a ocorrência de reparação através de ossificação intramembranosa.

Figura 26 - Fragmento ósseo de biópsia do grupo polímero

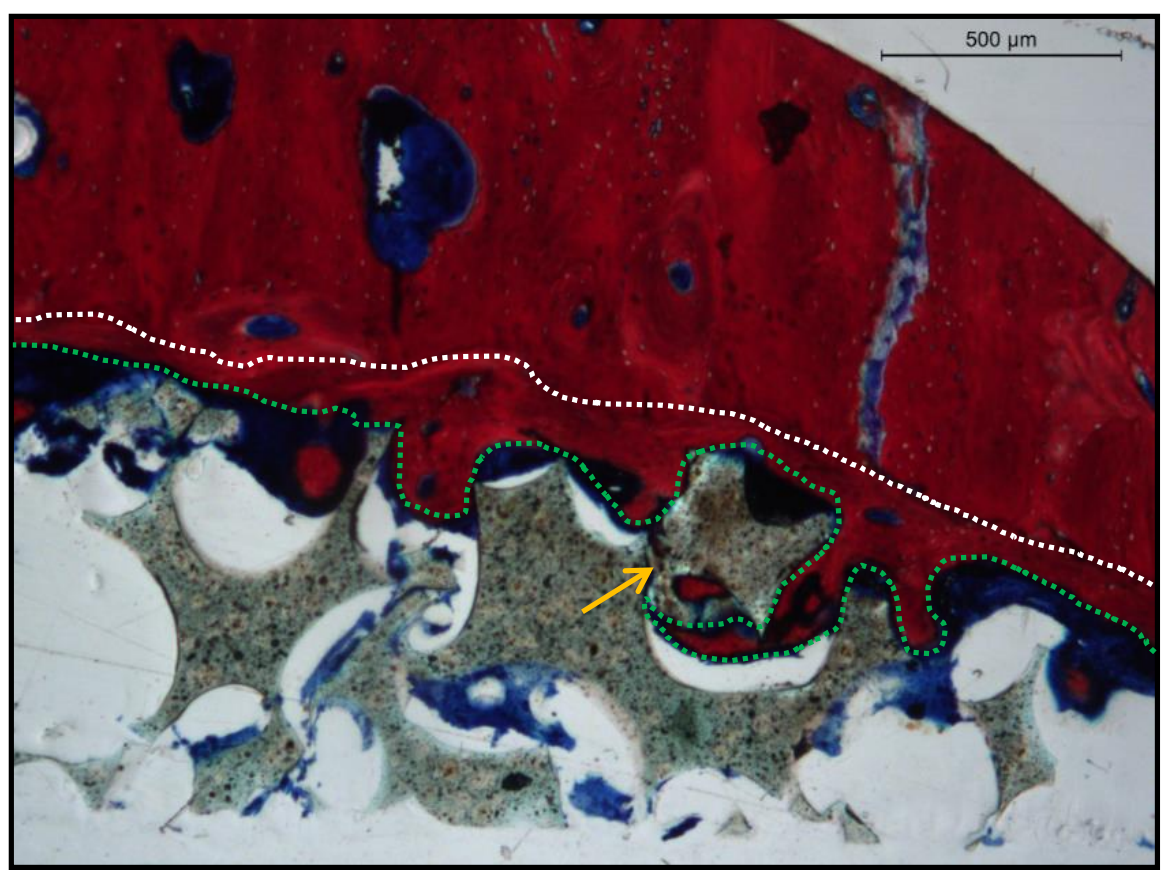

Observação Tecido ósseo novo (entre as linhas pontilhadas verde e branca) localizado entre biomaterial (abaixo da linha pontilhada verde) e tecido ósseo maduro (acima da linha pontilhada branca). Notar as projeções de tecido ósseo neoformado em direção ao biomaterial. A seta vermelha aponta uma área que sugere o englobamento de parte do biomaterial pelo tecido ósseo em crescimento. Coloração Stevenel's Blue, aumento original de 50x.

Fonte: Selim, M. B. (2013)

Portanto, o biomaterial estudado apresentou comportamento osteocondutor discreto e biocompatibilidade com o tecido ósseo equino, não desencadeando reações adversas tais como a modificação da arquitetura tecidual original. 


\subsection{AVALIAÇÃO POR MEV}

Inicialmente foram analisados os fragmentos ósseos coletados durante a confecção das falhas para registrar o padrão estrutural do tecido ósseo equino. $A$ partir desta análise observou-se o padrão característico de tecido ósseo compacto, tanto nas suas formas madura e imatura (figuras 27 e 28). $O$ osso maduro ou secundário apresenta grande quantidade de matriz mineralizada e organizada regularmente, pequena quantidade de lacunas de osteócitos e a presença de canais de Havers. No entanto, o osso imaturo possuiu matriz formada predominantemente por colágeno, com baixo grau de mineralização e organização, não permitindo a observação de canais de Havers, mas somente de lacunas de osteócitos. 
Figura 27 - Fragmentos ósseos coletados durante a confecção das falhas ósseas

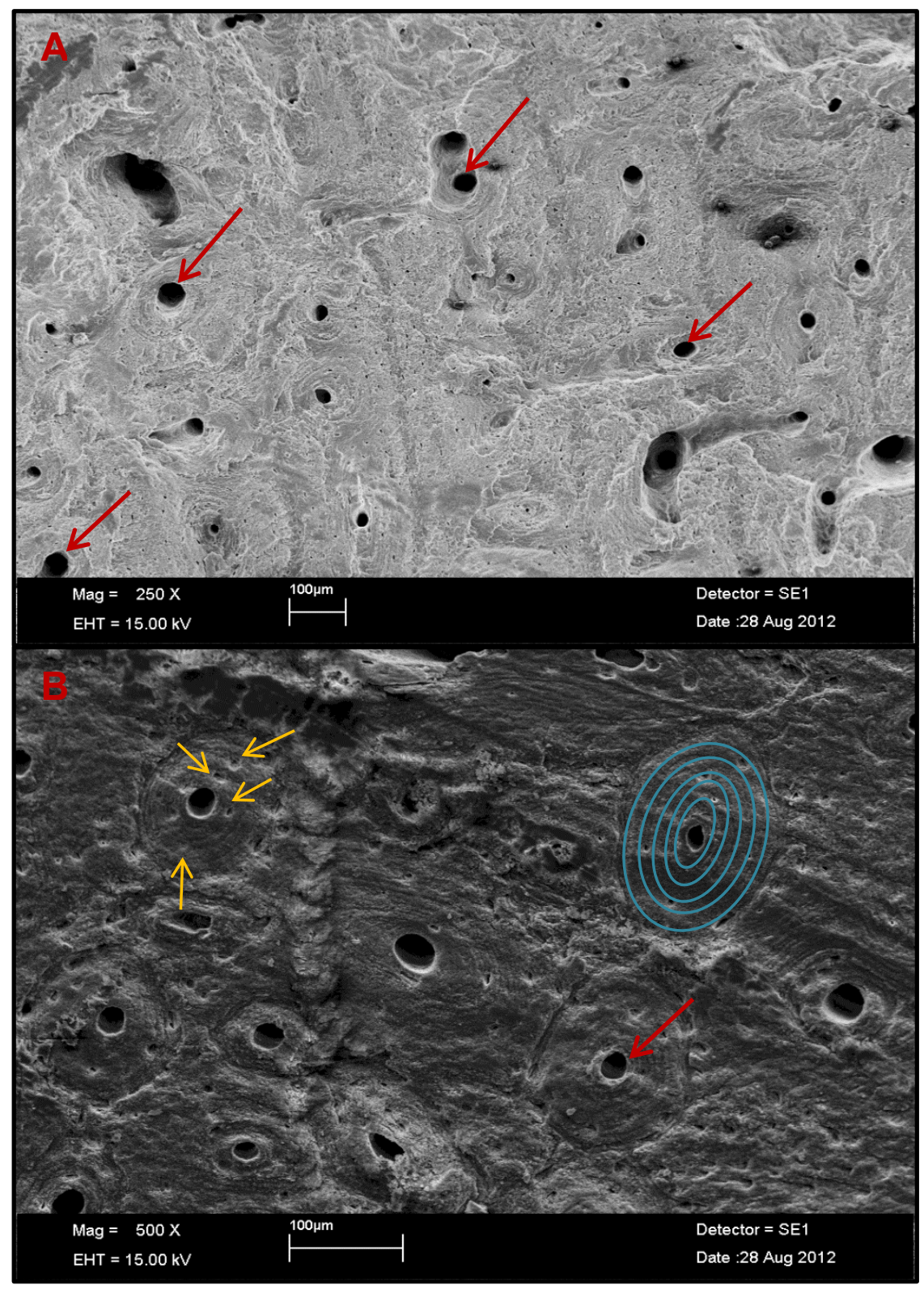

A - Tecido ósseo compacto maduro, com a presença de canais de Havers (setas vermelhas). B - Maior aumento da imagem A. Observação de canal de Havers (seta vermelha), lacunas de osteócitos (setas amarelas) e matriz óssea organizada em lamelas concêntricas (elipses azuis).

Fonte: Selim, M. B. (2013) 
Figura 28 - Fragmentos ósseos coletados durante a confecção das falhas ósseas

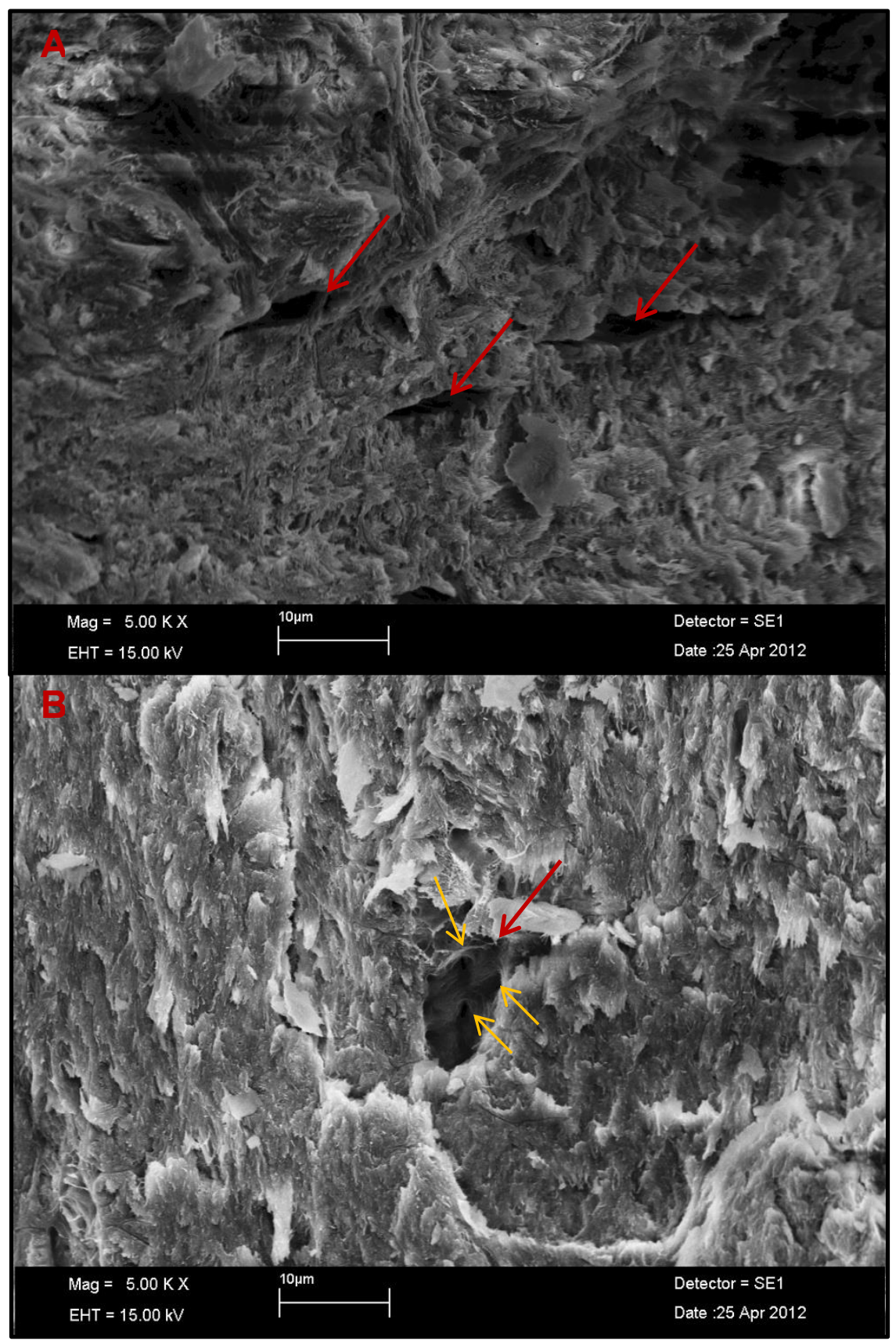

A - Tecido ósseo compacto imaturo, com a presença de lacunas de osteócitos (setas vermelhas) em meio à matriz óssea pouco organizada. B - Tecido ósseo compacto imaturo com lacuna de osteócito em evidência (seta vermelha), com detalhe para os seus poros, pelos quais passam os prolongamentos do osteócito. Matriz desorganizada ao redor.

Fonte: Selim, M. B. (2013) 
Também foi observado ao MEV um fragmento de polímero para descrever suas características morfológicas originais e compará-las posteriormente após o contato com o tecido ósseo dos animais (figura 29). Trata-se de um material bastante poroso, onde são observadas diversas lacunas circulares separadas umas das outras por finas trabéculas de material com aspecto heterogêneo, o qual assemelha-se bastante ao osso compacto imaturo (figura 30 ).

Figura 29 - Fragmentos do polímero de poliuretana de mamona antes da implantação no tecido ósseo equino

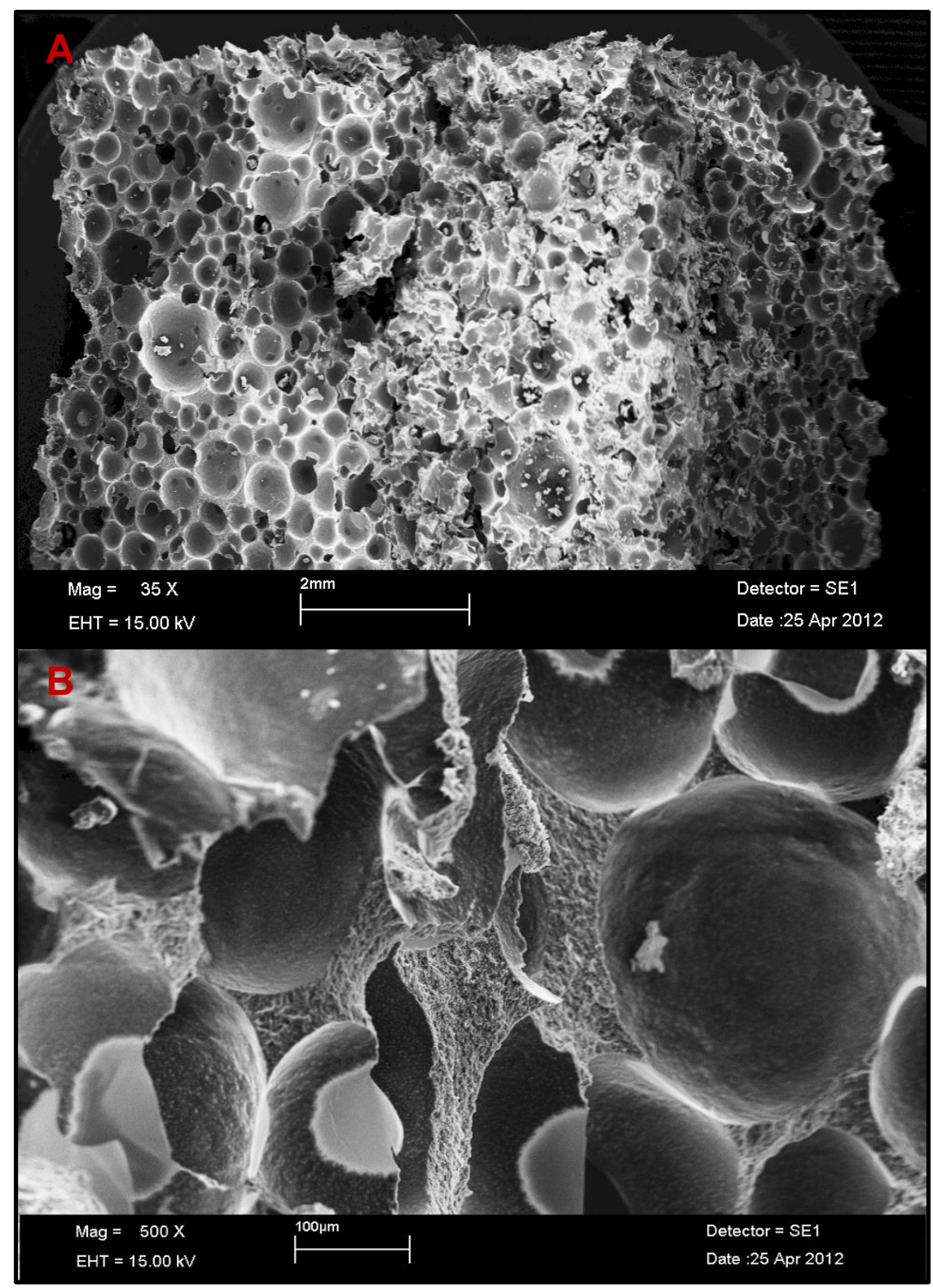

A - Material poroso formado por inúmeras cavidades circulares delimitadas por finas trabéculas de material heterogêneo. B - Aspecto do polímero numa visão mais próxima, evidenciando a estrutura de suas trabéculas.

Fonte: Selim. M. B. (2013) 
Figura 30 Comparação entre a estrutura do biomaterial e à do tecido ósseo imaturo equino.

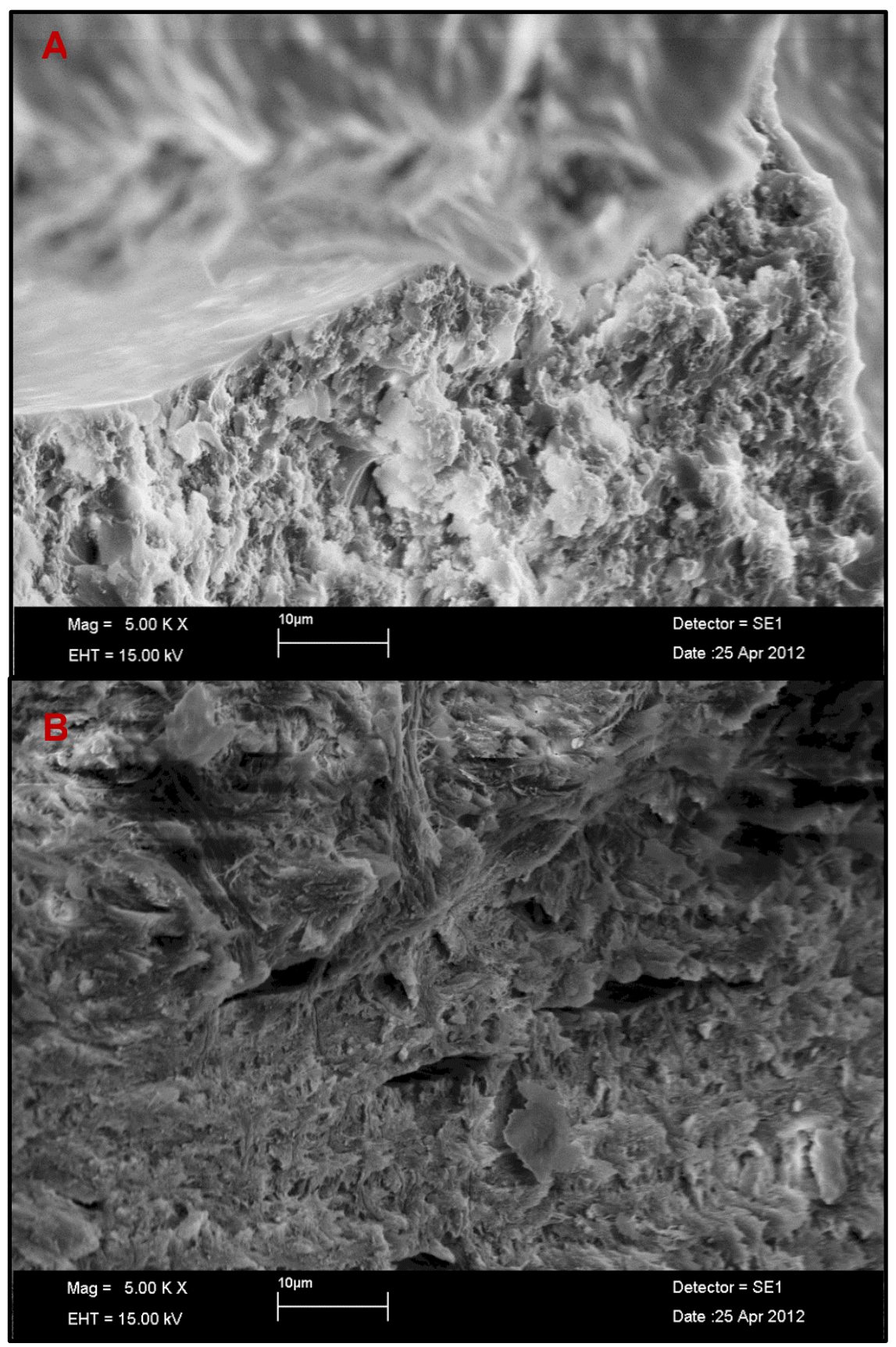

A - Imagem muito próxima de uma trabécula polimérica. B - Tecido ósseo equino imaturo observado com a mesma magnificação da imagem A. Detalhe para a grande similaridade estrutural entre os dois materiais.

Fonte: Selim, M. B. (2013)

Ao vizualizar os fragmentos de biópsia provenientes das falhas sem preenchimento com o polímero, constatou-se a presença de regiões de osso neoformado em interface com regiões de osso pré existente, em proporções de área 
semelhantes (figura 31). O osso formado nestes casos apresentava aspecto similar ao do osso imaturo observado nos fragmentos de controle.

Figura 31 - Fragmento ósseo coletado durante a biópsia de falha não preenchida com biomaterial

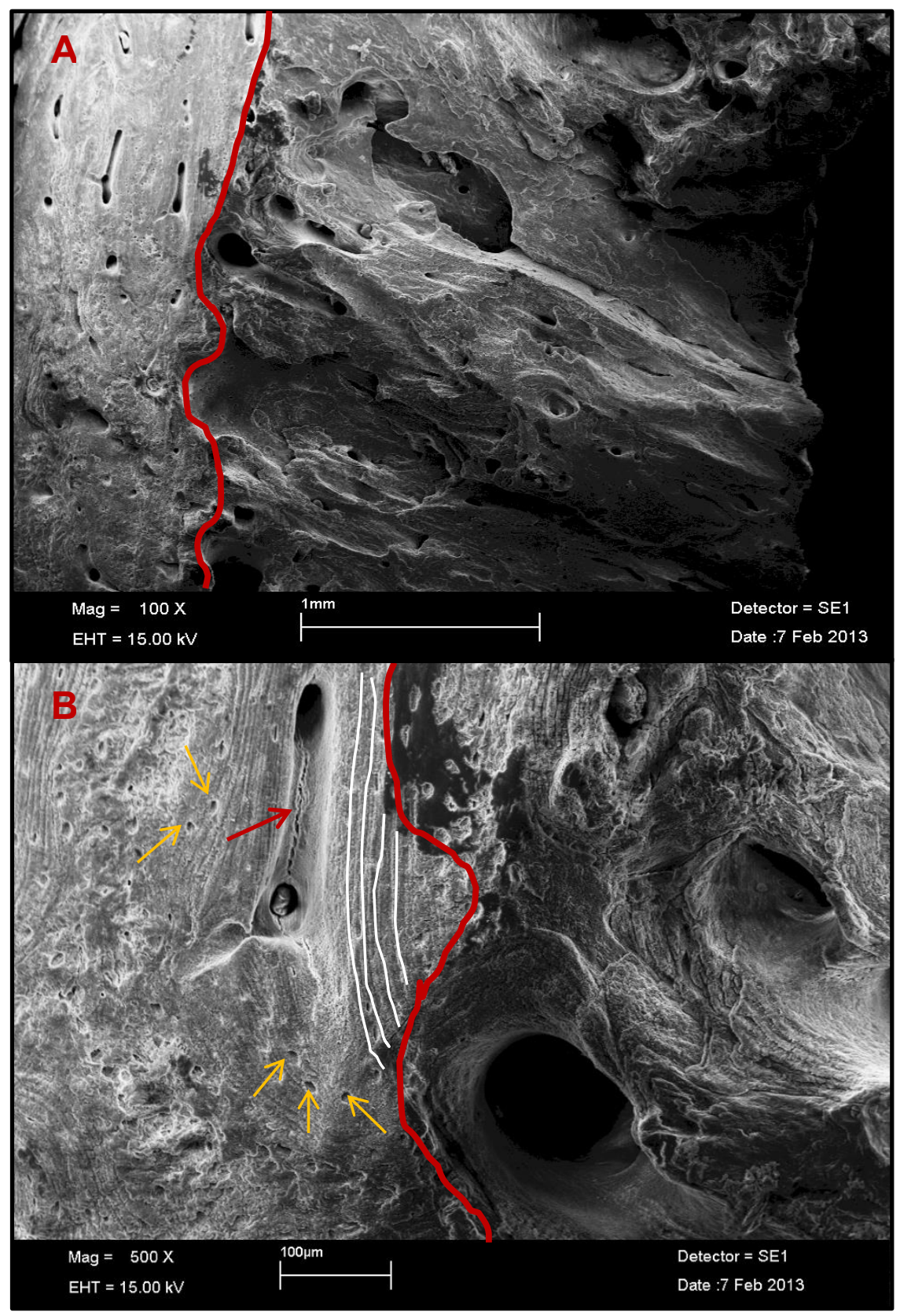

A - Tecido ósseo pré existente à esquerda da linha vermelha e tecido ósseo neoformado à direita. B - Magnificação da imagem anterior. À esquerda da linha vermelha observa-se tecido ósseo secundário com a presença de canal de Havers em corte longitudinal (seta vermelha), lacunas de osteócitos (setas amarelas) e lamelas de matriz óssea paralelas ao canal de Havers (linhas brancas). À direita da linha vermelha observa-se tecido ósseo primário, com matriz predominantemente colágena e pouco organizada.

Fonte: Selim, M. B. (2013) 
A análise dos fragmentos de biópsia das falhas preenchidas com o polímero revelou a formação de faixas pouco significativas (figura 32) ou pequenas áreas isoladas de tecido ósseo novo (figura 33), as quais se situavam entre grandes áreas de tecido ósseo pré existente e de material polimérico. Em apenas um animal não foi possível observar estas áreas de osso neoformado (figura 34).

Apesar de pequenas, as áreas de osso neorfomado apresentaram o mesmo aspecto estrutural observado nos fragmentos de biópsia das falhas não preenchidas (figura 35).

O aspecto do polímero após a implantação assemelha-se bastante à sua configuração original, apresentando discretos sinais de deterioração e fragmentação, e ausência aparente de deposição de tecido ósseo sobre o mesmo ou invadindo-o internamente (figura 33).

Figura 32 - Fragmento ósseo coletado durante biópsia de falha preenchida com biomaterial

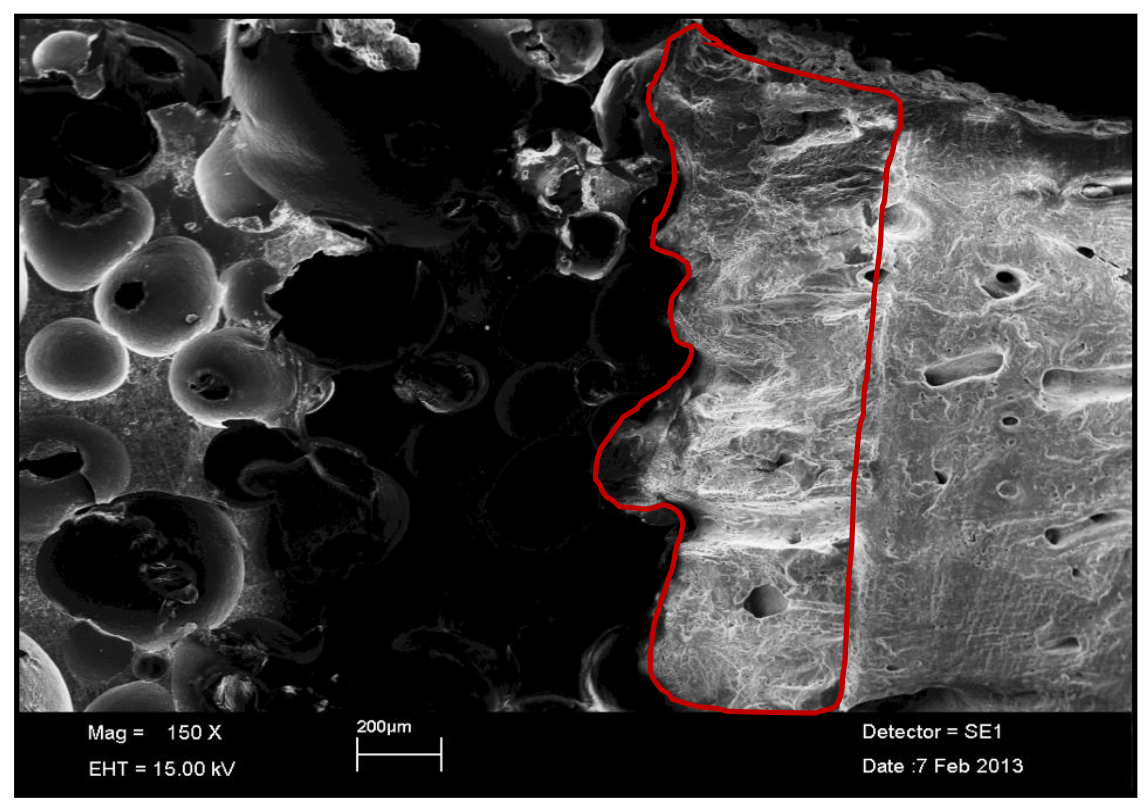

Faixa de tecido ósseo neoformado delimitada pela linha vermelha. Notar que ela se encontra em interface com o biomaterial (à esquerda) e uma área de tecido ósseo pré existente (à direita).

Fonte: Selim, M. B. (2013) 
Figura 33 - Fragmento ósseo coletado durante biópsia de falha preenchida com biomaterial

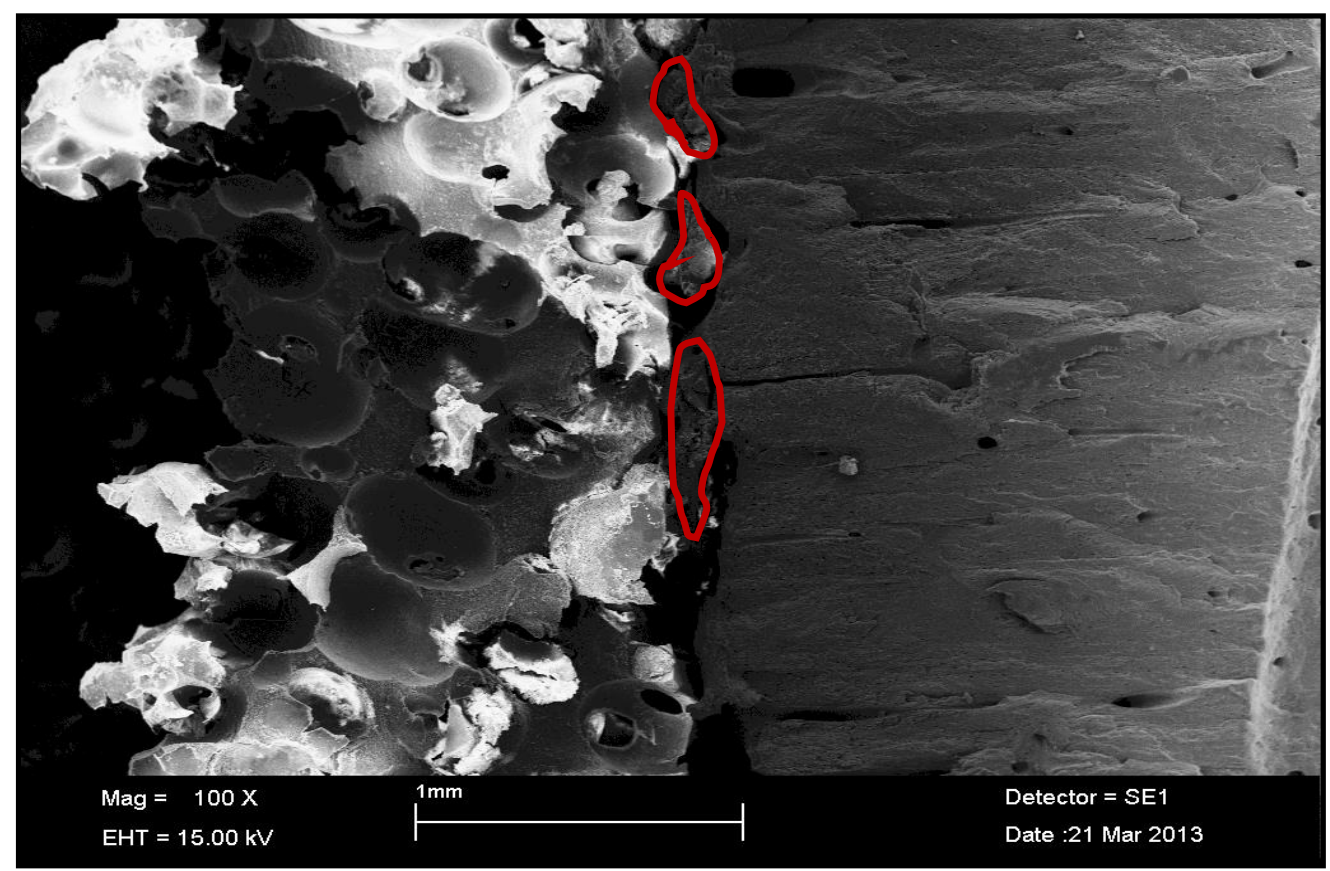

Pequenas áreas de osso neoformado circundadas em vermelho, situadas entre o biomaterial (à esquerda) e tecido ósseo compacto pré existente (à direita). Observa-se a integridade relativa do biomaterial, com pequenos pontos de deterioração.

Fonte: Selim, M. B. (2013)

Figura 34 - Fragmento ósseo coletado durante biópsia de falha preenchida com biomaterial

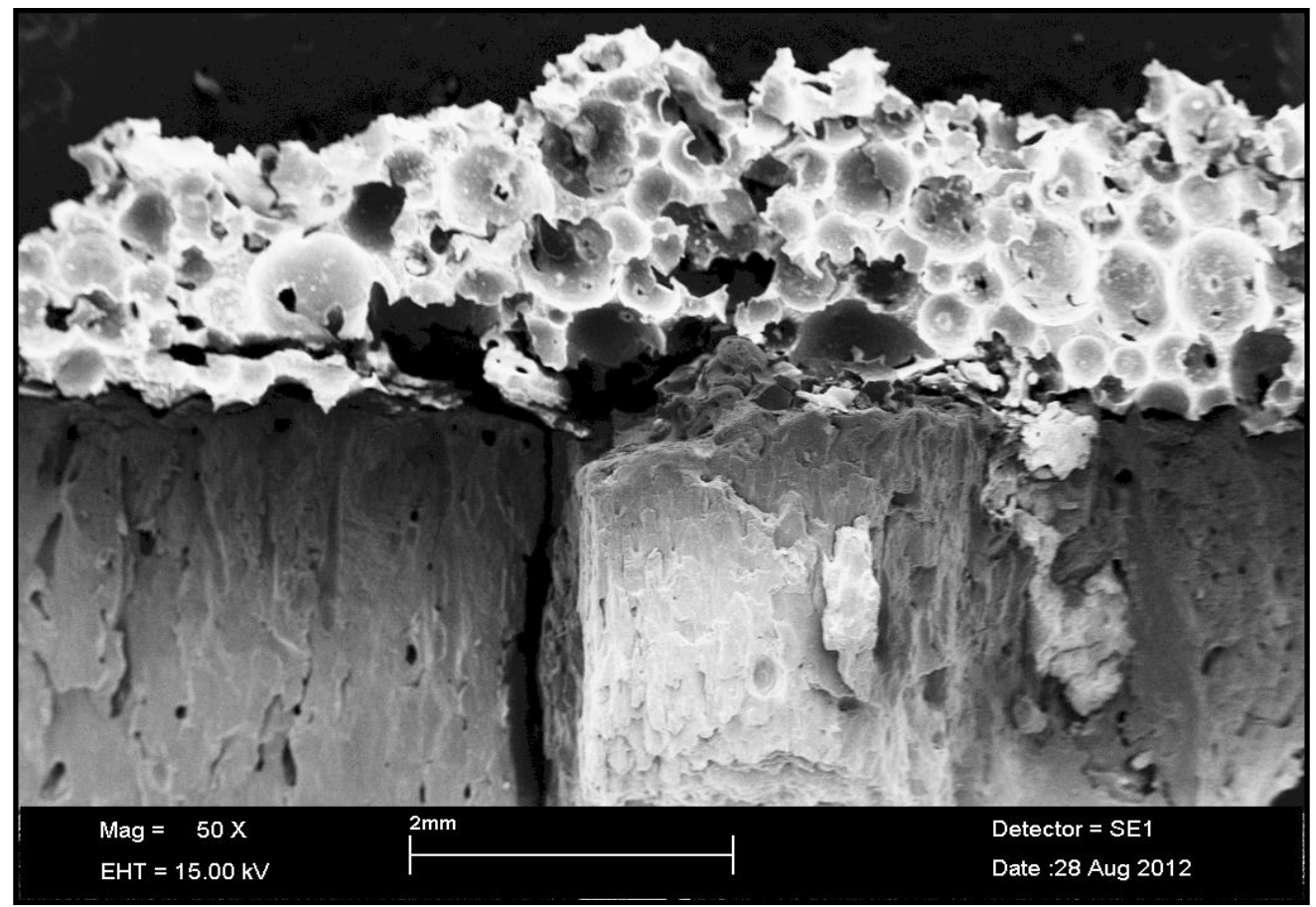

Ausência de áreas de osso neoformado.

Fonte: Selim, M. B. (2013) 
Figura 35 - Fragmentos de biópsia óssea

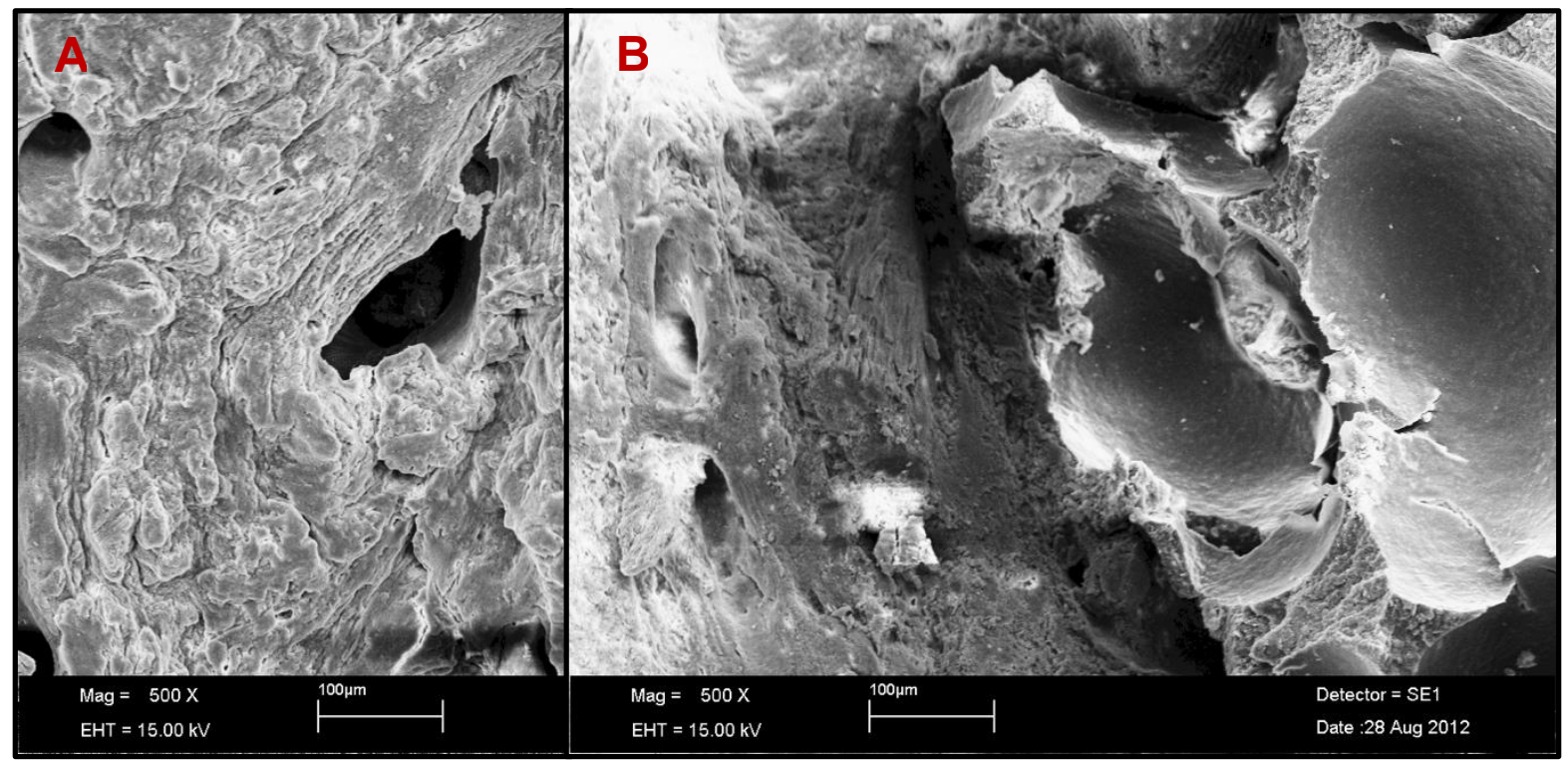

Comparação entre tecido ósseo neoformado em falha óssea na ausência $(A)$ e na presença do biomaterial (B, à esquerda). Observa-se grande semelhança estrutural.

Fonte: Selim, M. B. (2013) 


\section{DISCUSSÃO}

De acordo com Dalapicula (2006) e Lichte et al. (2011), o substituto ósseo ideal deve manter a estabilidade mecânica e o volume tecidual durante as fases iniciais da cicatrização óssea; apresentar propriedades mecânicas similares às do osso receptor; ser absorvido (biodegradável) e progressivamente substituído por novo osso; possuir superfície mimética à do osso, ou seja, microestrutura porosa que possibilite a penetração do tecido em crescimento; taxa de reabsorção igual ou semelhante à de deposição óssea; gerar produtos de degradação atóxicos e de fácil eliminação pelo organismo; e ser resistente a processos de esterilização.

Levando em consideração os pré-requisitos citados, optou-se por estudar a interação do polímero à base de poliuretana de mamona com o tecido ósseo equino, pois este material demonstrou ser uma opção viável de substituto ósseo nesta espécie, uma vez que, segundo Jacques et al. (2004); Ignácio (1995); Bolson et al. (2005); Maria, Padilha Filho e Castro, (2003) e Leonel et al. (2003) ele apresenta: compatibilidade com os tecidos vivos, atoxicidade, flexibilidade de formulação, facilidade de manipulação, bom poder de adesão ao tecido receptor, baixa temperatura de polimerização, não emissão de vapores tóxicos durante a polimerização, excelentes propriedades estruturais (presença de poros irregulares), resistência mecânica similar à do osso humano, atividade osteocondutora e bactericida, além de baixo custo.

A escolha do polímero a base de poliuretna de mamona foi baseada em todas as suas características físico-químicas e na necessidade de se adotar novas estratégias para aumentar as taxas de sucesso no tratamento de fraturas em equinos.

Considerando os estudos apresentados no item 3.4.4 Os substitutos ósseos em ortopedia de equinos, constatou-se que os métodos de avaliação da compatibilidade e eficiência dos materiais implantados sempre incluem a avaliação clínica dos animais associada a técnicas de diagnóstico por imagem. Na maioria dos estudos estes métodos foram complementados com a análise histopatológica para determinar se houve a formação de tecido ósseo, efetuar a sua quantificação e avaliação qualitativa. Em alguns estudos também foram empregadas técnicas como a micro tomografia computadorizada para a determinação do volume e densidade do 
osso neoformado; quantificação do teor de cinzas, de cálcio e a avaliação biomecânica dos fragmentos ósseos.

Com base nestas informações optou-se, neste experimento, pelos seguintes métodos de avaliação: exame físico e de claudicação dos animais, estudo radiográfico para determinação da densidade óssea e análise histológica por MEV e por MOL.

O exame físico possibilitou o acompanhamento global da resposta dos animais frente à implantação do biopolímero e não evidenciou a ocorrência de reações inflamatórias locais e/ou sistêmicas decorrentes da sua presença.

A partir da avaliação de claudicação buscou-se complementar as observações do exame físico e detectar alterações locomotoras deletérias nos animais. No entanto, não foi possível associar a ocorrência de claudicação de graus 1 a 3 à utilização polímero, uma vez que esta condição foi também observada nos membros não preenchidos.

Desta forma, é possível afirmar que durante todo o estudo não foram observadas alterações clínicas associadas especificamente ao biomaterial implantado.

Em estudo semelhante, Dornbusch et al. (2010) avaliou clinica e radiograficamente equinos que receberam implante a base de poliuretana de mamona em falhas ósseas induzidas na porção distal lateral do rádio. Os animais avaliados não apresentaram alterações clínicas associadas aos implantes. Observou-se apenas edema mais acentuado nos membros que receberam 0 polímero. Assim como no atual estudo, foi detectada claudicação bilateral leve após o procedimento cirúrgico, a qual não estava associada ao biomaterial estudado.

Os trabalhos de Perrier et al. (2008); Varanda (2012); Pyles et al. (2007) e Cohen et al. (2012) avaliaram os efeitos de diversos substitutos ósseos em diferentes regiões dos membros locomotores de equinos e também não detectaram claudicação associada a implantação dos biomateriais, demonstrando que os mesmos não desencadearam processos inflamatórios capazes de prejudicar a locomoção dos animais. No estudo conduzido por Pyles et al. (2007), observou-se, inclusive, menor grau de claudicação nos membros que receberam os implantes, o que demonstra seu alto de grau de compatibilidade com o tecido ósseo equino, além de uma ótima capacidade de estabilização da lesão. 
Considerando os estudo em que os biomateriais não foram implantados no aparato locomotor de equinos (Kawcak et al., 2000; Vlaminck et al., 2008 e Ribeiro, 2003), mas sim na cavidade oral e no gradil costal, também não foram observadas alterações clínicas e/ou funcionais relacionadas aos implantes.

O esquema proposto para o acompanhamento radiográfico visou monitorar a evolução da reparação óssea, a estabilidade dos implantes no leito receptor e a possível ocorrência reações de incopatibilidade biológica ao material. De acordo com os resultados obtidos, não observou-se deslocamento aparente dos implantes nem reações de osteólise e/ou proliferação óssea acentuadas nas áreas adjacentes ao biomaterial, indicando que o mesmo apresentou biocompatibilidade com o tecido ósseo equino. No entanto, notou-se menor velocidade de preenchimento ósseo das falhas tratadas com o polímero.Todas as publicações utilizadas como referência da utilização de biomateriais em ortopedia equina realizaram o acompanhamento radiográfico dos animais. Nos trabalhos de Ribeiro (2003) e Dornbusch et al. (2010), nos quais também foi implantada a poliuretana a base de mamona no tecido ósseo equino, obteve-se resultados contrastantes.

Analogamente ao presente estudo, Dornbusch et al. (2010) não detectaram sinais de incompatibilidade do material no preenchimento de falhas ósseas induzidas no rádio de cavalos. Também foi observada menor velocidade de preenchimento das falhas que receberam o biomaterial.

No entanto, Ribeiro (2003), ao utilizar a poliuretana a base de mamona para preencher alvéolos dentários de equinos após exodontia, detectou aumento da radiopacidade local e proliferação óssea acentuada nos sítios de implante e adjascências 120 após a implantação. As respostas antagônicas ao mesmo material podem dever-se a sua implantação ter ocorrido em regiões anatômicas distintas. Nos dois primeiros casos o material foi implantado em ossos longos, os quais possuem mesma origem embriológica. Portanto, é de se esperar que o tecido apresente comportamento similar a um determinado material, ainda que tenham havido diferenças no seu método de aplicação. No segundo caso, o polímero foi implantado no tecido ósseo da cavidade oral, o qual possui origem embriológica diferente do esqueleto apendicular; e apresenta tendência a maior responsividade nos processos de reparação devido às suas particularidades.

Pyles (2007); Perrier et al. (2008) e Varanda (2012) concluíram que houve maior e melhor preenchimento das lesões tratadas com os substitutos ósseos 
estudados em cada caso. No entanto Kawcak et al. (2000) e Cohen (2012), não constataram diferença significativa na repração das lesões ósseas na presença dos biomateriais avaliados.

Assim como neste trabalho, nenhum dos estudos citados apresentou evidências radiográficas de incompatibilidade aos biomateriais implantados.

O monitoramento da densidade óssea durante o processo de reparação possibilitou a quantificação e comparação deste processo na presença e na ausência do biopolímero. Além disso, objetivou avaliar a qualidade do tecido ósseo neoformado, pois sabe-se que a densidade do tecido ósseo está intimamente relacionada à sua resistência mecânica.

Os resultados da avaliação densitométrica revelaram que a densidade óssea não retornou aos valores originais na presença do polímero dentro do período de estudo (120 dias), diferentemenete do observado no grupo controle. No entanto, não é possível afirmar que este fenômeno não possa ocorrer em uma fase mais tardia da reparação óssea. Tal hipótese não é descartada, porque de acordo com a análise das mensurações radiográficas de diâmetros (tranversal e longitudinal), área e profundidade, comprovou-se que a reparação das falhas do grupo polímero é mais lenta que a do grupo controle.

Portanto, não foi possível verificar se a qualidade de tecido ósseo formado na presença do polímero foi preservada através do monitoramento da densidade óssea.

A densitometria óssea também foi monitorada por Kawcak et al. (2000); Vlaminck et al. (2008) e Varanda (2012), após a implantação de substitutos ósseos em equinos. Varanda (2012) verificou ao final de seu estudo que a densidade óssea do grupo tratado com células tronco foi superior à do grupo controle. No entanto, não foi registrado o valor inicial da densidade óssea dos animais utilizados, antes da indução das falhas ósseas, não sendo possível esclarecer se a mesma tendeu a retorornar aos valores originais. Portanto, não é possível afirmar que a qualidade do tecido ósseo neoformado após a aplicação de células tronco foi mantida.

De acordo com Kawcak et al. (2000), não foi observada diferença estatisticamente significativa entre a densidade entre o grupo controle e os tratados com enxerto autólogo esponjoso ou matriz óssea mineralizada, embora o grupo tratado com o enxerto autólogo tenha apresentado a maior média em relação aos demais. Os autores devem este achado ao maior teor de cálcio presente nas lesões preenchidas com este material, pois trata-se de um composto mineralizado. 
Vlaminck et al. (2008) detectaram menor valor médio de densidade nos animais que receberam o substituto ósseo, porém muito próximo ao do grupo controle. Além disso, não houve significância estatística entre os grupos; ou seja, a resposta do organismo na presença do substituto ósseo foi similar à fisiológica.

A avaliação por MEV permitiu a observação da microestrutura óssea, revelando se a mesma foi preservada durante o processo de reparação na presença do biomaterial. Este é um dos aspectos mais importantes do estudo, pois o rearranjo da estrutura óssea pode comprometer as suas características biomecânicas, e, consequentemente, a sua capacidade de suportar cargas.

Considerando os achados da MEV, foi possível preencher a lacuna deixada pela densitometria óssea no que diz respeito à qualidade óssea, pois a partir dela comprovou-se que a microestrutura do osso neoformado na presença do biomaterial assemelha-se muito à observada nas biópsias do grupo controle e nos fragmentos de tecido obtidos durante a confecção das falhas ósseas.

Além disso, não foi detectada a formação de tecido cicatricial no grupo preenchido por polímero, sendo observado apenas tecido ósseo imaturo, ainda que em pequena quantidade. Tais observações são positivas, pois demonstram que o biomaterial não induz reações de corpo entranho e que tende a ser substituído por tecido ósseo de qualidade equivalente à inicial.

Outro aspecto avaliado através da MEV foi a estrutura do biomaterial após a interação com o tecido ósseo. Observou-se sinais discretos de degradação do polímero, sendo que a sua estrutura apresentava-se ainda bastante preservada 120 após a implantação. Este achado sugere que o material apresentou comportamento bioabsorvível na espécie equina; contudo, a velocidade de absorção é evidentemente menor do que a de formação do tecido novo, sendo este o provável fator que prolongou o tempo de preenchimento das falhas ósseas observado no estudo.

Nenhum dos artigos utilizados como referência empregou a microscopia eletrônica de varredura para avaliar a interação entre os materiais implantados e o tecido ósseo de equinos. Efetuou-se nova pesquisa às bases de dados científicos e não foram encontradas publicações que utilizaram a MEV para a avaliação do tecido ósseo equino. Portanto, não foi possível confrontar os resultados obtidos neste estudo com outros desenvolvidos previamente envolvendo a espécie equina. 
No entanto, foram encontrados estudos que empregaram a MEV como método de avaliação do tecido ósseo de coelhos, ratos e humanos após a implantação de substitutos ósseos. Tais artigos serão apresentados a seguir e terão seus resultados comparados ao deste trabalho.

Fellah et al. (2006) implantaram biomaterial a base de polímero e fosfato de cálcio bifásico em defeitos críticos induzidos nas epífises distais do fêmur de coelhos e efetuaram avaliação dos sítios de implante por MEV após oito semanas de interação. Foi observado tecido ósseo mineralizado de aspecto maduro em contato com a superfície dos implantes e em seu interior. Tal osso apresentava padrão trabeculado delgado, em aposição direta sobre os grânulos de fosfato de cálcio, sem a presença de tecido fibroso na interface. Os autores concluíram que o biomaterial promoveu reparação óssea satifatória, apresentando ótima osteocondutividade e recomendaram o seu emprego na rotina de procedimentos ortopédicos para 0 preenchimento de defeitos críticos.

Em um estudo envolvendo a implantação biomaterial a base de hidroxiapatita na tíbia de coelhos, Chang et al. (2000) utilizaram a MEV para avaliar a responsividade do tecido ósseo à 3 diferentes configurações de porosidade do material. A primeira delas tratava-se de cilindros com poros lineares e paralelos, a segunda de uma esponja com poros conectados irregularmente e a terceira possuía padrão de porosidade cruzado. Constatou-se que na presença dos cilindros de porosidade regular foi formado tecido ósseo organizado paralelamente ao eixo longo dos poros, havendo forte união entre o implante e o osso, sem a presença de lacunas. Notou-se substituição do material por osso lamelar, com a presença de vasos sanguíneos em arranjo similar a canais de Volkmann.

No caso do material esponjoso, observou-se a formação de tecido ósseo de padrão irregular por entre seus poros. Já no padrão cruzado, o tecido neoformado apresentava padrão intermediário entre os observados nos cilindros e na esponja com poros irregulares. Os autores concluíram que o padrão estrutural do osso neoformado está intimamente relacionado à conformação do implante, mais especificamente no que diz respeito à sua porosidade.

Matsuda et al. (1995) compararam através da MEV a resposta do tecido ósseo da calvária de ratos a dois implantes distintos: um derivado de osso natural sinterizado e um composto sintético a base de hidroxiapatita. Foram estudadas amostras de diversos momentos pós-operatórios (1, 2, 3 e 5 semanas), as quais 
demonstraram que na presença do osso natural ocorre uma incorporação gradativa do material, o qual ao final do experimento funde-se completamente ao osso neoformado. Contudo, na presença do substituto sintético, apesar de ocorrer a formação de osso novo na superfície do implante, não observou-se a fusão entre os dois. Ocorreu menor invasão dos poros do material por tecido ósseo. Ou seja, este implante demonstrou menor osteocondutividade que o anterior.

Em estudo envolvendo humanos, Orsini et al. (2005) avaliaram a interface entre o tecido receptor e um enxerto a base de matriz óssea bovina mineralizada após 6 meses de interação. Nos espécimes avaliados foi possível observar tecido ósseo neoformado em diversos estágios da reparação, desde de áreas preenchidas com fibrilas colágenas até outras contendo osso compacto de aspecto lamelar. No interior do material foi encontrado tecido amorfo desorganizado contendo lacunas de osteócitos vazias. De acordo com os autores, as partículas do material implantado não interferiram no processo de reparação fisiológico, além de promover a formação de osso novo.

À semelhança deste estudo, as publicações citadas buscaram descrever a interação entre os implantes e o leito receptor ao nível estrutural, sempre considerando aspectos como a adesão e incorporação do material, indução da deposição óssea e sua magnitude, além da organização do tecido neoformado.

Da mesma maneira que a poliuretana a base de mamona, todos os materiais avaliados não promoveram formação de tecido cicatricial, nem reação de corpo estranho (incompatibilidade), além de terem estimulado a formação de tecido ósseo com a preservação das características estruturais do osso original. Diferentemente da hidroxiapatita sintética de Matsuda et al. (1995) e da poliuretana, todos materiais demonstraram alta capacidade de osteocondução, tendo seu interior invadido por tecido ósseo em formação.

Assim como na MEV, a avaliação por MOL também permitiu a observação da microestrutura óssea, confirmando que o tecido neoformado na presença do material foi semelhante ao formado em condições fisiológicas. Foram observadas áreas de tecido ósseo primário em interface com resquícios do biomaterial e uma faixa de tecido secundário pré-existente.

Por outro lado, a MOL permitiu a detecção de áreas sugestivas da invasão da matriz polimérica por osso recém formado; associadas a pequenos sequestros semelhantes a fragmentos do biomaterial em meio à nova matriz óssea. Tais 
achados permitem sugerir que a poliuretana a base de mamona apresentou comportamento osteocondutor em contato com o osso equino, ainda que discreto.

Além disso, esta técnica permitiu a quantificação e comparação da taxa de reparação óssea em ambas as situações. A mensuração das áreas de tecido ósseo neoformado e pré-existente revelou uma menor proporção no grupo preenchido com o biopolímero a base de mamona. Estes resultados estão em acordo com o observado nas demais avaliações, as quais mostraram que as falhas preenchidas com biomaterial tendem a ser lentamente reparadas em comparação com as não preenchidas.

Considerando as avaliações por MOL feitas nos trabalhos de Kawcak et al. (2000); Peerier et al. (2008) e Vlaminck et al. (2008), todas demonstraram que ocorreu maior formação de tecido ósseo nos grupos que receberam os biomateriais. Apenas Cohen et al. (2012) não encontrou diferença significativa entre o preenchimento dos grupos controle e tratado.

Apesar da maioria das publicações apresentar aumento da deposição óssea associada a implantação dos substitutos ósseos, não foram feitas grandes considerações a respeito da qualidade do tecido ósseo neoformado, diferentemente deste estudo, no qual o foco foi a análise da qualidade óssea baseada em sua morfologia.

Em suma, o conjunto de avaliações permitiu estudar o comportamento do tecido ósseo equino frente ao biopolímero a base de mamona, com ênfase em sua estrutura, uma vez que somente estimulação da reparação óssea não se demonstra suficiente, sendo necessária também a preservação da qualidade do tecido e de suas caraterísticas biomecânicas.

Dessa forma, o estudo permitiu a discussão a respeito do mecanismo de ação da poliuretana de mamona sobre o do tecido ósseo equino (se osteoconduor, osteoindutor ou osteogênico), bem como de seu comportamento biológico em contato com o mesmo (se bioinerte, biotolerável, bioativo ou bioabsorvível), possibilitando responder se este se demonstrou adequado e viável para a utilização como nova ferramenta na rotina de procedimentos ortopédicos na espécie. 


\section{CONCLUSÃO}

Apesar da poliuretana a base de mamona não ter demonstrado indícios de acelerar a reparação de lesões ósseas induzidas em equinos, observou-se a preservação da estrutura do tecido ósseo na sua presença, levando à conclusão de que a qualidade do tecido neoformado é a mesma do pré-existente à sua implantação.

Além disso, o biomaterial apresentou atividade osteocondutora discreta e comportamento bioabsorvível e biocompatível com o tecido ósseo de equinos, não levando à ocorrência de reações inflamatórias acentuadas ou de corpo estranho; nem à formação de tecido cicatricial de qualidade inferior à do tecido original.

De acordo com tais afirmações, este biomaterial pode ser considerado viável como alternativa de preenchimento nos quadros de grandes perdas ósseas decorrentes de fraturas em equinos.

No entanto, sugere-se estudos a respeito de sua associação a células osteoprogenitoras e/ou mediadores celulares para incrementar a sua propriedade de osteocondução com mecanismos de osteogênese e osteoindução, podendo, assim, otimizar a reparação de fraturas em equinos. 


\section{REFERÊNCIAS}

- ADAMS, J. E. Radiogrammetry and radiographic absorptiometry. Radiologic Clinics of North America, v. 48, p. 531-540, 2010

- AFONSO, A. S. Interação entre biomateriais e tecido ósseo. Porto: Faculdade de Medicina Dentária da Universidade do Porto, 1998. 213 p. Dissertação (Doutorado) - Pós-Graduação em Medicina Dentária, Faculdade de Medicina Dentária, Universidade do Porto, Porto, 1998.

- ALVES, J. D. S.; STERMAN, F. A. Determinação da densidade mineral óssea da extremidade distal do rádio de cães da raça Rottweiler, por meio da densitometria óptica radiográfica. Veterinária e Zootecnia, v.17, n.1, p. 229-237,2010

- ARANA, V.; BRADASCHIA, V. Tecido Ósseo. ARANA, V.; BRADASCHIA, V. In: Biologia celular e tecidual para odontologia: moléculas, células e tecidos. Rio de Janeiro: Elsevier, 2012. Cap. 11, p. 219-126.

- ARANA, V.; KATCHBURIAN, E. Tecido ósseo. ARANA, V.; KATCHBURIAN, E. In: Histologia e embriologia oral. Texto - Atlas - Correlações Clínicas. Rio de Janeiro: Guanabara Koogan, 2004. Cap. 3, p. 37-74.

- BANKS, W. J. Tecidos de Sustentação - Osso. In: Histologia Veterinária Aplicada. São Paulo: Manole, 1991. cap. 9, p. 137 - 166.

- BANKS, W. J. Osteogênese. In: Histologia Veterinária Aplicada. São Paulo: Manole, 1991. cap. 10, p. $167-186$.

- BEDZIN'SKI, R.; KRZAK-ROS', J.; STEFAN'SKA, M.; MARUSZEWSK, K. Investigation of the bone tissue and implant surface interactions. Strain, v. 46, p. 518-525, 2010.

- BERTONE, A. L. Metacarpo e Metatarso. Fraturas do Osso Metacárpico/ Metatársico Terceiro (Canela). In: STASHAK, T. S. Claudicação em Equinos Segundo Adams. São Paulo: Roca, 2006. cap. 8, pt. IV, p. 761-766.

- BOLSON, J.; SCHOSSLER, J. E.; ORNES, R. C.; MOTTIN, V.; ALBERTI, T. Análise clínica, radiológica, macroscópica e histológica do úmero de codornas domésticas (Coturnixjaponica), submetido ao implante da poliuretana derivada do 
polímero de mamona (Ricinnuscommunis). Ciência Rural, v.35, n.5, p. 11231130, 2005.

- BOUXSEIN, M. L. Bone quality: where do we go from here?Osteoporosis International, v. 14(5), p. 118-127, 2003.

- CARTER, D. R.; SPENGLER, D. M. Biomechanics of fracture. In: SUMNERSMITH G. Bone in Clinical Orthopedic, $2^{\text {nd }}$ ed., Dübendorf: AO Publishing, , 2002. p. 305-335.

- CHANG, B-S; LEE, C-K; HONG, K-S; YOUN, H-J; RYU, H-S; CHUNG, S-S; PARK, K-W. Osteoconduction at porous hydroxyapatite with various pore configurations. Biomaterials, v. 21, p. 1291-1298, 2000.

- COHEN, J. M.; SOUTHWOOD, L. L.; ENGILES, J.; LEITCH, M.; NUNAMAKER, D. M. Effects of a novel hydrogel on equine bone healing: A pilot study. Veterinary and Comparative Orthopaedics and Traumatology, v. 25, n. 3, p.184-191, 2012.

- COMPSTON, J. Bone quality: what is it and how is it measured? Arquivos Brasileiros de Endocrinologia e Metabologia, v. 50, n. 4, p.579-585, 2006.

- DALAPICULA, S. S.; VIDIGAL JUNIOR, G. M.; CONZ, M. B.; CARDOSO, E. S. Características físico-químicas dos biomateriais utilizados em enxertias ósseas. Uma revisão crítica. Implant News, v. 3, n. 5, p. 487-491, 2006.

- DAMIEN, C.; PARSONS, J. Bone graft and bone graft substitutes: A review of current technology and applications. Journal of Applied Biomaterials, v. 2, n. 3, p. $187-208,1991$.

- DEMPSTER, D. W.; LINDSAY, R. A method for correlative light microscopy (LM) and scanning electron microscopy (SEM) of human iliac crest bone biopsies. Bone, v. 6, n. 5, p. 416, 1985.

- DORNBUSCH, P. T.; ARAUJO, I. G. R; TASQUETTI, U. Y.; PIMPÃO, C. T.; PRADO, A. M. B.; HUSSNI, C. A. Avaliação radiográfica da aplicação do polímero de mamona em falhas ósseas induzidas em equinos. Archives of Veterinary Science, v 15, n. 1, p. 1-8, 2010. 
- FELLAH, B. H.; WEISS,P.; GAUTHIER, O.; ROUILLON,T.; PILET, P.; DACULSI, G.; LAYROLLE. P. Bone Repair Using a New Injectable Self-Crosslinkable Bone Substitute. Journal of Orthopaedic Research, v. 24, n. 4, p. 628-635, 2006.

- FELSENBERG, D.; BOONEN, S. The bone quality framework: determinants of bone strength and their interrelationships, and implications for osteoporosis management. Clinical Therapeutics, v. 27, n. 1, p.1-11, 2005.

- FONSECA, A. A. R. Avaliação do efeito da formalina na descalcificação de espécimes anatômicos, por meio da densidade radiográfica e concentração de cálcio, 2007, 98 p. Tese (Doutorado) - Programa de Pós-Graduação em Odontologia, Faculdade de Odontologia, Pontifícia Universidade Católica do Rio Grande do Sul, Porto Alegre, 2007.

- FRAZÃO, P. J. R.; CRISPIM, R.; PEREIRA, C. A. M.; SELIM, M. B.; FACÓ, L. L.; PINTO, A. C. B. C. F; HAGEN, S. C. F.; ZOPPA, A. L. V. Correlation study between bone mineral density determined by radiographic absorptiometry and bone resistance of equine third metacarpal bone submitted to biomechanical testing. Journal of Musculoskeletal Research, v. 15, n. 1, p. 1250007-1 1250007-8, 2012.

- GALANTE, J. O.; LEMONS, J.; SPECTOR, M.; WILSON, P. D.; WRIGHT, T. M. The biologic effects of implant materials. Journal of Orthopaedic Research, v. 9, n. 5, p. 760-775, 1991.

- GUERRA, P. C.; VULCANO, L. C.; ROCHA, N. S. Avaliação radiográfica, densitométrica e histológica do uso de perfurações ósseas para o estímulo de consolidação de fraturas do terço distal do rádio de cães. Brazilian Journal of Veterinary Research and Animal Science, v. 43, n. 2, p.186-195, 2006.

- GUTIERRES, M.; LOPES, M. A.; HUSSAIN, N. S.; CABRAL, A. T.; SANTOS, L. A. J. D. Substitutos ósseos conceitos gerais e estado actual. Arquivos de Medicina, v. 19, n. 4, p. 153-162, 2006.

- HAJE, D. P.; THOMAZINI, J. A.; VOLPON, J. B. Efeitos do processamento químico, da esterilização em óxido de etileno e da usinagem em parafusos de osso bovino: estudo com microscopia eletrônica de varredura. Revista Brasileira de Ortopedia, v. 42, n. 4, p. 120-124, 2007.

- HERNANDES, L.; RAMOS, A. L.; MICHELETTI, K. R.; SANTI, A. P.; CUOGHI, O. A.; SALAZAR, M. Densitometry, radiography, and histological assessment of 
collagen as methods to evaluate femoral bones in an experimental model of osteoporosis. Osteoporosis International, v. 23, n. 2, p. 467-473, 2012.

- HIGASHI, S.; YAMAMURO, T.; NAKAMURA, T.; IKADA, Y.; HYON, S. H.; JAMSHIDI, K. Polymer-hydroxyapatite composites for biodegradable bone fillers. Biomaterials, v.7, n. 3, p. 183-187, 1986.

- HOLLINGER, J. O.; BUCK, D.; SCHMITZ, J. P. Quantitative light microscopy. A powerful tool to access bone. Clinical Plastic Surgery, v. 21, n. 3, p. 463-475, 1994.

- IGNACIO, H. ; MAZZER, N. ; BARBIERI, C. H. ; CHIERICE, G. O. Estudos sobre a aplicabilidade médica da poliuretana derivada da mamona. Resenha Ortopédica, v. 6, p.10-12, 1996.

- ITO, K.; PERREN, S. M. Biologia e biomecânica da consolidação óssea. RÜEDI, T. P.; BUCKLEY, R. E.; MORAN, C. G. In: Princípios AO do tratamento de fraturas. Porto Alegre: Artmed, 2009. Cap. 1, p. 33-55.

- JACQUES, J. W.; FAGUNDES, D. J. ; FIGUEIREDO, A. S.; INOUYE, C. M.; SCAPULATEMPO, R. P.; SASSIOTO, M. C. P. O papel da poliuretana de mamona como substituto do enxerto ósseo autógeno em coelhos. Revista do Colégio Brasileiro de Cirurgiões, v. 31, n. 4, p. 236-241, 2004.

- KAWCAK, C. E.; TROTTER, G. W.; POWERS, B. E.; PARK, R. D.; SIMON TURNER, A. Comparison of bone healing by demineralized bone matrix and autogenous cancellous bone in horses. Veterinary Surgery, v. 29, p.218-226, 2000.

- KAWACHI, E. Y.; BERTRAN, C. A.; REIS, R. R.; ALVES, O. L. Biocerâmicas: tendências e perspectivas de uma área interdisciplinar. Química Nova, v. 23, n. 4, p. 518-522, 2000.

- KÖNIG, H. E.; LIEBICH, H-G. Introdução. Sistema Esquelético. Estudo dos ossos. In: Anatomia dos Animais Domésticos. Porto Alegre: Artmed, 2002. p. 4-14.

- LEONEL, E. C. F.;MANGILLI, P. D.;RAMALHO, L. T. O.;H.F.; SOBRINHO, J. A. A importância da porosidade interna do polímero de mamona durante a neoformação óssea - Estudo em ratos. Ciência Odontológica Brasileira, v. 6, n. 3, p.19-25, 2003. 
- LEONEL, E. C. F.; PORCIÚNCULA, H.F.; SOBRINHO, J. A.; RAMALHO, L. T. O.; MANGILLI, P. D.; RAPOPORT, A.. A ação do polímero de mamona durante a neoformação óssea. Acta Cirúrgica Brasileira, v. 19, n. 4, p.342-350, 2004.

- LI, J. C.; HUANG, B. L.; XU, Z. Q. Current situation and progress of bone histomorphometry studies in clinical bone diseases. Journal of Clinical Rehabilitative Tissue Engineering Research, v. 15, n. 35, p. 6607-6610, 2011.

- LICHTE, P.; PAPE, H. C.; PUFE, T.; KOBBE, P.; FISCHER, H. Scaffolds for bone healing: concepts, materials and evidence. International Journal of the Care of the Injure, v. 42, n. 6, p.569-573, 2011.

- LOPEZ, M.; MARKEL, M. D. Bone biology and fracture healing. In: AUER, J. A.; STICK, J. A. Equine Surgery. Philadelphia: W.B. Saunders Co, 2006. chap. 80, p.991-1000.

- LOPEZ, M.; MARKEL, M. D. Bone biology and fracture healing. In: AUER, J. A.; STICK, J. A. Equine Surgery. Philadelphia: W.B. Saunders Co, 2012. chap. 74, p.1025-1039.

- MARIA, P. P.; PADILHA FILHO, J. G.; CASTRO, M. B. Macroscopic and histopathologic evaluations of the use of polyurethane resins derived from castor oil (Ricinus communis) applied in the tibia of the puppies. Acta Cirúrgica Brasileira, v. 18, n. 4, p. 332-336, 2003.

- MARKEL, M. D. Bone structure and the responde of bone to stress. In: Equine Fracture Repair. Philadelphia: W.B. Saunders Co, 1996. chap. 1, p. 10-18.

- MARKS JR.; S. C.; CIELINSKI, M. J.; SUNDQUIST, K. T. Bone surface morphology reflects local skeletal metabolism. Microscopy Research and Technique, v. 33, p. 121-127, 1996.

- MARTIN, R. M.; CORREA, P. H. S. Bone quality and osteoporosis therapy. Arquivos Brasileiros de Endocrinologia e Metabologia, v. 54, n. 2, p. 186-199, 2010.

- MATSUDA, M.; KITA, S.; TAKEKAWA, M.; OHTSUBO, S.; TSUYAMA, K. Scanning electron and light microscopic observations on the healing process after sintered bone implantation in rats. Histology and Histopathology, v. 10, p. 673679, 1995. 
- MORAES, P. C.; PADILHA FILHO, J. G.; CANOLA, J. C.; SANTOS, L. A.; MACORIS, D. G.; ALESSI, A. C.;CASTRO, M. B.; DÓRIA NETO, F. A. Biocompatibilidade do cimento de fosfato de cálcio implantado no rádio de coelhos. Acta Cirúrgica Brasileira, v. 19, n. 4, p. 351-359, 2004.

- MORAES, S. Tecido ósseo in: JUNQUEIRA, L. C. U.; CARNEIRO, J. Histologia Básica. Rio de Janeiro: Guanabara Koogan, 2008. cap. 8, p. 135-152.

- NUSS, K. M. R.; VON RECHENBERG, B. Biocompatibility issues with modern implants in bone - A review for clinical orthopedics. The Open Orthopaedics Journal, v. 2, p. 66-78, 2008.

- ORSINI, G.; TRAINI, T.; SCARANO, A.; DEGIDI, M.; PERROTTI, V.; PICCIRILLI, M.; PIATTELLI, A. Maxillary Sinus Augmentation with Bio-Oss Particles: A Light, Scanning, and Transmission Electron Microscopy Study in Man. Journal of Biomedical Materials Research, v. 74B, n. 1, p. 448-457, 2005.

- PEREIRA, P. H. L. Estudo das propriedades físico-químicas da poliuretana derivada do óleo de mamona com potencial aplicação na área médica. São Carlos: USP, 2010. 75 p. Dissertação (Mestrado), Instituto de Química, Universidade de São Paulo, São Carlos, 2010.

- PÉREZ-SÁNCHEZ, M. J.; RAMÍREZ-GLINDON, E.; LLEDÓ-GIL, M.; CALVOGUIRADO, J. L.; PÉREZ-SÁNCHEZ, C. Biomaterials for bone regeneration. Materials Today, v. 11, n. 5, p. 18-25, 2008.

- PERRIER, M.; LU, Y.; NEMKE, B.; KOBAYASHI, H.; PETERSON, A.; MARKEL, $M$. Acceleration of second and sourth metatarsal fracture healing with recombinant human bone morphogenetic protein-2/calcium phosphate cement in horses. Veterinary Surgery, v. 37, p.648-655, 2008.

- PYLES, M. D.; ALVES, A. L. G.; HUSSNI, C. A.; THOMASSIAN, A.; NICOLETTI, J. L. M.; WATANABE, M. J. Parafusos bioabsorvíveis na reparação de fraturas experimentais de sesamóides proximais em equinos. Ciência Rural, v. 37, n. 5, p.1367-1373, 2007.

- RATNER, B. D.; HOFFMAN, A. S.; SCHOEN, J.; LEMONS, J. E. Biomaterials science: an envolving, multidisciplinary endeavor. RATNER, B. D.; HOFFMAN, A. S.; SCHOEN, J.; LEMONS, J. E. In: Biomaterials Science. An Introduction to Materials in Medicine. Waltham: Academic Press, 2013. cap. 1, p. 25-39. 
- RAUCH, F. Bone biopsy: indications and methods. Endocrine Development, v. 16, p. 49-57, 2009.

- RIBEIRO, M. G. Avaliação clínica e histológica do implante de poliuretana de mamona (Ricinus communis) no espaço alveolar após exodontia do terceiro pré-molar inferior: Estudo experimental em equinos. 2003, 93 p. Tese (Doutorado), Faculdade de Medicina Veterinária e Zootecnia, Universidade de São Paulo, São Paulo, 2003.

- RÍOS-DÍAZ, J.; HEVILLA, F. J. L.; MARTÍNZ-PAYÁ, J. J.; CORTÉZ, M. A. P.; DEL BAÑO ALEDO, M. E. Arquitectura y organización del hueso ante la aplicación de diferentes estímulos mecânicos. Fisioterapia, v. 30, n. 4, p.194-203, 2008.

- SAHAR, N. D.; HONG, S.; KOHN, D. H. Micro- and nano-structural analyses of damage in bone. Micron., v. 36, p. 617-629, 2005.

- SÁNCHEZ, J. C.; TRAPERO, J. C.; LAFUENTE, J. C. G.; LÓPEZ, L. A. M.; MARTÍNEZ, A. B. Undecalcified bone samples: a description of the technique and its utility based on the literature. Medicina y Patología Oral, v. 10, p. E74-E87, 2005.

- SCHWEITZER, M. H.; AVCI, R.; COLLIER, T.; GOODWIN, M; B. Microscopic, chemical and molecular methods for examining fossil preservation. Comptes Rendus Palevol, v. 7, p. 159-184, 2008.

- SELTZER, K. M.The effect of whole diameter on the torsional mechanical properties of the equine third metacarpal bone.Veterinary Surgery, v. 25, n. 5, p.371-375, 1996.

- SILVA, S. B.; FERRIGNO, C. A.; STERMAN, F. A.; BACCARIN, D. C. B.; YAKBEK, K. V. B.; MURAMOTO, C.; AMAKU, M. Plasma rico em plaquetas combinado a hidroxiapatita na formação do calo ósseo em fraturas induzidas experimentalmente no rádio de cães. Ciência Rural, v. 37, n. 4, p.1045-1051, 2007.

- SISSON, S.; GROSSMAN, J.D. Anatomia dos Animais Domésticos-Getty. Rio de Janeiro: Guanabara Koogan, 1986, v.1, p.19-267.

- VAN LIESHOUT, E. M. M.; VAN KRALINGEN, G. H.; EL-MASSOUDI, Y.; WEINANS, H.; PATKA, P. Microstructure and biomechanical characteristics of 
bone substitutes for trauma and orthopaedic surgery. BMC Musculoskeletal Disorders, v. 12, n. 34, p. 2-14, 2011.

- VARANDA, L. F. O. Células tronco mesenquimais provenientes da medula óssea na reparação de falhas ósseas experimentais no osso IV metacarpiano de equinos. 2012, 96 p. Dissertação (Mestrado) - Programa de Pós-Graduação em Saúde Animal, Faculdade de Agronomia e Medicina Veterinária, Universidade de Brasília, Brasília/DF, 2012.

- VERTENTEN, G.; GASTHUYS, F.; CORNELISSEN, M.; SCHACHT, E.; VLAMINCK, L. Enhancing bone healing and regeneration: present and future perspectives in veterinary orthopaedics. Veterinary and Comparative Orthopaedics and Traumatology, v. 23, n. 3, p. 153-162, 2010.

- VLAMINCK, L.; CNUDDE, V.; PIETERS, K.; VAN DEN BROECK, W.; STEENHAUT, M.; JACOBS, P.; GASTHUYS, F. Histologic and micro-computed tomographic evaluation of the osseointegration of a nonresorbable bone substitute in alveoli of ponies after tooth extraction. American Journal of Veterinary Research, v. 69, n. 5, p.604-610, 2008.

- VULCANO, L. C.; SANTOS, F. A. M.; GODOY, C. L. Determinação da densidade mineral óssea da extremidade distal do rádio-ulna em gatos: correlação entre peso, sexo e idade. Ciência Rural, v. 38, n. 1, p. 124-128, 2008. 


\section{APÊNDICES}

\section{Apêndice A}

Protocolo de processamento das amostras destinadas à MOL

Após a sua coleta, os fragmentos ósseos foram acondicionados em recipientes contendo fixador a base de paraformaldeído a $20 \%$ em tampão de fosfato monobásico anidro a $0,1 \mathrm{M}$ e fosfato dibásico a 0,1M. A fixação se deu por um período de 48 à temperatura ambiente. Posterioemente, os espécimes foram desidratados através da manutenção em solução de álcool a 70\% por um período de 24 horas, e 3 ciclos de imersão em solução de álcool absoluto por 24, 48 e 56 horas, respectivamente, com a troca da solução entre cada um dos ciclos.

Seguindo à desidratação, as amostras foram diafanizadas através da imersão em xilol por um período de 24 horas. Passado este período o xilol foi substituído por novo e as amostras permaneceram imersas por um período de mais 48 horas na nova solução.

Cada amostra foi, então, incluída em resina (metilmetacrilato) em frascos de vidro de aproximadamente $20 \mathrm{ml}$. Os frascos serviram como molde para a inclusão do material, tendo sido quebrados após a polimerização da resina para a obtenção dos blocos.

Cada bloco foi aparado com o auxílio de uma serra manual para que ficasse em formato de paralelepípedo e pudesse ser fixado às garras do micrótomo EXAKT BANSYSTEM 300 CP. O micrótomo produziu cortes de espessura de aproximadamente $0,5 \mathrm{~mm}$, os quais foram desgastados com lixas de carbeto de silício de granulações 320, 600, 1000, 2400 e 4000 antes de serem colados em lâminas de acrílico transparente de $2 \mathrm{~mm}$ de espessura.

Cada lâmina teve o seu respsectivo corte desgastado na mesma sequência de lixas após a colagem, com excessão da de granulação 320. Depois de prontas, as lâminas foram coradas seguindo o protocolo de coloração Stevenel's Blue:

- Manutenção das lâminas em cubeta contendo solução de Stevenel's Blue a $60^{\circ} \mathrm{C}$ por 15 minutos; 
- Lavagem das lâminas com água destilada a $60^{\circ} \mathrm{C}$ e secagem com ar;

- Pipetar pequena quantidade da solução de Alizarina Vermelha na superfície das lâminas e deixar corar por 5 minutos à temperatura ambiente;

- Enxaguar as lâminas em água destilada corrente para remover o excesso de corante e secar com ar.

Solução de Stevenel's Blue:

- Solução A:

$75 \mathrm{ml}$ de água detilada

$1,0 \mathrm{~g}$ de azul de metileno

- Solução B:

$75 \mathrm{ml}$ de água destilada

$1,5 \mathrm{~g}$ de permanganato de potássio

Misturar as soluções $A$ e $B$ e aquecer a solução final até que o precipitado se dissolva completamente. Aguarde a solução esfriar, filtre armazene.

Solução de Alizarina Vermelha:

$75 \mathrm{ml}$ de água destilada

2,0g de Alizarina Vermelha S

Diluir a Alizarina ná água destilada morna (aproximadamente a $45^{\circ} \mathrm{C}$ ), agitando sempre. Aguardar a solução esfriar, ajustar o $\mathrm{pH}$ para valores entre 4,1 e 4,3 com solução de hidróxido de amônia e armazenar. 


\section{Apêndice B}

Protocolo de processamento das amostras destinadas à MEV

Imediatamente após a coleta, as amostras foram acondicionadas em recipientes contendo fixador à base de $2 \%$ de glutaraldeído a $25 \%, 2,5 \%$ de paraformaldeído a 20\% em tampão cacodilato de sódio a 0,1M e pH 7,4.

Para acelerar a fixação as amostras foram levadas ao forno de microondas laboratorial por três ciclos de 5 minutos cada, a uma temperatura máxima de $37^{\circ} \mathrm{C}$, controlada através da imersão das amostras em banho de gelo.

Após o processamento no forno de microondas as amostras foram mantidas no fixador à temperatura ambiente por um período de 2 horas e depois levadas à geladeira por um período de 24 horas. Depois procedeu-se à lavagem das mesmas para a retirada do fixador através de 6 ciclos de rotação de 10 minutos cada em água milliQ, substituída a cada ciclo.

Depois da remoção do fixador, foi necessária a remoção do material orgânico das amostras. Para tanto, elas foram mantidas em solução de $\mathrm{NaOCl}$ (hipoclorito de sódio) em rotação por 3 horas, e depois submetidas a um ciclo de 3 minutos no aparelho de ultrassom.

A remoção da solução de hipoclorito de sódio foi feita através de 6 ciclos de lavagem em água milliQ em rotação, seguidos de dois ciclos, um de 1 e outro de 2 minutos, no aparelho de ultrassom. A água foi trocada a cada ciclo.

O próximo passo foi a desidratação das amostras através da manutenção das mesmas por cerca de 5 minutos em soluções de concentrações crescentes de etanol $(30,50,70,80,90$ e 95\%). A última etapa da desidratação consistiu na manutenção das amostras em etanol absoluto por dois ciclos de 10 minutos cada, com a troca do etanol entre eles.

Os espécimes foram então retirados da solução de etanol absoluto e colocados em contato com papel absorvente para a retirada do excesso de líquido, não sendo completamente secos. Na sequência, foram colocados em solução de HMDS por 10 minutos, por dois ciclos consecutivos, com a substituição da solução entre eles. Retirou-se os fragmentos ósseos desta solução e procedeu-se à sua secagem em papel absorvente e manutenção dos mesmos à temperatura ambiente por 48 horas para a completa secagem. 
Depois de secos, os fragmentos foram fixados a pequenos suportes de metal (stubs) com fita dupla face e submetidos à metalização com ouro sob sistema de vácuo. A observação das amostras se deu no mesmo dia em que foram metalizadas. 